JOYCE MARTINS MENDES

AVALIAÇÃO DE SERVIÇOS CONVERGENTES EM AMBIENTES
HETEROGÉNEOS

São Paulo

2007 
JOYCE MARTINS MENDES

\section{AVALIAÇÃO DE SERVIÇOS CONVERGENTES EM AMBIENTES HETEROGÊNEOS}

Tese apresentada à Escola Politécnica da Universidade de São Paulo para a obtenção do título de doutora em Engenharia.

São Paulo 
JOYCE MARTINS MENDES

\title{
AVALIAÇÃO DE SERVIÇOS CONVERGENTES EM AMBIENTES HETEROGÉNEOS
}

\author{
Tese apresentada à Escola Politécnica da Universidade \\ de São Paulo para a obtenção do título de doutora em \\ Engenharia. \\ Área de Concentração: \\ Engenharia Elétrica em Sistemas Digitais \\ Orientador: \\ Prof. Dr. Edison Spina
}

São Paulo 


\section{Ficha Catalográfica}

MENDES, Joyce Martins

Avaliação de serviços convergentes em ambientes heterogêneos. São Paulo, 2006. p.

Tese (doutorado) - Escola Politécnica da Universidade de São Paulo. Departamento de Engenharia de Computação e Sistemas Digitais.

1. Fatores Humanos, 2.. ISO 13407,.3. Interface HomemComputador, Engenharia de sistemas. I.Universidade de São Paulo.

Escola Politécnica. Departamento de Engenharia de Computação e Sistemas Diqitais 


\section{DEDICATÓRIA}

Dedico este trabalho primeiramente a Deus por mais esta benção; a meus pais Armando e Geni pelo incentivo, pois graças a eles subi mais um degrau; ao meu irmão Junior e ao meu querido Arthur pelo amor, apoio e palavras de incentivo. 


\section{AGRADECIMENTOS}

Agradeço ao Prof. Dr. Edison Spina pela orientação, apoio e paciência na realização deste trabalho. Ao Prof. Dr. Moacyr Martucci Junior pelo suporte através do projeto INSTINCT e pelo incentivo constante. A Profa Dra. Raquel Navarro pelo apoio e participação nas discussões técnicas. Ao Eng. Walter Duran e à Philips por todo suporte no projeto Voices. A Comissão Européia integrada ao INSTINCT (IST-1507017-IP-Oe) por ter patrocinado este trabalho. Agradeço também todos os colegas do Knoma - Laboratório de Engenharia de Conhecimento do PCS que, direta ou indiretamente, colaboraram nesse trabalho. 
Conceda-me a beleza interior, e que tudo o que me rodeia, esteja em paz com aquele interior. Sócrates 


\section{RESUMO}

Este trabalho propõe um modelo de avaliação da aceitabilidade de produtos, incluindo serviços, softwares, equipamentos e modelos de negócio além de um método de aplicação na avaliação de serviços convergentes em ambientes de redes heterogêneas aplicado diretamente aos usuários potenciais.Este modelo permite ainda atingir uma amostragem significativa de usuários com expressiva diversidade cultural de maneira concisa e eficaz, com baixo custo através da utilização da Web.

Palavras-chave: Fatores Humanos, ISO 13407, Interface Homem-Computador, Engenharia de sistemas. 


\begin{abstract}
"This work proposes a products acceptability evaluation model, including services, software, equipments and business models, besides an application method for convergent services evaluation in heterogeneous networks environments, applied directly to the potential users. This model allows, yet, reach an users' significant sampling with an expressive cultural diversity in a concise and effective way, with low cost through the Web utilization."
\end{abstract}

Keywords: Humans Factors, ISO 13407, Human- Computer Interaction, System Engineering 


\section{LISTA DE ABREVIATURAS E SIGLAS}

$\begin{array}{ll}\text { DEC } & \text { Digital Equipment Co. Ltd } \\ \text { HCIL } & \text { Human-Computer Interaction Lab } \\ \text { INSTINCT } & \text { IP-based Networks, Services and Termlnals for Converging sysTems } \\ \text { ISO/IEC } & \text { Software Product Quality Model } \\ \text { IST } & \text { Information Society Technologies } \\ \text { PIB } & \text { Produto Interno Bruto } \\ \text { PUE } & \text { Desempenho do usuário experiente } \\ \text { QFD } & \text { Quality Funtion Deployment } \\ \text { QFDr } & \text { Desdobramento da função qualidade no sentido restrito } \\ \text { QUIS } & \text { Questionnaire for User Interaction Satisfaction } \\ \text { SUS } & \text { System Usabilit Scale } \\ \text { SMS } & \text { Short Message Service } \\ \text { TARP } & \text { Technical Assistent Research Program } \\ \text { UBTs } & \text { Unidades básicas de trabalho } \\ \text { ViYH } & \text { Voices in Your Hands }\end{array}$




\section{LISTA DE FIGURAS}

Figura 1 - Fronteiras da Ergonomia, Ciência e Tecnologia: Projetos Ergonômicos ..20

Figura 2 - Qualidade percebida do serviço......................................................22

Figura 3 - Fatores de influência na formação da expectativa do cliente...................25

Figura 4 - Faixa de expectativa .................................................................2

Figura 5 - Zona de tolerância ou aceitabilidade ..............................................28

Figura 6 - O triângulo dos serviços................................................................29

Figura 7 - Dimensões de qualidade de serviços segundo Gronroos .........................30

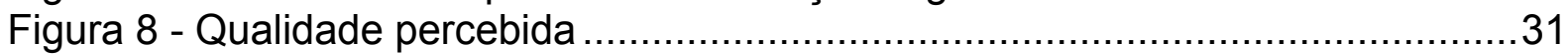

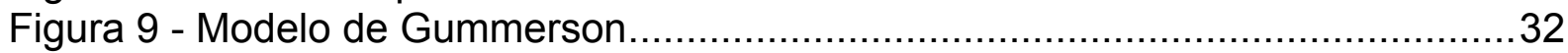

Figura 10 - Modelo de Gronroos e Gummerson ...................................................

Figura 11 - Pirâmide de Maslow......................................................................40

Figura 12 - Modelo de atributos de aceitabilidade de um sistema segundo Shackel 46

Figura 13 - Modelo de atributos de aceitabilidade de um sistema segundo Nielsen .47

Figura 14 - Modelo de medida da usabilidade segundo Nielsen .............................48

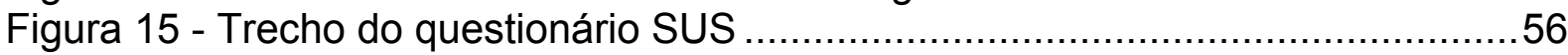

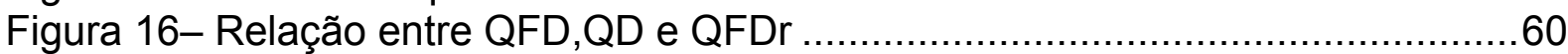

Figura 17 - Representação de uma matriz com seus elementos constituintes .........62

Figura 18 - Exemplo de uma matriz da qualidade ..........................................63

Figura 19- Modelo conceitual para definir matrizes ..............................................64

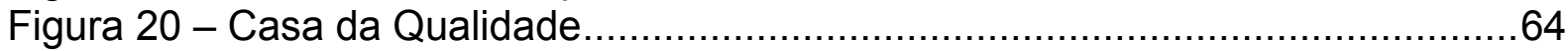

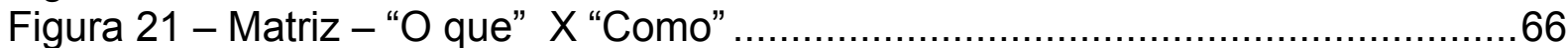

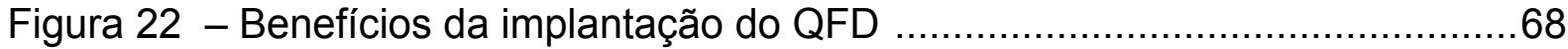

Figura 23 - Ambiente convergente …………….......................................

Figura 24 - Processo de Construção de Cenários....................................................75

Figura 25 - Seleção da Amostragem ..........................................................

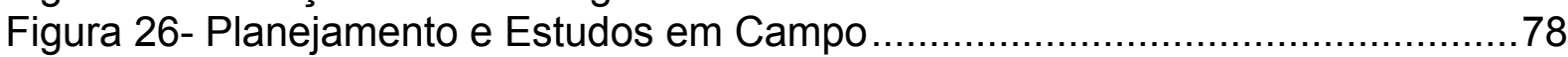

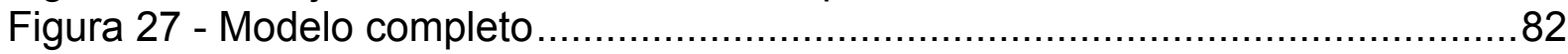

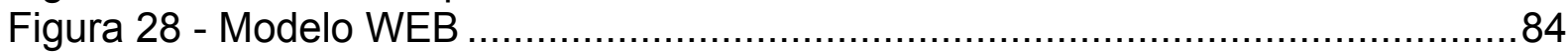

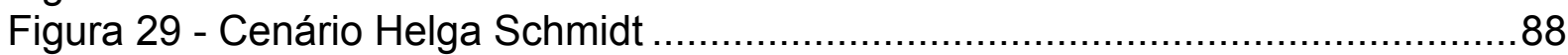

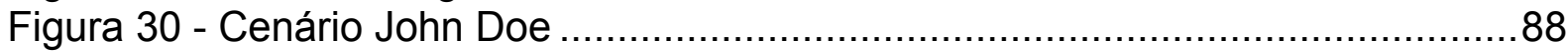

Figura 31 llustração de uma das tarefas do cenário John - original ........................89

Figura 32-llustração de uma das tarefas do cenário John - adaptado para o contexto

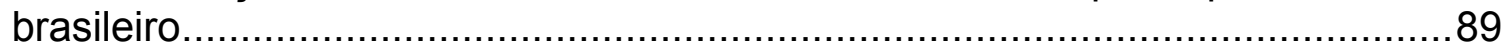

Figura 33Cenário Helga Schmidt adaptado para o contexto brasileiro ……….........90

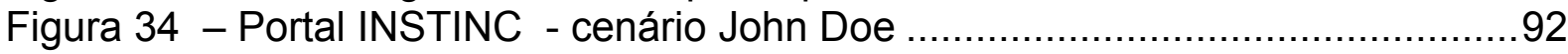

Figura 35 - Cenário do questionário Web....................................................117

Figura 36 - Versão original do Questionário Web............................................148

Figura 37 Acesso à programação de Noticias guia de TV ..................................148

Figura 38- Questão com múltiplas respostas possíveis ......................................149

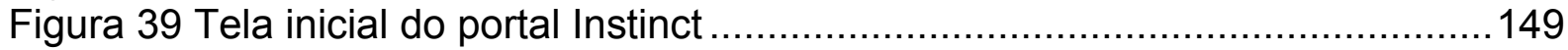

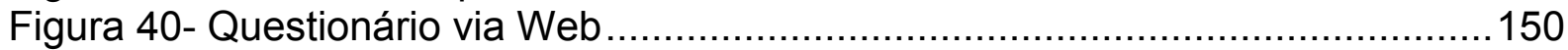




\section{LISTA DE TABELAS}

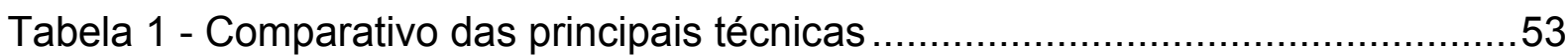

Tabela 2 - Roteiro para Levantar a Voz do Cliente..............................................61

Tabela 3 - Relação e Processo numa matriz...................................................62

Tabela 4 - Descrição dos entrevistados e critério de escolha ...............................91

Tabela 5 - Estrutura do questionário aplicado no cenário John Doe(original) ........93

Tabela 6- Parte das questões relacionadas ao cenário Helga Schidt .....................94

Tabela 7- Resultados do Pós questionário ................................................106

Tabela 8 - Comparação dos resultados brasileiro com o europeu .......................110 


\section{SUMARIO}

INTRODUÇÃO

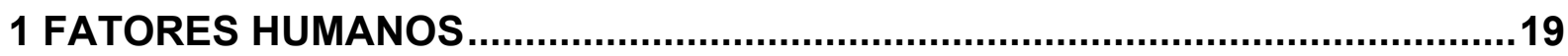

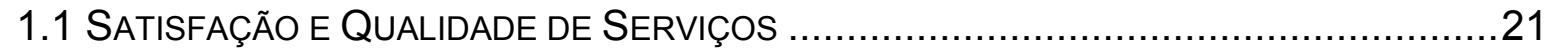

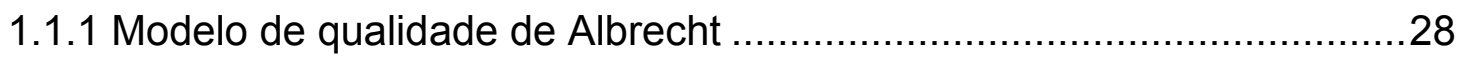

1.1.2 Modelo de Gronroos da qualidade do serviço percebida pelo usuário ..29

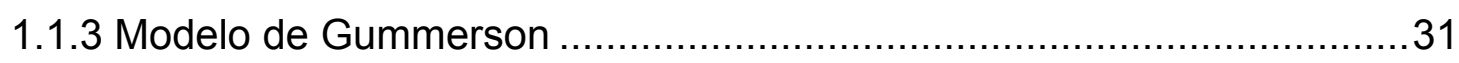

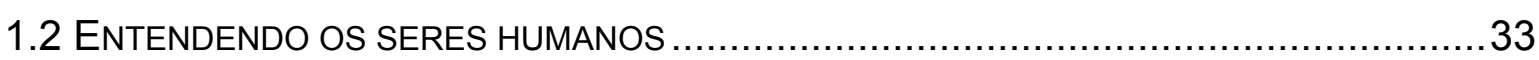

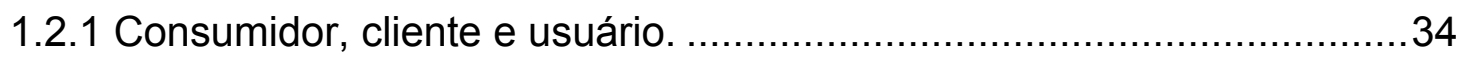

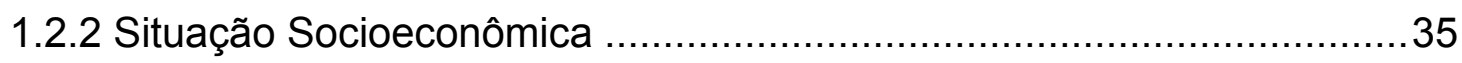

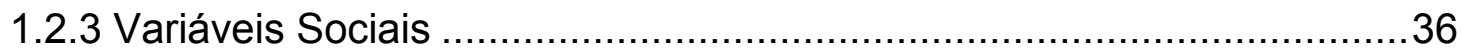

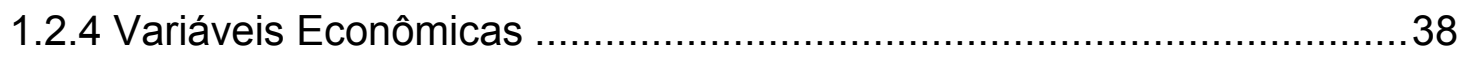

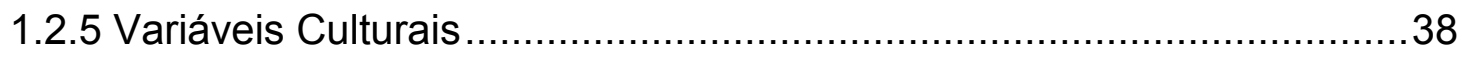

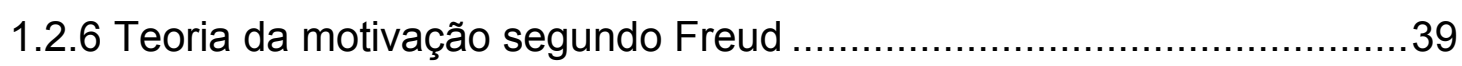

1.2.7 Teoria da motivação segundo Maslow ...............................................40

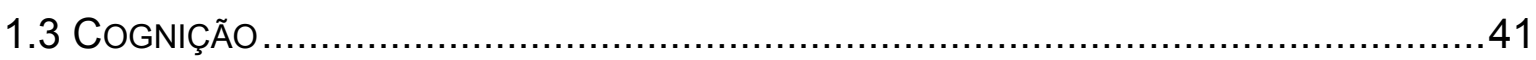

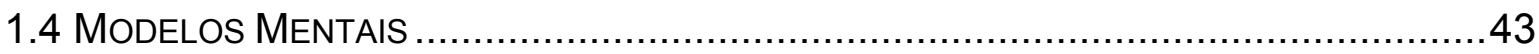

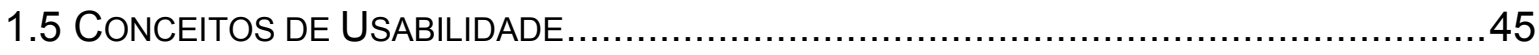

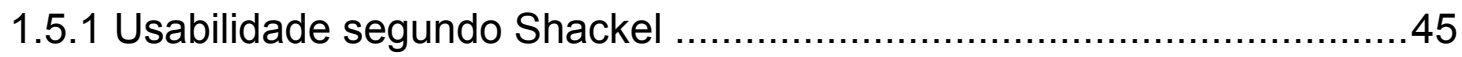

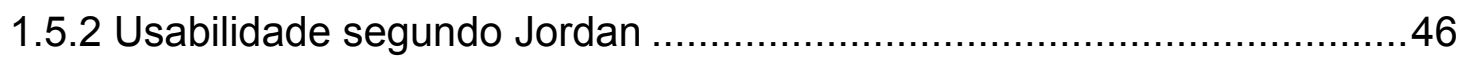

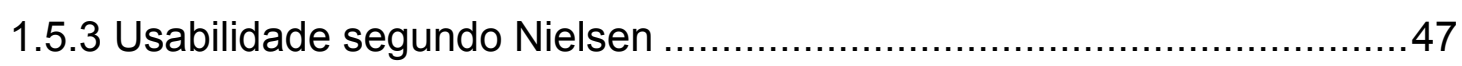

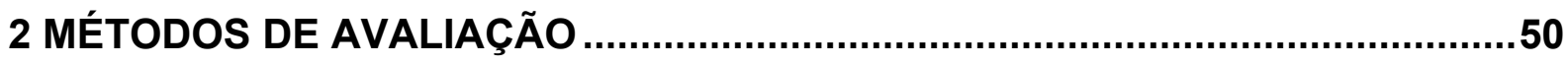

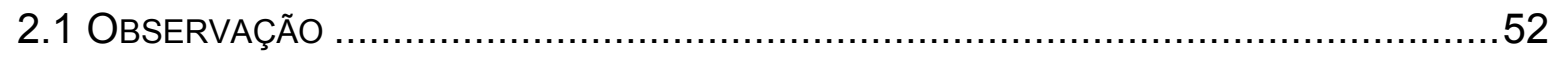

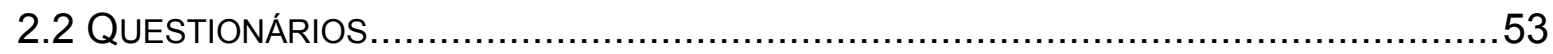

2.2.1 Questionnaire for User Interaction Satisfaction (Quis) ........................54

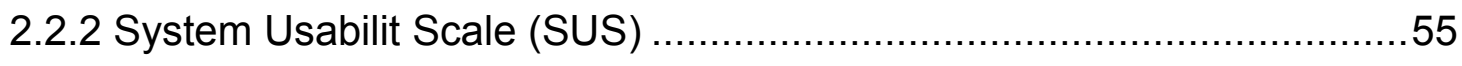

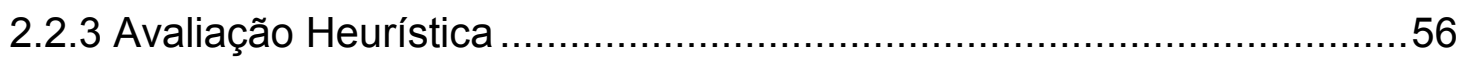

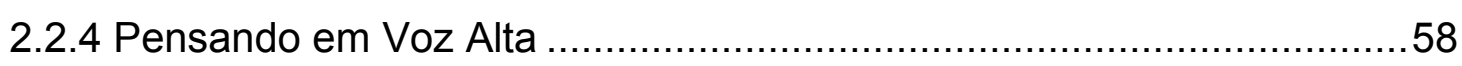

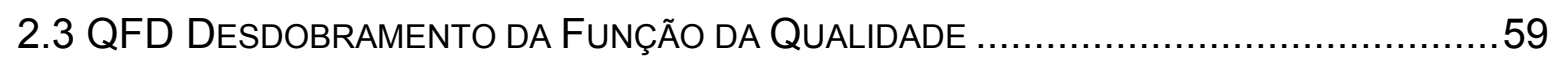

3 AMBIENTES CONVERGENTES HETEROGÊNEOS.........................................69

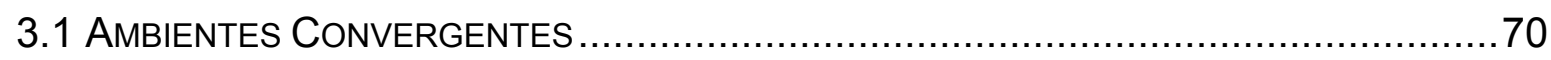

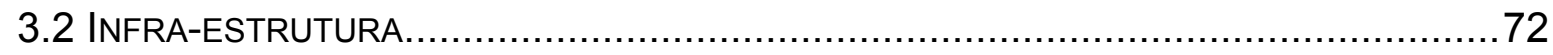

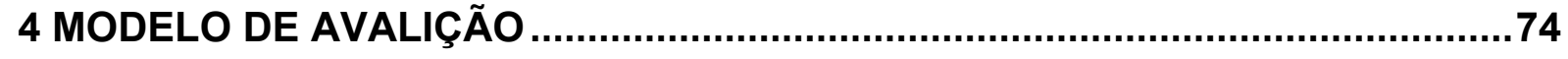




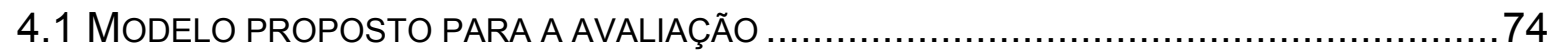

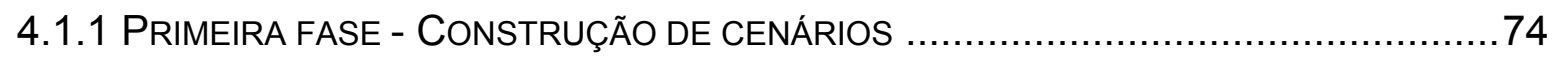

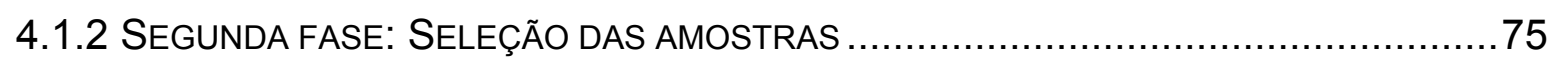

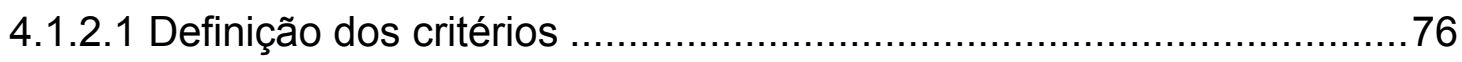

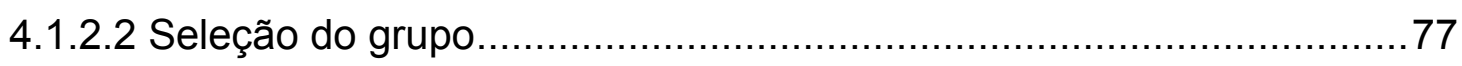

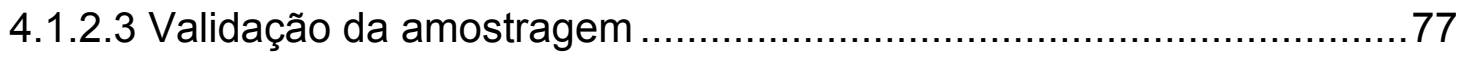

4.1.3 Terceira fase: Planejamento das atividades em campo e Entrevistas ...78

4.1.3.1 Desenvolvimento dos Questionários ...........................................78

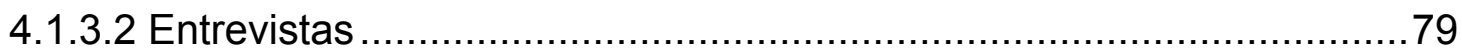

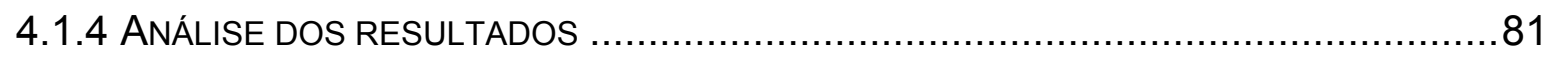

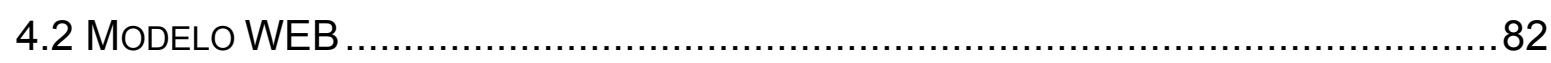

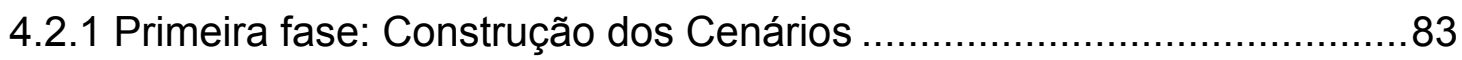

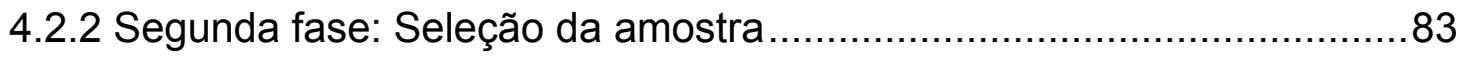

4.2.3 Terceira fase: Planejamento das atividades em campo e Entrevistas...84

5 APLICAÇÃO DO MODELO (ESTUDO DE CASO) .............................................86

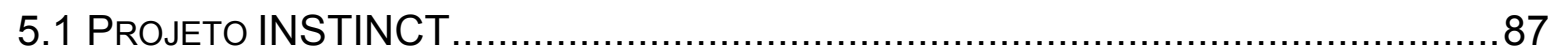

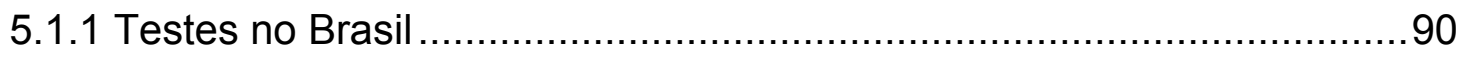

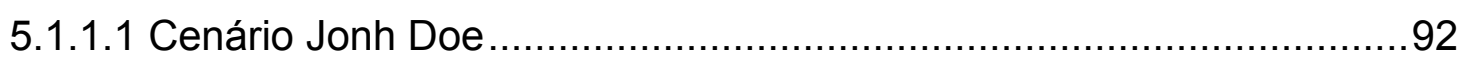

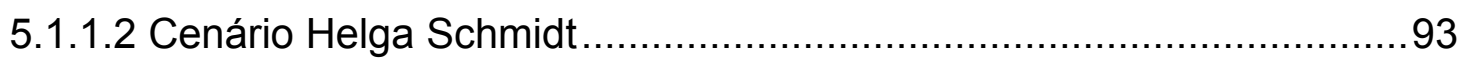

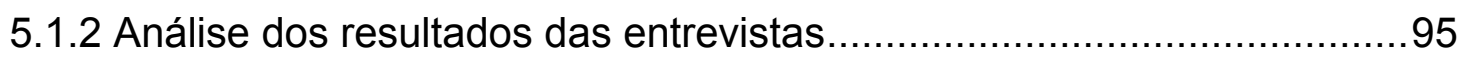

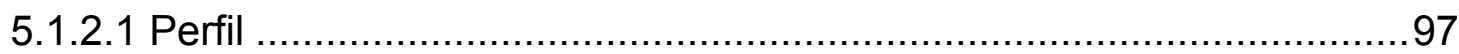

5.1.2.2 Possibilidade de recebimento de informações através de alertas ......98

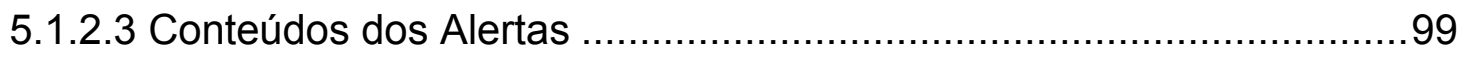

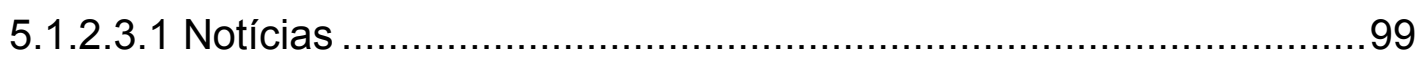

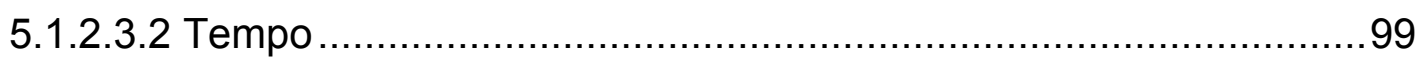

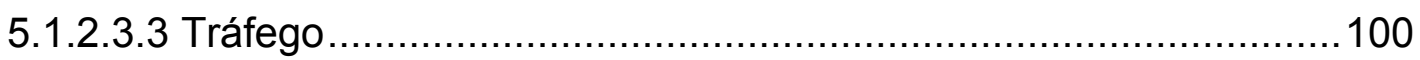

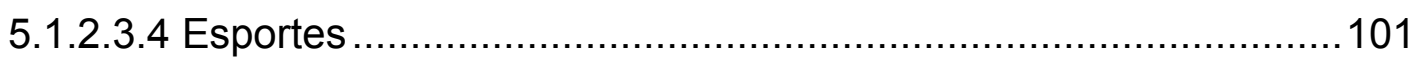

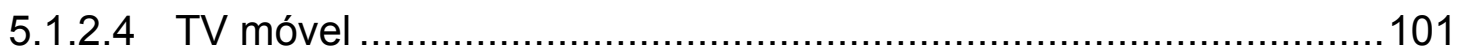

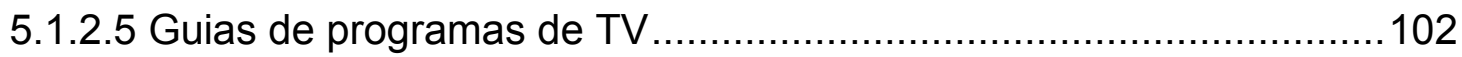

5.1.2.6 Interativos: quizzes, pop charts , votting ……............................. 102

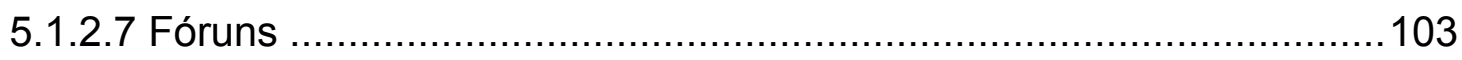

5.1.2.8 Comunicação pessoal on-line com troca de mensagens................... 103

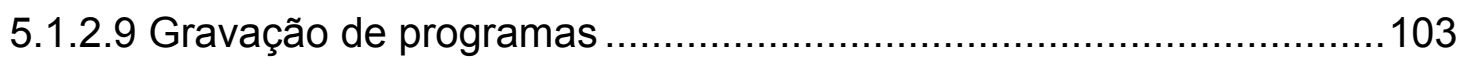

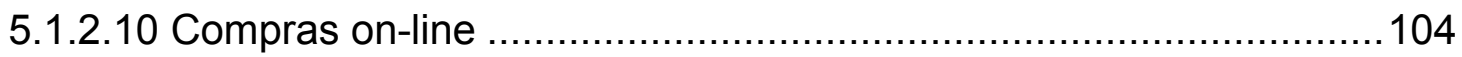


5.1.2.11 Assinatura de jornais/revistas 104

5.1.2.12 Guia de eventos e locais de interesse .......................................104

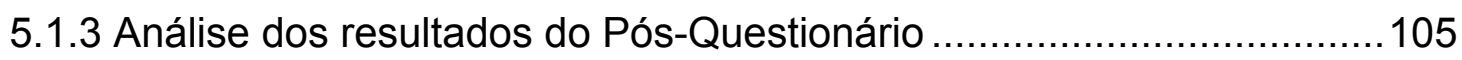

5.1.4 Análise dos dados obtidos a partir da amostragem brasileira .............107

5.1.5 Comparação com os resultados europeus ........................................109

5.1.6 Avaliação dos Resultados do trabalho.............................................111

5.1.7 Avaliação de produtos e serviços através da Web ….........................113

5.1.7.1 Motivação para a ampliação da amostragem ..................................114

5.1.7.2 Avaliação pelo questionário Web...............................................115

5.1.7.2.1 Cenário WEB: Portal INSTINCT ...........................................116

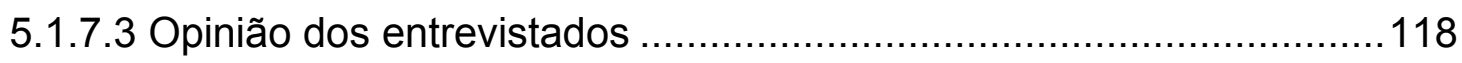

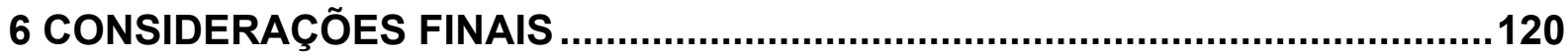

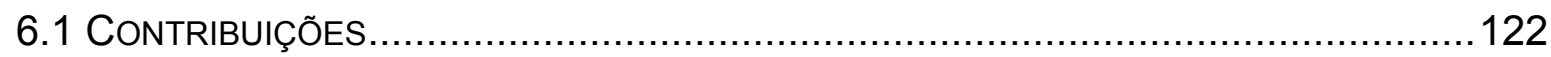

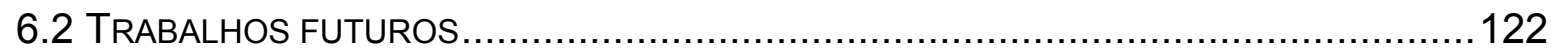

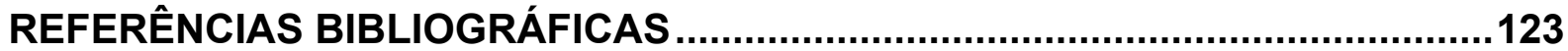

ANEXO A - PRES-TEST QUESTIONNAIRE ...................................................135

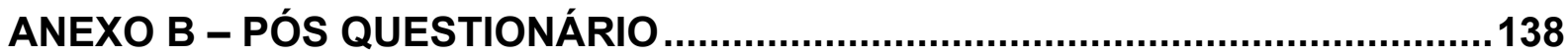

ANEXO C - GENERAL CROSS-SCENARIO QUESTIONS................................140

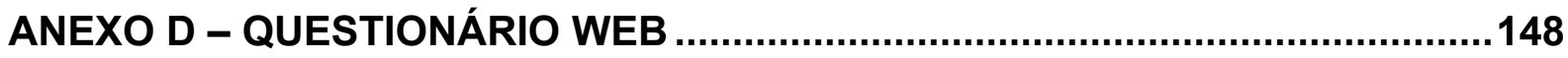




\section{INTRODUÇÃO}

A evolução tecnológica ocorrida desde o surgimento dos sistemas computacionais até os dias atuais vem provocando alterações significativas no relacionamento entre as pessoas e as máquinas. Shneiderman afirma que a tecnologia está se tornando algo intrínseco à sociedade[Shneiderman 1998].

Para diversos observadores e teóricos, entre eles Rosnay e Lojkine, hoje se presencia a chamada revolução informacional. Castells chama de Era da Informação e do Conhecimento. [Rosnay ,1998] , [Lojkine 1999], [Castells,1999].

A competitividade acirrada no mercado torna cada vez mais difícil o desenvolvimento de novos produtos, incluindo nessa definição também os serviços. Não há mais a possibilidade da experimentação ou de erro. O lançamento de um novo produto pode levar uma empresa à glória ou ao fracasso comercial rapidamente. Os custos envolvidos e a facilidade da informação levam o mercado a ser mais rigoroso.

Todo novo produto precisa encontrar no mercado seu nicho. Isso garantirá a sobrevivência da empresa. A aceitação do novo produto precisa ser avaliada por todas as formas possíveis antes do enfrentamento comercial. É ainda mais difícil consertar algo que não deu certo do que criar algo que dê certo. Acertar passa a ser a única meta de um produto novo.

Acertar no lançamento de um novo produto não é trivial, pois quem julga é o consumidor. Sua escala de valores é que irá motivá-lo, ou não, a consumir. Os valores e impressões são armazenados baseados em experiências anteriores, emoções, costumes e necessidades. Isso varia nas diferentes camadas sociais, geograficamente e no tempo. São muitas variáveis, algumas não mensuráveis. Não há uma regra geral que permita vislumbrar a aceitação de um produto no mercado.

Nielsen, define a aceitabilidade de um sistema como uma combinação adequada da aceitabilidade social, que é a aceitação pelas organizações e pelas suas características sociais, e a aceitabilidade prática que depende da adequação de suas características técnicas [Nielsen1993].

Pode-se considerar que esses fatores passam a integrar a definição de qualidade de um produto. Segundo Hernon e Altman , os modelos mais recentes de qualidade estão focados em descobrir quais são as expectativas dos clientes, pois quanto mais se aproximam dessas expectativas, maior qualidade esses serviços contêm [Hernon 
e Altman 1998].Qualidade é a diferença entre o que o consumidor espera e o que ele recebe. Incorporar qualidade é o primeiro passo no atual ambiente competitivo.

O problema do lançamento de um novo produto passa a ser a avaliação pelo ponto de vista de um consumidor previamente definido. Novas questões surgem:

- Como se pode conhecer a escala de valores do usuário?

- Quais as características do produto um usuário estará disposto a consumir?

- Que preço estará disposto a pagar?

- Como avaliar a satisfação com os serviços prestados?

- Com que facilidade o usuário interage com os produtos que lhe são apresentados?

Este trabalho propõe um modelo de avaliação da aceitabilidade de produtos e serviços e um método para sua utilização. Para tal, considera um novo fenômeno tecnológico que ocupa o centro das atenções: a convergência tecnológica. Os meios de comunicação estão em reformulação devido à entrada dos computadores, à sua popularidade, ao seu baixo custo relativo e ao apelo de consumo gerado por novos serviços e produtos.

De acordo com Sabatinni, a convergência interativa é uma nova tecnologia que integra o acesso à Internet e a recepção de canais de vídeo. Internet, TV e telefone em um mesmo aparelho [Sabatinni, 2000].

No cerne deste advento tecnológico, surgiram novos questionamentos, como, por exemplo, como será o comportamento das pessoas no uso da televisão interativa, quando já estão habituadas à passividade ou a pseudo-interação da televisão atual. Como deve proceder a sociedade ante as implicações políticas, culturais e sociais dos novos meios e como a comunicação pode adequar sua produção para a convergência tecnológica tendo em vista que uma mesma mensagem deve satisfazer diferentes características dos meios convergentes entre os quais alguns são passivos, outros reativos e outros interativos.

Para avaliar o comportamento do consumidor diante dessas indagações, este trabalho buscou respostas suportadas na psicologia, na área técnica de projeto de sistemas computacionais chamada Interação Homem-Computador, em engenharia de sistemas, normas e modelos de projetos e em ferramentas de simulação.

Este trabalho apresenta um modelo para avaliação de serviços convergentes sobre redes heterogêneas utilizando cenários e entrevistas com potenciais consumidores 
usuários dos serviços propostos. O modelo foi exercitado em casos reais e teve seus resultados confrontados com estudos equivalentes realizados por equipes diversas na Europa.

Os resultados atenderam às expectativas de um projeto internacional, entretanto, ficou evidente que diferenças regionais e distâncias de mercados consumidores podem elevar demasiadamente o custo dessa avaliação. O modelo foi modificado para atender a esses novos problemas e foi desenvolvido um cenário voltado para a utilização através da Internet, eliminando muitos custos de viagens apenas aprimorando os cenários e modelos de navegação. Os resultados obtidos com a utilização da web confirmaram os resultados obtidos pelo modelo presencial.

\section{Objetivos:}

Os principais objetivos desse trabalho são:

- Definir um modelo de trabalho para avaliar a aceitabilidade de produtos, incluindo serviços, softwares, equipamentos e modelos de negócio, assim como o método de aplicação desse modelo para minimizar o tempo de desenvolvimento e facilitar o acerto do produto final;

- Definir o uso de técnicas e ferramentas de áreas diversas, incluindo psicologia, técnicas de projeto de sistemas computacionais na Interação Homem-Computador, engenharia de sistemas, normas e modelos de projetos da engenharia da qualidade, além de ferramentas de simulações.

- Avaliar a aceitabilidade dos produtos, através da utilização do modelo desenvolvido, por diferentes populações e determinar a influência dessa diversidade geográfica, por exemplo, fazendo uso também da Web;

- Verificar a influência da avaliação dessa aceitabilidade em projetos de produtos convergentes em ambientes heterogêneos de acordo com o modelo proposto em estudos de casos, descrevendo seus resultados.

\section{Justificativa:}

A utilização de cenários para avaliação de serviços em ambientes convergentes promoveu resultados positivos para o desenvolvimento deste trabalho, pois de acordo com Carroll os cenários são narrativas, textuais ou pictóricas de uma situação de uso de uma aplicação envolvendo usuários, equipamentos, processos e dados reais ou potenciais. Por serem instâncias de caso de uso, os cenários são 
ricos em detalhes contextuais, conforme afirma Jacobson. Além disso, o baixo custo dos cenários facilita muito o aumento de interações entre os potenciais usuários e os projetistas de sistemas [Jacobson et al 1992].

O modelo desenvolvido permite avaliação de aceitabilidade de produtos como meio eficaz de trabalho direto com o usuário. $O$ modelo permite ainda atingir uma amostragem significativa de usuários com diversidade cultural expressiva de maneira concisa, com baixo custo e eficaz através da utilização da Web.

É preciso atender às necessidades dos usuários de acordo com o seu perfil cultural. Na disputa por um usuário fiel, é preciso conhecê-lo de maneira diferenciada.

\section{Metodologia:}

Este trabalho apresenta uma investigação de forma científica seguindo as seguintes etapas [Marconi; Lakatos, 2004]:

- $\quad$ Descobrimento do problema;

- $\quad$ Colocação precisa do problema;

- $\quad$ Procura de conhecimentos ou instrumentos relevantes ao problema;

- Tentativa de solução do problema com o auxílio dos meios identificados;

- Invenção de novas idéias;

- $\quad$ Produção de novos dados empíricos;

- $\quad$ Obtenção de uma solução;

- $\quad$ Investigação das conseqüências da solução obtida;

- $\quad$ Prova (comprovação da solução);

- Correção das hipóteses, teorias, procedimento ou dados empregados na obtenção da solução correta.

- A principal questão que esse trabalho responde é sobre a possibilidade de se prever a aceitabilidade de um novo produto por consumidores previamente definidos antes que o produto exista. Todas as alterações de rumo que um projeto defina em suas fases iniciais são mais facilmente resolvidas durante o projeto. Um produto mal definido não terá um projeto fácil e seu sucesso no mercado dependerá apenas de sorte. 


\section{Estrutura do trabalho:}

O capítulo 1 da tese aborda conceitos de Fatores Humanos necessários para 0 desenvolvimento deste trabalho, ou seja: qualidade de serviços, cognição, modelos mentais, satisfação do cliente.

O capítulo 2 apresenta uma descrição dos métodos de avaliação da usabilidade em fatores humanos, tais como as técnicas de observação, questionários, entre outros.

O capítulo 3 aborda os ambientes convergentes, o propósito desse capítulo é explanar a estrutura destes ambientes, pois este trabalho avaliou serviços que serão oferecidos aos usuários brasileiros nesses ambientes.

O capítulo 4 apresenta a metodologia que gerou o desenvolvimento modelo de avaliação de serviços convergentes em ambientes heterogêneos.

O capítulo 5 descreve dois estudos de caso que foram o alicerce para chegar ao modelo de avaliação.

Finalmente, o capítulo 6 apresenta os comentários finais, ressaltando as contribuições deste trabalho e sugerindo futuras pesquisas que possam complementar a abordagem apresentada aqui. 


\section{FATORES HUMANOS}

Este capítulo detalha os conceitos dos Fatores Humanos em projetos de sistemas computacionais e ressalta os itens que deram apoio a este trabalho. O nome "Fatores Humanos" é mais comumente utilizado na América do Norte enquanto o termo Ergonomia é mais utilizado na Europa. Nesse trabalho serão considerados sinônimos.

Segundo Karwowski trata-se de uma disciplina científica relacionada ao entendimento das interações entre os seres humanos e outros elementos ou sistemas, e à aplicação de teorias, princípios, dados e métodos a projetos a fim de otimizar o bem estar humano e o desempenho global do sistema. Além disso, os Fatores Humanos integram o conhecimento proveniente das ciências humanas para adaptar tarefas, sistemas, produtos e ambientes às habilidades e limitações físicas e mentais das pessoas [Karwowski 1996].

A referência Cañas e Waerns, por exemplo, define uma das especializações dos fatores humanos, a área cognitiva. Esta área refere-se aos processos mentais, tais como percepção, memória, raciocínio e resposta motora conforme afetem as interações entre seres humanos e outros elementos de um sistema. Os tópicos relevantes incluem o estudo da carga mental de trabalho, tomada de decisão, desempenho especializado, interação homem computador, stress e treinamento conforme esses se relacionem a projetos envolvendo seres humanos e sistemas [Cañas e Waerns,2001]. De acordo com Marmahas e Kontogiannis a área cognitiva não tem por fim teorizar sobre a cognição humana, seu papel está em compatibilizar as soluções tecnológicas às características e necessidades de seus usuários [Marmahas e Kontogiannis, 2001]. Para tanto, ela busca entender a cognição de forma situada e finalística, ou seja, dentro de um contexto específico de ação e voltada para alcançar um objetivo, conforme Sarmet, ou, ainda, como afirma Hollnagel, a área cognitiva dos Fatores Humanos não é tentar entender a natureza da cognição humana, mas descrever como a cognição humana afeta o processo laborativo e como por ele é afetada [Sarmet,2003;Hollnagel ,1997].

Dentro deste contexto, os Fatores Humanos contribuiram neste trabalho por situarse, como descreve Moraes, como mediadores entre as ciências que estudam os 
diversos aspectos do ser humano e as diversas tecnologias projetuais, para as quais fornece recomendações que viabilizam projetos e ambientes humanos [Moraes,1993]. A figura 01 apresenta, esquematicamente, as fronteiras da Ergonomia, da Ciência e da Tecnologia. Moraes, ainda, afirma que a Ergonomia apresenta dois enfoques: o americano e o europeu. De acordo com o pesquisador, a concepção americana preocupa-se, principalmente, com os aspectos físicos da interface homem-máquina, ou seja, os aspectos anatômicos, antropométricos, fisiológicos e sensoriais, objetivando dimensionar a estação de trabalho, facilitando a discriminação de informações dos mostradores e a manipulação dos controles. A linha européia, entretanto, privilegia as atividades do operador, priorizando o entendimento da tarefa, os mecanismos de seleção de informações, de resolução de problemas e de tomada de decisão [Moraes,1993].

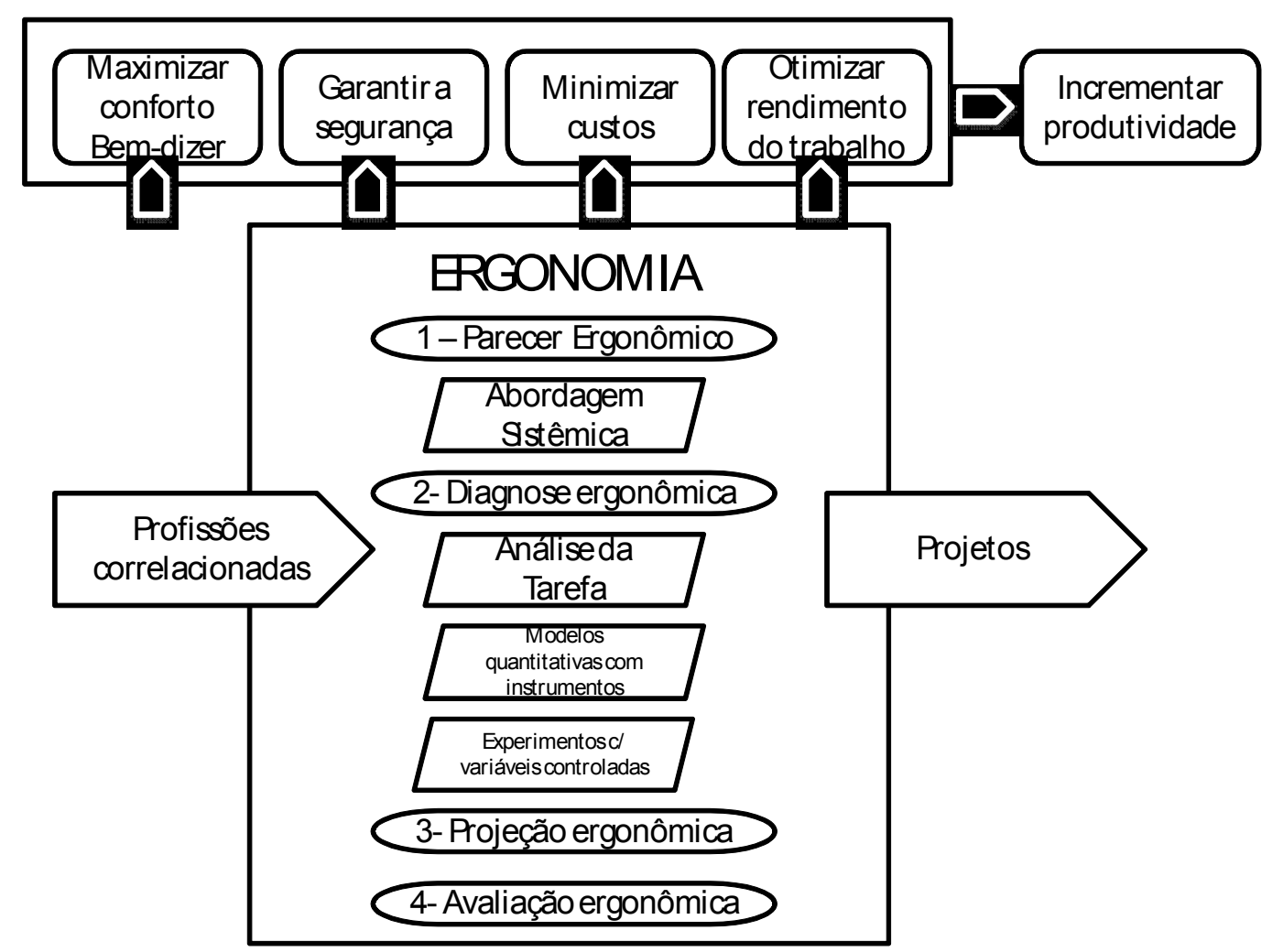

Figura 1 - Fronteiras da Ergonomia, Ciência e Tecnologia: Projetos Ergonômicos Fonte: Adaptado de MORAES, 1993.

Dando continuidade aos fatores que interferem na decisão humana, o próximo capítulo abordará os fatores responsáveis pela qualidade e como conseqüência a satisfação do usuário. A importância deste tema vem ao encontro do objetivo deste trabalho: averiguar o que faz o indivíduo satisfeito seja na posição de cliente, usuário 
ou consumidor. Para isto, a qualidade e a satisfação, uma vez que uma depende da outra, é fator chave de sucesso.

\subsection{Satisfação e Qualidade de Serviços}

Este capítulo fornece uma breve visão do cenário atual, onde a satisfação e qualidade de Serviços estão intrinsecamente ligadas.

Hernon e Altman afirmam que os modelos atuais de qualidade estão focados em descobrir quais são as expectativas dos clientes, pois quanto mais se aproximam dessas expectativas, maior qualidade esses serviços contêm. Incorporar qualidade é o primeiro passo para reter o usuário no atual ambiente competitivo, e a qualidade é a característica necessária para a competitividade das empresas e instituições prestadoras de serviços no mundo atual [Hernon e Altman,1998].

De forma similar, em Lovelock e Wright a qualidade em serviços pode ser conceituada como o grau em que um serviço atende ou supera as expectativas do cliente. Logo, se as expectativas são atendidas ou superadas, os clientes acreditam que receberam um serviço de qualidade e se tornam mais propensos a repetir a compra ou a serem fiéis [Lovelock e Wright 2001].

Para Zeithaml, Parasuraman e Berry a qualidade em serviços depende da percepção do cliente, além disso, sugerem cinco dimensões que os clientes utilizam para julgar a qualidade, baseadas na comparação que fazem entre suas expectativas e percepções. A figura 2 apresenta a relação entre as expectativas do serviço moldadas pelo cliente, como este pode percebê-lo e as dimensões da qualidade nos serviços [Zeithaml, Parasuraman e Berry,1985]. 


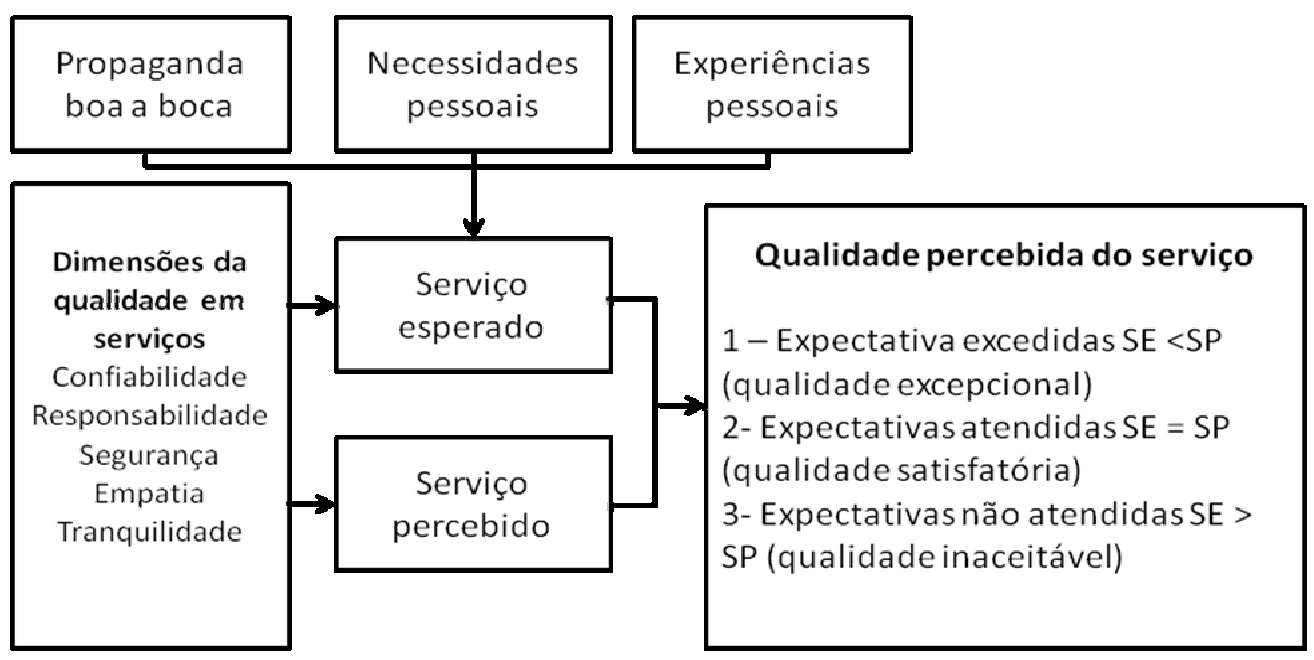

Figura 2 - Qualidade percebida do serviço

Fonte: Zeithaml, Parasuraman, Berry, 1985.

Aplicando a teoria encontrada em Las Casas, serviço de qualidade é aquele em que o cliente fica satisfeito com os resultados obtidos, de acordo com suas expectativas. Segundo o autor, superar as expectativas dos clientes é a obtenção da excelência em serviços [Las Casas, 1995].

Assim sendo, quando o resultado da "equação" for igual ou maior que zero, a qualidade do serviço realizado é satisfatória [Las Casas, 1995].

Garvin define a qualidade fazendo uma taxonomia: [Garvin,2002]

- $\quad$ Transcendental: qualidade como sinônimo de excelência inata.;

- $\quad$ Centrada em manufatura: preocupa-se em fazer produtos livres de erros e que correspondem precisamente às especificações de projeto;

- $\quad$ Centrada no valor: define qualidade em termos de custo e benefício. Essa abordagem defende que a qualidade seja percebida em relação ao preço;

- Centrada no produto: vê a qualidade segundo um conjunto mensurável e preciso de características, que são requeridas para satisfazer o consumidor;

- $\quad$ Centrada no usuário: assegura que o produto ou serviço está adequado a seu propósito.

Segundo Locke, a satisfação é "um sentimento que resulta da percepção de que o trabalho realiza ou permite a realização de valores importantes relativos ao próprio trabalho" [1976, apud Wagner III; Hollenbeck, 1999, p.121]. Então, pode-se dizer que satisfação nos serviços é o sentimento positivo de percepção que a pessoa possui do próprio serviço. 
Para Kotler, "satisfação é o nível de sentimento de uma pessoa, resultante da comparação do desempenho (ou resultado) de um produto em relação às suas expectativas". Assim, o nível de satisfação é uma função da diferença entre o desempenho percebido e as expectativas, o que equivale a dizer que a satisfação ocorre quando o valor entregue à pessoa se iguala ao valor esperado. Uma pessoa pode, então, experimentar três níveis de satisfação [Kotler ,1998]:

- Insatisfeito, se o valor entregue ficar longe das expectativas;

- $\quad$ Satisfeito, se o valor entregue atender suas expectativas;

- $\quad$ Altamente satisfeito, se o valor entregue exceder suas expectativas.

O valor total esperado pela pessoa é "o conjunto de benefícios previstos por determinado produto ou serviço". Assim, Kotler avalia o produto em termos de confiabilidade, durabilidade e desempenho. Além disso, percebe as diferenças nos serviços oferecidos - entrega, treinamento e manutenção; também percebe se os funcionários são atenciosos e se a imagem da empresa é boa. Depois disso, soma todos os valores das cinco fontes: produto, serviços, funcionamento, imagem e custo. [Kotler ,1998]

"Identificar critérios segundo os quais as pessoas avaliam os serviços é uma forma de melhor compreender as expectativas delas" e, Gianesi e Corrêa, por exemplo, afirmam que as pessoas avaliam os serviços de acordo com os seguintes critérios:

Tangíveis: Qualidade e/ou aparência de qualquer evidência física: bens facilitadores, equipamentos, instalações, pessoal, outros consumidores;

- Consistência: Conformidade com experiência anterior; ausência de variabilidade no resultado ou processo;

- Competência: Habilidade e conhecimento para executar o serviço. Relacionase com as necessidades "técnicas" dos consumidores;

- Velocidade de atendimento Prontidão da empresa e seus funcionários em prestar o serviço. Relaciona-se com o tempo de espera real ou percebido;

- $\quad$ Atendimento/atmosfera Atenção personalizada ao cliente, boa comunicação cortesia, ambiente;

- $\quad$ Flexibilidade: Ser capaz de mudar e adaptar a operação, perante mudanças;

- $\quad$ Credibilidade/segurança: Baixa percepção de risco; habilidade de transmitir confiança;

- $\quad$ Acesso: Facilidade de contato e acesso; localização conveniente; horas de Operação; 
- $\quad$ Custo: Fornecer serviço de baixo custo .

Para a realização de qualquer pesquisa sobre a avaliação da qualidade de serviços pelos clientes é necessário analisar alguns atributos [Las Casas,1999]:

- Confiabilidade: É importante para prestar serviços de qualidade, gerada pela habilidade de fornecer o que foi prometido de forma precisa;

- Segurança: As pessoas querem habilidade de transmitir segurança e confiança caracterizada pelo conhecimento e cortesia dos funcionários dos prestadores de serviços;

- Aspectos tangíveis: Os aspectos físicos que circundam a atividade de prestação de serviços também têm sua importância como as instalações, equipamentos e aparência dos funcionários;

- Empatia: Grau de cuidado e atenção pessoal dispensado pelos clientes. Também são importantes aspectos como a capacidade de se colocar no lugar dos outros;

- $\quad$ Receptividade: É a disposição de ajudar os clientes e fornecer serviços com presteza.

Segundo Las Casas "Esses atributos podem ser vistos de certa forma como requisitos essenciais para que os momentos da verdade ocorram de acordo com determinado nível de expectativas dos clientes" [Las Casas ,1999].

Um nível de qualidade de serviço, comparado aos seus concorrentes, que é suficientemente elevado, do ponto de vista dos seus clientes, para lhe permitir cobrar um preço mais alto pelo serviço oferecido, conquistar uma participação de mercado acima do que seria considerado natural, e/ou obter uma margem de lucro maior do que a de seus concorrentes [Albrecht,1992].

Las Casas afirma que o produto final de um serviço é sempre um sentimento. As pessoas ficam satisfeitas ou não conforme suas expectativas. Portanto, a qualidade do serviço é variável de acordo com o tipo de pessoa. Uma má experiência em relação a um serviço vivenciada pela pessoa ou relatada a ela terá um efeito extremamente negativo na formação das suas expectativas em relação a uma determinada empresa ou até mesmo a todas de um mesmo segmento. A figura 3 demonstra como são formadas as expectativas das pessoas [Las Casas ,1995]. 


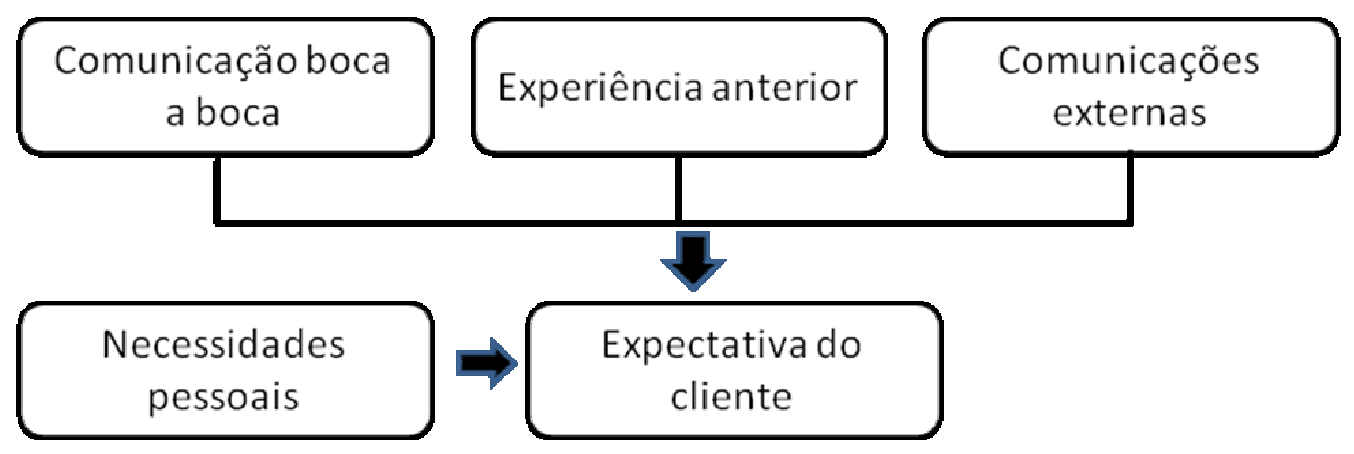

Figura 3 - Fatores de influência na formação da expectativa do cliente

A qualidade de serviços é definida como a diferença entre as expectativas que as pessoas têm em relação ao desempenho do serviço, tanto pelo próprio serviço, como pelas percepções [Parasuraman et al. ,1985, apud Paiva, 2001].

Conforme os autores, os atributos têm as seguintes dimensões:

- Confiabilidade: Fazer o serviço certo da primeira vez, honrando as promessas;

- Responsabilidade: Diz respeito à prontidão com que os serviços são prestados pelos funcionários;

- $\quad$ Competência: Ter as habilidades necessárias e o conhecimento para realizar o serviço;

- Acesso: Facilidade de contato, tempo esperado pelo serviço, horários de operação, locais convenientes;

- $\quad$ Cortesia: Aspectos esperados daqueles que contatam o cliente envolvendo educação, amizade, consideração, entre outros;

- Comunicação: Manter o cliente informado utilizando uma linguagem que ele entenda;

- $\quad$ Credibilidade: Confiança e honestidade;

- Segurança: Preocupação com o perigo, risco e duvida que o serviço pode trazer;

- $\quad$ Entendimento do cliente: Esforço para entender as necessidades dos clientes;

- Aspectos tangíveis: Evidências físicas do serviço, instalações, aparência pessoal, equipamentos utilizados, entre outros. 
De acordo com Oliver a satisfação da pessoa é a resposta de realização, que julga as características de um serviço ou produto, proporcionando prazer de realização ao consumo [Oliver apud Zuniga; Urdan, 2000].

Segundo Kotler, a maioria das empresas dedica mais atenção à participação no mercado do que à satisfação do cliente, não tendo a percepção de que, ao cair o nível da satisfação, inicia o desgaste da participação no mercado [Kotler,2003].

Para Las Casas, conhecer as características externas, gerais e as necessidades individuais dos clientes facilita a superação das expectativas. De um lado, percebese que a formação de imagem depende de atividades freqüentes e que transmitem o nível de qualidade desejado. De outro lado, que o significado da qualidade na mente das pessoas é uma idéia individualizada [Las Casas,1999].

Para Poter, é necessário estar atento às mudanças de necessidades. Nesse sentido, a mudança tem a ver com evolução das necessidades das pessoas e,com a evolução de tecnologias para satisfazer as necessidades dos mesmos" [Porter,2000].

É justamente nesse aspecto que se define o conceito de qualidade como "adequação ao uso". Isso reafirma a superioridade da abordagem centrada no usuário, pois pressupõe que, para se oferecer qualidade, é necessário, antes de qualquer ação, compreender qual é o desejo das pessoas além de conhecer qual é a idéia que elas tem acerca do que é qualidade para aquele produto. Portanto, um produto, para ter qualidade, deve possuir as características que atendem às necessidades das pessoas e não ter deficiências. A noção de qualidade é muito ampla para que se possa utilizá-la como meta na gestão das operações de serviço. Por isso, ao se avaliar a qualidade de serviços, deve-se compreender que cada atividade será uma sedimentação para a formação de imagem futura e quanto mais essas atividades se aproximarem do nível de qualidade desejado, mais forte a qualidade estará associada ao produto. Tudo isso deve adicionado a um constante esforço em medir a satisfação. As definições baseadas nos serviços igualam qualidade à satisfação do indivíduo, conforme a fórmula, segundo Lovelock e Wright:

Satisfação =serviço percebido/serviço esperado 
A qualidade do serviço é o grau em que um serviço atende ou supera as expectativas do indivíduo [Lovelock e Wright , 2003].

Os consumidores avaliam a qualidade de serviço julgando a partir de um padrão interno que existia antes da experiência do serviço. Esse padrão interno para julgar a qualidade é base para as expectativas do cliente [Lovelock; Wright, 2003].

Em Johnston e Clark a qualidade do serviço é usada com o mesmo significado de satisfação, isto é, o grau de ajustamento entre as expectativas do indivíduo e as percepções de um serviço. A forma de distingui-las é que a qualidade em serviço é mais freqüentemente usada com algo mais duradouro, enquanto a satisfação é específica da situação da experiência [Johnston e Clark,2002].

Os autores acima consideram que a expectativa das pessoas apresenta uma faixa de tolerância, conforme mostra a figura 04 , na qual as expectativas se localizam em algum ponto entre o ideal e o intolerável.

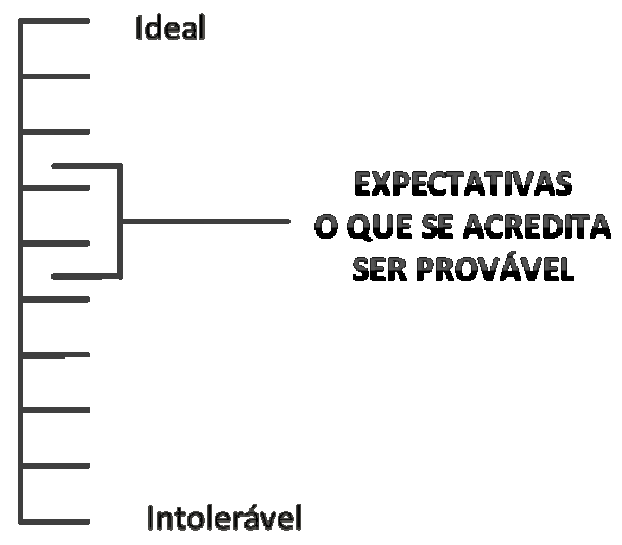

Figura 4 - Faixa de expectativa FONTE: Johnston; Clark, 2000.

Em Johnston e Clark se definem alguns desses pontos:

- Ideal: O melhor possível;

- Ideal factível: O que deve acontecer, dado o preço ou o padrão setorial;

- Desejável: O padrão que o cliente deseja receber;

- Obrigatório: O nível de desempenho que o cliente deve receber, dados os custos percebidos;

- Mínimo tolerável: Os padrões que os clientes não devem receber.

Esses autores ainda afirmam que, de acordo essa faixa, a área de tolerância é definida entre os padrões desejados e os mínimos aceitáveis. A importância dessa zona é que as pessoas podem aceitar variação dentro de uma faixa de desempenho e qualquer aumento ou diminuição de desempenho nessa área terá efeito marginal 
sobre as suas percepções [Johnston e Clark, 2002]. O desempenho terá qualquer efeito real sobre a qualidade percebida do serviço apenas quando estiver fora dessa faixa. Essa faixa ou zona de expectativa, como mostra a figura 5, indica uma área de tolerância, definida entre os padrões desejados e os mínimos aceitáveis. [Zeithaml; Berry; Parasuraman, 1985].

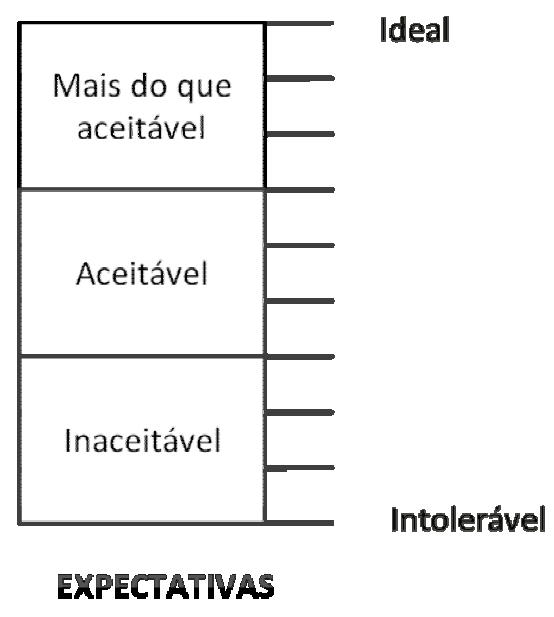

Figura 5 - Zona de tolerância ou aceitabilidade Fonte: Johnston; Clark, 2000.

A crescente preocupação com a qualidade fez com que modelos de qualidade de serviços fossem desenvolvidos, entretanto, não se tem encontrado material adequado sobre a avaliação dos serviços e/ou produtos.

Para o desenvolvimento do modelo de avaliação de novos serviços convergentes em ambientes heterogêneos proposto nesse trabalho, alguns modelos de qualidade em serviços e conceitos sobre usabilidade são descritos a seguir.

\subsubsection{Modelo de qualidade de Albrecht}

Albrecht havia idealizado o triângulo do serviço como uma forma prática de desenhar a operação dos serviços [Albrecht, 1998]. A meta de qualidade na prestação de serviço é alcançada toda vez que há: uma estratégia de serviço, profissionais de linha de frente para atender o usuário, principalmente, os sistemas voltados efetivamente para o eles como é demonstrado na figura 06. 


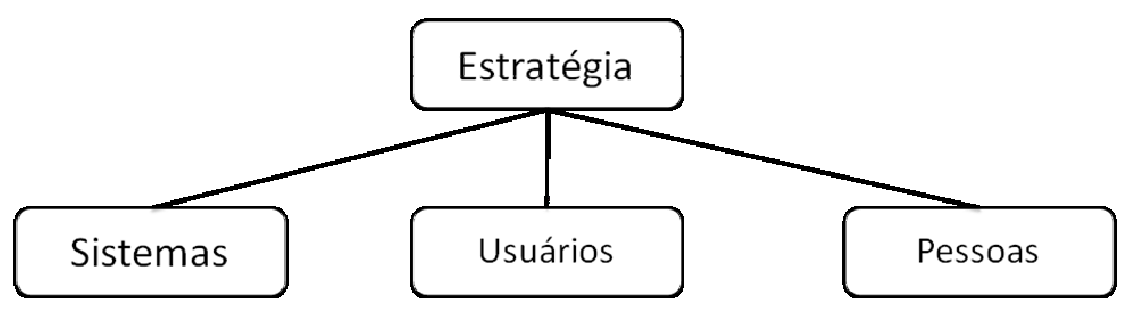

Figura 6 - 0 triângulo dos serviços

O centro do modelo de Albrecht é o usuário. Ele precisa ser definido tanto em termos de dados demográficos quanto em características psicológicas Os dados demográficos são aqueles que formam o perfil factual ou numérico dos vários segmentos de usuários, aos quais a organização pretende atingir com um produto ou serviço. Eles contêm informações sobre as principais características básicas dos usuários, tais como: idade, sexo, estado civil, dados familiares, ocupação, renda, formação, origem étnica e tipo de moradia [Albrecht,1992], enquanto as características psicológicas são os principais responsáveis pelos fatores fundamentais as fichas de avaliação dos usuários. Esses dados tratam-se dos acontecimentos significativos que demonstram se os consumidores estão satisfeitos ou não com o produto ou serviço. Além disso, eles ainda podem definir os motivos para influenciar os usuários nas relações com a organização de serviços.

Albrecht relata que as pessoas que trabalham em serviços devem saber resolver as reclamações e reagir segundo os vários tipos de usuários. $O$ autor classificou os usuários em: Submissos, Agressivos e Abastados, sendo que estes sempre encontram algo errado no produto ou serviço. Nunca estão satisfeitos [Albrecht,1992, 1995a, 1995b, 1998 ].

\subsubsection{Modelo de Gronroos da qualidade do serviço percebida pelo usuário}

Segundo Gronroos a qualidade de um serviço está em considerá-lo do ponto de vista dos consumidores, pois os consumidores escolhem prestadores de serviço comparando as percepções que têm do serviço recebido como o serviço esperado, o que é chamado de qualidade percebida. Quando se obtém bons resultados na 
qualidade percebida significa que foram atendidas as expectividades dos clientes. Nestes termos, o autor argumenta que a qualidade é o que os clientes percebem.

Para os usuários a qualidade tem duas dimensões: uma dimensão ou resultado técnico e uma dimensão funcional ou relacional a processo, conforme a figura 07 [Gross, 1985].

O usuário é influenciado pela forma como recebe o serviço e como vivencia o processo de produção e consumo simultâneos.

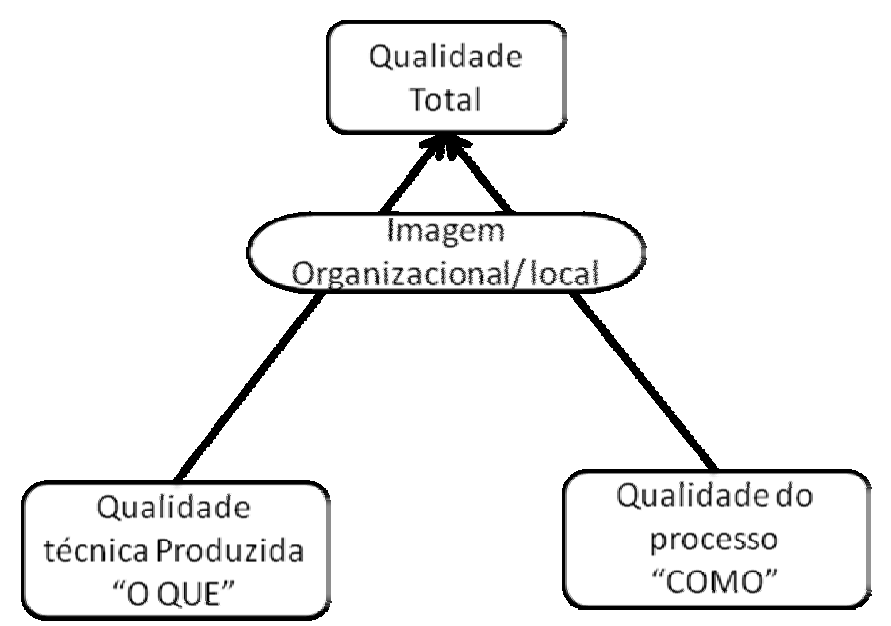

Figura 7 - Dimensões de qualidade de serviços segundo Gronroos

O autor afirma que boa qualidade é percebida quando a qualidade experimentada atende às expectativas do usuário, ou seja, à qualidade esperada. A figura 8 apresenta esse modelo [Gronroos,1988]. 


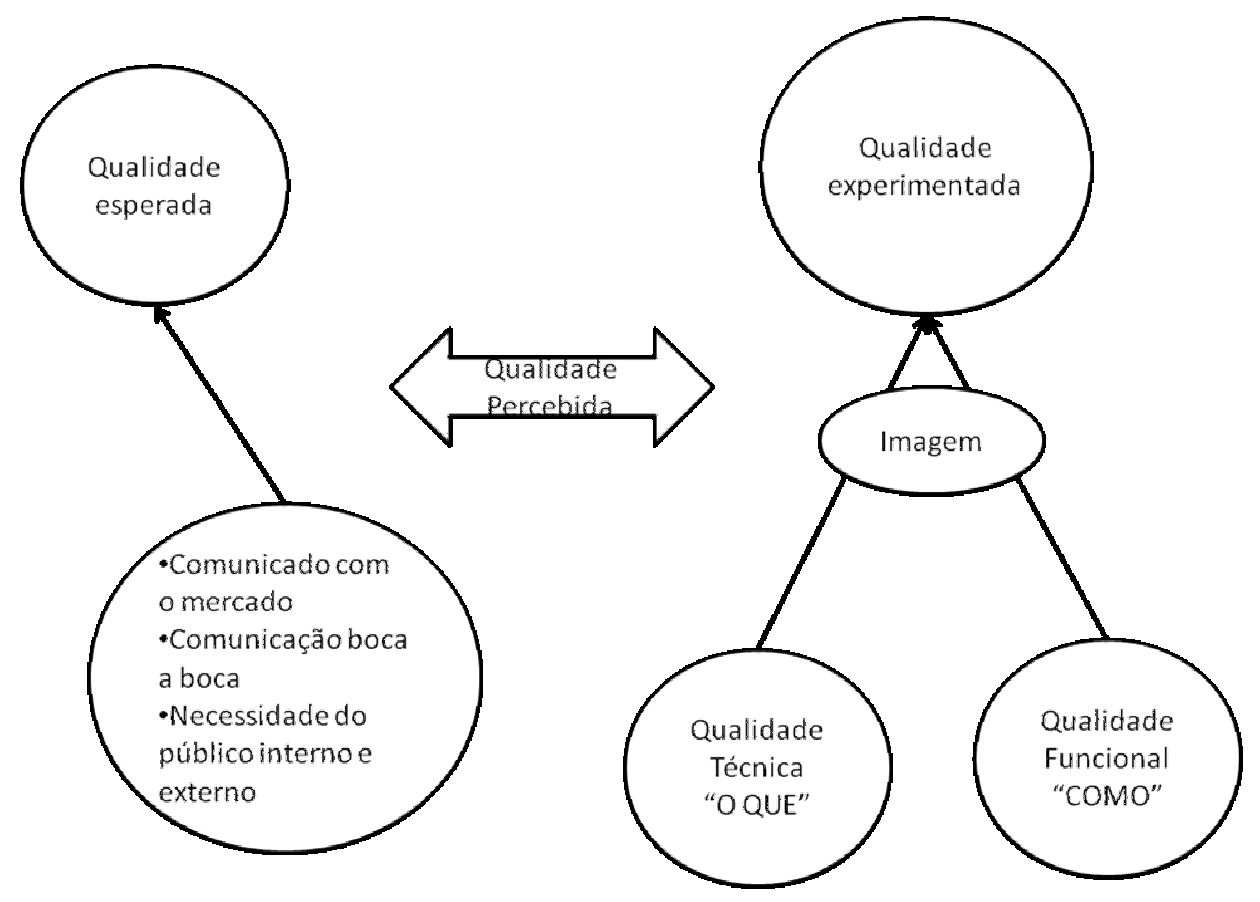

Figura 8 - Qualidade percebida

\subsubsection{Modelo de Gummerson}

O modelo de Gummerson relaciona quatro principais integrantes da qualidade: qualidade de projeto/design, qualidade de produção e entrega qualidade de relacionamento e qualidade técnica. Juntos, esses quatros componentes resultam na qualidade percebida pelo cliente, conforme mostra a figura 9. 


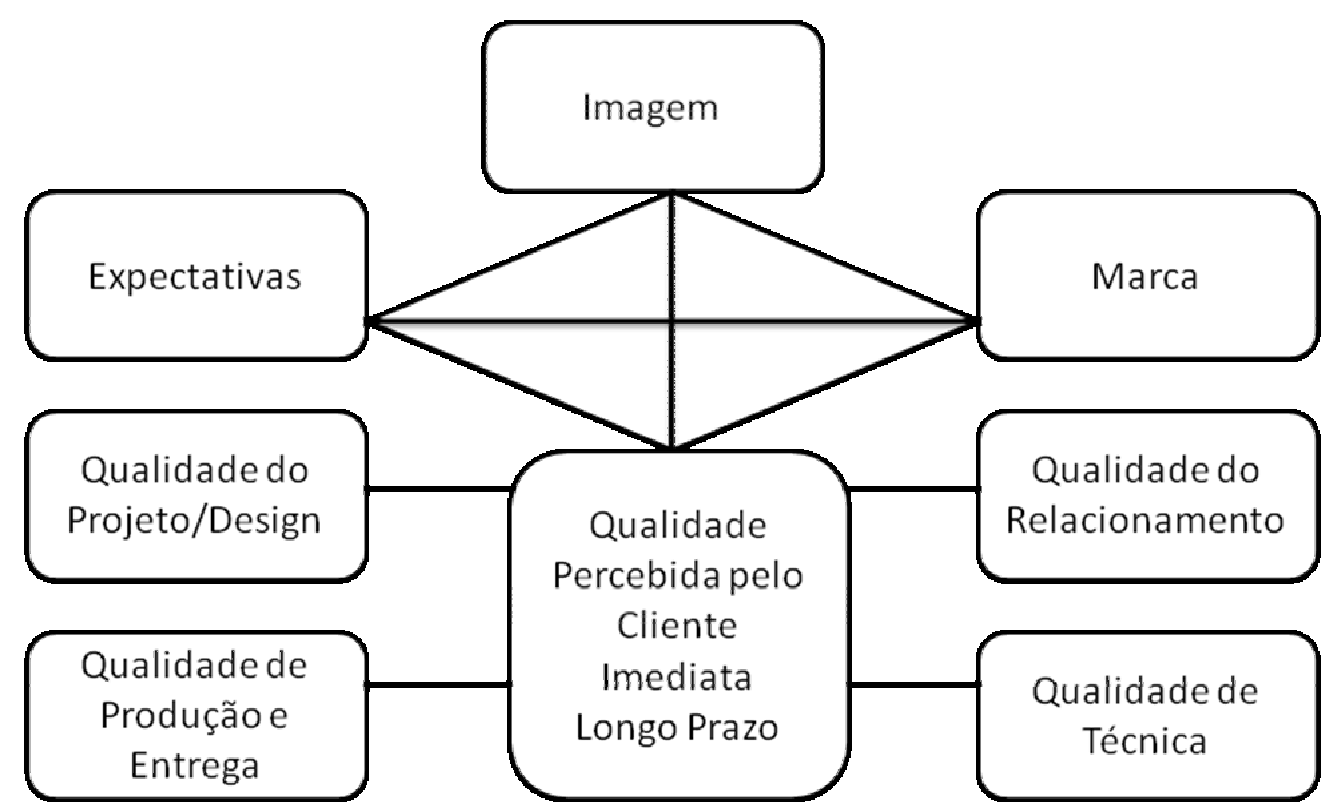

Figura 9 - Modelo de Gummerson

Para aperfeiçoar o seu modelo de qualidade (figura 9), Gronroos uniu-se a Gummerson. O modelo criado engloba a teoria da utilização do elemento marca que se refere à visão de um produto que é criado na mente do cliente, conforme mostra a figura 10 [Gronroos, Gummerson, 1988] : 


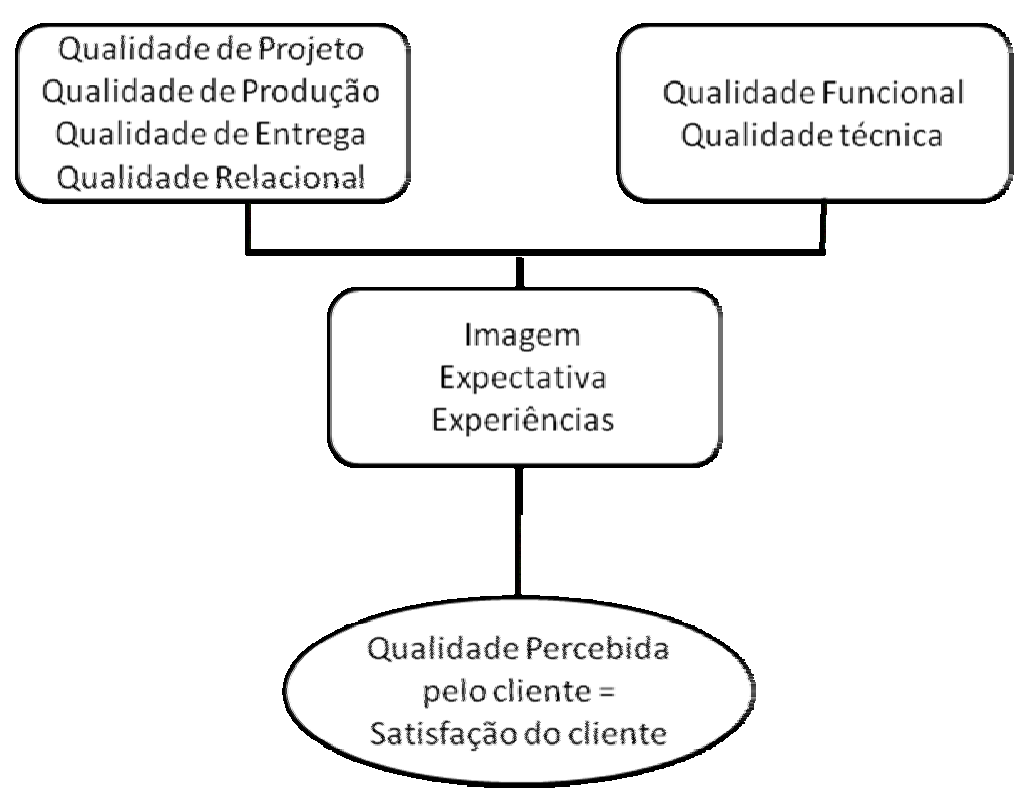

Figura 10 - Modelo de Gronroos e Gummerson

Nesse item pretendeu-se deixar claros conceitos de aceitação e qualidade, nos próximos itens serão abordados tópicos necessários para o desenvolvimento do modelo, ou seja, entender a diferença entre o consumidor, cliente e usuário. Além disso, fatores sócio-economicos, culturais entre outros que contribuiram para este trabalho.

\subsection{Entendendo os seres humanos}

Para se poder entender a aceitação de um dado serviço e a qualidade como é percebida pelo comprador, é necessário entender melhor os seres humanos. $O$ primeiro conceito importante é o da atitude no ato da compra.

Para avaliar as atitudes do comprador são utilizados métodos que servem para fixar sua posição ou reflexos de opinião em relação a um determinado produto, ou ainda, a pessoas e grupos.

Todas as pessoas são motivadas por necessidades e desejos: [McCarthy e Perreault, 1997]. 
- $\quad$ Necessidades são as forças básicas que motivam uma pessoa a fazer algo;

- Desejos: são as necessidades aprendidas durante a vida de uma pessoa.

As necessidades psicológicas surgem da necessidade de reconhecimento, autoestima ou relacionamento.

Uma necessidade torna-se um motivo, ou impulso, quando aumenta de intensidade e se torna suficientemente premente, a ponto de levar uma pessoa a buscar sua satisfação.

Sobre a motivação humana vale destacar duas mais populares teorias a primeira delas é a Teoria da motivação de Freud e a segunda a de Maslow, como descritas abaixo [ Kotler e Armstrong,1993].

\subsubsection{Consumidor, cliente e usuário.}

Para a realização deste trabalho foi preciso estudar a quem o produto é destinado. Ou seja, o ser humano pode assumir diferentes funções durante a escolha de um serviço ou produto. Por exemplo:

- Um usuário é obrigado a utilizar o produto ou serviço independentemente de sua escolha, como nos casos em que ele possua ou desfrute de alguma coisa pelo direito de uso, que sirva para o seu uso ou o empregado da empresa que é obrigado a utilizar um sistema comprado pela empresa.

- Um cliente é um indivíduo que procura proteção na competência de um profissional, como um advogado ou um médico. Um cliente procura uma determinada loja por entender que a loja o ajudará a escolher o produto correto, independentemente do fabricante.

- Um consumidor é aquele que pode decidir se quer ou não determinado produto ou serviço para uso próprio. Um consumidor pode decidir comprar ou não, ou ainda, comprar do concorrente.

A referência Kother e Armstrong descreve alguns fatores que influenciam a tomada de decisões e o comportamento do ser humano, entre eles [Kother e Armstrong ,1993]:

a) Motivações: Os seres humanos podem ser influenciados por necessidades, que são divididas em fisiológicas (fome, sede, desconforto) e psicológicas 
(reconhecimento, auto-estima, relacionamento), mas, muitas vezes, essas necessidades não serão fortes o bastante para motivar a pessoa a agir num dado momento, ou seja, a pessoa, às vezes, necessita de um motivo maior para buscar sua satisfação;

b) Personalidade: É a personalidade de cada pessoa que vai determinar o seu comportamento no ato da compra, pois se refere a características psicológicas que conduzem uma resposta relativamente consistente no ambiente em que a pessoa está inserida. $\mathrm{O}$ autor destaca, ainda que o conhecimento da personalidade pode ser muito útil para analisar o comportamento do consumidor quanto a uma marca ou um produto.

c) Percepções: Considerada como "processo pelo qual as pessoas selecionam, organizam e interpretam informações para formar uma imagem significativa do mundo".

O autor relata que os fatores situacionais também têm grande poder de influenciar o ato da compra. O ambiente agradável e confortável, por exemplo, pode determinar a compra. Outro fator que também leva em consideração os fatores situacionais é a comunicação, pois o uso de diferentes tipos de mídia por parte das empresas, com estratégias direcionadas, leva a um efeito significativo no comportamento da compra.

\subsubsection{Situação Socioeconômica}

Marx, Weber e outros autores desenvolveram o conceito de classes sociais. Para Weber classe social é um agrupamento que se define por interesses comuns no mercado e como tais interesses são diversificados, não há como deixar de admitir pluralidade das classes sociais, definidas como classes de aquisição e classes proprietárias [Marx, Weber et al apud Galliano, 1981].

Kolasa usa o conceito de classe social como sendo um grupamento de indivíduos numa hierarquia e Kotler define classe social como "divisões relativamente homogêneas e duradouras de uma sociedade, que são ordenadas hierarquicamente 
e cujos membros compartilham valores, interesses e comportamento similares"[Kotler, 1998].

Schiffman e Kanuk afirmam que o conceito de classe social implica uma hierarquia em que os indivíduos, na mesma classe, têm o mesmo status, enquanto os membros de outras classes têm status superior ou inferior [Schiffman e Kanuk, 2000].

Segundo Gade as sociedades são estratificadas, divisão que resulta nas classes sociais, que, por sua vez, determinam os papéis e posições dos indivíduos, e devido a isso se tem comportamentos diferenciados, inclusive em relação ao consumo: $O$ comportamento de consumo varia em função das classes sociais na rotina diária, desde a alimentação, o vestuário, o mobiliário, até o lazer; e isso se reflete em preferências por produtos e marcas, na escolha de lojas e na decisão entre crediário e poupança [Gade,1980].

Castro por sua vez, afirma: "a classe social pode ser definida como um critério de ordenação da sociedade, utilizando indicadores como poder aquisitivo, escolaridade e ocupação" [Castro, 2004].

Kother e Amstrong defendem fatores importantes para a classificação de uma classe social, tais como: renda, ocupação, educação, riqueza e outras variáveis [Kother e Amstrong, 1993]. Citando os autores:

"Cada classe social apresenta preferências distintas por produtos e marcas em relação a vestuário, imóveis, lazer e automóveis".

\subsubsection{Variáveis Sociais}

A organização, de acordo com Chiavenato, está sujeita a pressões sociais e a influências tanto do meio social quanto do cultural em que se localiza [Chiavenato,1985]. Stoner e Freeman afirmam que as variáveis sociais influenciam o comportamento do ser humano. Como exemplo, o estilo de vida, devido a mudanças no padrão, tem feito com que as pessoas procurem por produtos e serviços que gerem mais conforto e tranqüilidade. Além disso, à medida que a população cresce, observa-se que os padrões de consumo afetam o tamanho de mão-de-obra e da localização no mercado de consumo [Stoner e Freeman,1989]. 
A cultura, conforme Schiffmann é o resultado estudo de todos os aspectos de uma sociedade: idioma, conhecimento, leis, costumes, etc; que dão a essa sociedade caráter e personalidade distintos. No contexto do comportamento do comprador, a cultura é definida como "a soma total de crenças, valores e costumes aprendidos que servem para regular o comportamento de consumo dos membros de uma sociedade" [ Schiffmann, 2000].

Engel e Blackwell mostram atitudes e comportamentos dos mais variados tipos que a cultura pode influenciar: senso de espaço, comunicação e linguagem, vestimentas e aparências, etc. "Quando se tenta estudar as preferências, gostos e formas de percepção de problemas e tomada de decisão de compra, é necessário estudar antes seu tipo de cultura e seus determinantes" [Engel e Blackwell, 2000].

Weber define classe social como um agrupamento que tem interesses comuns no mercado e como tais interesses são diversificados, não há como deixar de admitir pluralidade das classes sociais, definidas como classes de aquisição e classes proprietárias [apud Galliano, 1981].

De acordo com Turne, dentro da psicologia a família é a maior fonte de socialização, ou seja, é o processo social pelo qual os indivíduos aprendem a interagir com os outros [Turner, 1999].

"Uma vez que a necessidade e o interesse por um produto normalmente variam com a idade do consumidor, as empresas descobriram que a idade é uma variável demográfica especialmente útil para segmentos distintos."[Schiffman; Kanuk, 2000]. 


\subsubsection{Variáveis Econômicas}

As tendências econômicas influenciam todas as organizações. Segundo Stoner e Freeman as mudanças estruturais que ocorrem nas organizações são grandes alterações permanentes ou temporárias nos setores da economia e variáveis econômicas significativas, enquanto as mudanças cíclicas "são oscilações no nível geral da atividade econômica" [Stoner e Freeman, 1985].

Segundo Kother, os mercados não exigem apenas pessoas, mas também poder aquisitivo, os quais são funções de quatro importantes fatores: Poupança, Renda normal, Preços e Disponibilidade de preços [Kother, 1996].

"Em uma época de crise econômica, por exemplo, os consumidores tendem a reduzir o padrão de consumo da família, restringindo-se a comprar produtos realmente essenciais, eliminando o supérfluo" [Cobra, 1997].

O consumidor não gastará toda a sua renda num só produto em virtude do princípio da utilidade marginal. Não importa quão atraente seja um produto, as unidades adicionais Ihe trarão satisfação decrescente [Kother, 1996].

\subsubsection{Variáveis Culturais}

O comportamento, conforme Gade é fortemente influenciado pela cultura e, portanto, o consumo também. Além disso, tem grande importância no comportamento de uma pessoa, e que em maior parte esse comportamento é aprendido, como é o caso das crianças, que aprendem seus valores ao crescer em de uma dada sociedade, onde Ihe são transmitidos comportamentos básicos pela sua família e por instituições, como escolas e igrejas [Gade, 1980].

Cultura é simplesmente tudo o que existe no contexto social determinado grupo de pessoas e ela se refere às características que os indivíduos do grupo têm em comum, como: a língua, os sistema de valores, as crenças [Kolassa, 1978].

Para Santos, cultura é[Santos, 2000]:

(...) o conjunto de pressupostos básicos que um grupo inventou, descobriu ou desenvolveu ao aprender como lidar com seus problemas de adaptação externa e de integração interna, e que suficientemente bem para serem 
considerados válidos e ensinados a novos membros como a forma correta de perceber, pensar e sentir, em relação a esses problemas.[Santos,2000]

Desta forma, segundo Kother e Armstrong o meio em que a pessoa vive influi no seu comportamento cultural, o que, por sua vez, influi em seu comportamento enquanto consumidor [Kother e Armstrong, 1993].

De acordo com Engel, Blackweel e Miniard os fatores culturais envolvem um complexo de valores, idéias e atitudes, além de outros símbolos significativos que permitem aos humanos se comunicarem e avaliarem-se como membros da sociedade. É através dos fatores culturais que vai ser definido o comportamento dos consumidores no ato da compra, e na forma de agir no mercado e na sua interação com o ambiente, sendo, então, de fundamental importância no ato de consumo e até mesmo no comportamento da pessoa [Engel, Blackweel e Miniard, 2000].

\subsubsection{Teoria da motivação segundo Freud}

A teoria da motivação segundo Freud considera que as pessoas não têm consciência da maioria das forças psicológicas que moldam seu comportamento. Segundo Freud, à medida que as pessoas crescem, reprimem muitos de seus impulsos, que nunca são eliminados ou perfeitamente controlados. De acordo com essa teoria, uma pessoa não compreende inteiramente suas motivações [Kotler; Armstrong, 1993].

Enquanto a teoria de Maslow, vista à seguir, se relaciona com a motivação, a teoria de Freud estabelece que motivações seriam responsáveis pela aceitação ou rejeição de produtos ou bens de consumo.

Freud assumiu que as forças psicológicas reais que moldam o comportamento das pessoas são inconscientes. 


\subsubsection{Teoria da motivação segundo Maslow}

Maslow definiu cinco níveis de necessidades ("Pirâmide de Maslow", figura 11). Segundo Kotler, Maslow queria explicar os motivos que levam pessoas a terem necessidades tão específicas em certas ocasiões. De acordo com a pirâmide, essas necessidades seguem uma hierarquia:

- $\quad$ Necessidades fisiológicas (comida, água, abrigo);

- $\quad$ Necessidades de segurança (segurança, proteção);

- $\quad$ Necessidades sociais (sensação de pertencer a um grupo, amor);

- Necessidades de estima (auto-estima, reconhecimento, status); e

- Necessidades de auto-realização (desenvolvimento e realização pessoal). [Kotler,1998].

De acordo com Karsaklian , a hierarquia apresentada na pirâmide está relacionada a uma escalonagem que é repassada à medida que a necessidade anterior é satisfeita [Karsaklian, 2000].

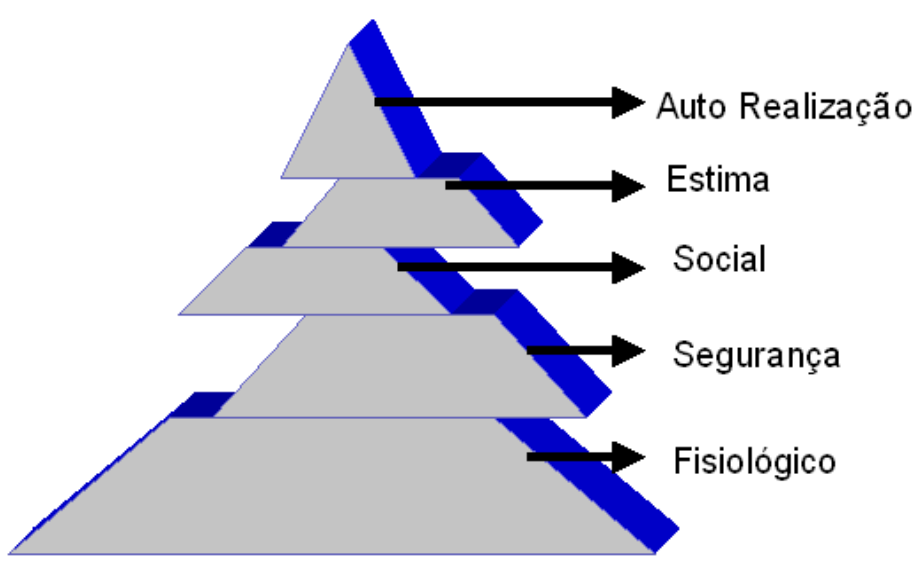

Figura 11 - Pirâmide de Maslow

Devido à evolução da informática e das telecomunicações, o mundo atual está vivendo a era do sem, ou seja, segundo Peterson, vive-se na era do fazer compra sem ir à loja, comprar sem dinheiro e trabalhar sem escritório. De acordo com o 
autor, a sociedade está sob a influência da tecnologia. Além disso, é influenciada por fatores sociais, como:

- Mudança no comportamento social: a população está ficando mais velha, aumenta o número de famílias com menos filhos, há uma maior presença da mulher no mercado de trabalho, etc;

- Impactos das mudanças: há uma menor tolerância ao tempo de resposta pois as pessoas não querem esperar, estão mais informadas, vivem em competição, etc..;

- $\quad$ Aspectos culturais: como o grau de instrução e ocupação;

- Aspectos pessoais como sexo e idade;

- Aspectos sociais e econômicos como renda, facilidade de crédito, acesso a outras mídias.

\subsection{Cognição}

Nas últimas décadas, conforme Lima, ocorreu um incremento nos estudos sobre a cognição humana, principalmente após o surgimento do computador e da modelagem computacional. A ciência cognitiva é uma área de estudos interdisciplinares que se inter-relaciona com a psicologia cognitiva, ciência da computação, sistemas de informação, inteligência artificial, neurociências e lingüística, entre outras. A partir dessa inter-relação, as pesquisas desenvolvidas sobre a cognição humana têm buscado apreender o modo como as pessoas pensam, interpretam e percebem o mundo [Lima, 2003].

Norman distingue a cognição em experimental e reflexiva. A primeira implica num estado mental no qual se percebe o que acorre ao redor e reage-se de maneira eficaz e sem esforço, basta que se atinja certo nível de perícia e envolvimento. Como exemplo, podem-se citar: dirigir automóvel, ler um livro, etc. Já a cognição reflexiva envolve o pensamento, a comparação e a tomada de decisões. Esse tipo de cognição é responsável pela criatividade e novas idéias [Norman, 1993].

Lima afirma que estudos relacionados à cognição humana ganharam maior espaço entre áreas interdisciplinares, como: psicologia cognitiva, ciência da computação sistemas de informação, inteligência artificial, neurociências e lingüística, entre 
outras. Esse espaço conquistado surgiu principalmente depois do advento do computador e da modelagem computacional; foi a partir dessa inter-relação que, as pesquisas desenvolvidas sobre a cognição humana têm buscado apreender o modo como as pessoas pensam, interpretam e percebem o mundo [Lima, 2003].

Conforme Neves, quatro teorias principais destacam-se no desenvolvimento cognitivo: a de Piaget, a neopiagetiana, a de Vygotsky e a abordagem do processamento da informação [Neves,2006].

De acordo com Miller, Sternberg e Piaget, a cognição humana é uma forma de adaptação biológica na qual o conhecimento é construído aos poucos a partir do desenvolvimento das estruturas cognitivas que se organizam de acordo com os estágios de desenvolvimento da inteligência. Assim, o desenvolvimento cognitivo está ligado aos processos de assimilação e acomodação que promovem o equilíbrio que varia de acordo com a idade [P.H. e Miller, S.A. ,1999, Sternberg ,2000 e Piaget 1983].

Os teóricos neopiagetianos, tomando por base as teorias de Piaget, dão ênfase às habilidades cognitivas, como o processar e coordenar elementos que possibilitam a diferenciação de informações na determinação de subjetivos para atingir uma meta. Além disso, incluem o conceito de mediação e interação na solução de problemas.

Em Vygotsky, entretanto, o conhecimento é construído durante as interações entre os indivíduos em sociedade, desencadeando o aprendizado. Assim, o processo de mediação se estabelece quando duas ou mais pessoas cooperam em uma atividade, possibilitando uma reelaboração [Vygotsky,1998]. Nesse sentido, conforme Miller os adultos que proporcionam modelos de comportamento, organizam e estruturam a participação das crianças em atividades, são denominados "incentivadores cognitivos" na "participação orientada" [PH e Miller, S.A , 1999]

Existem muitos diferentes tipos de cognição. Além disso, ela foi descrita no que diz respeito a tipos específicos de processos, como:

- $\quad$ Atenção;

- Percepção e reconhecimento;

- Memória;

- $\quad$ Aprendizado;

- Leitura, fala e audição;

- $\quad$ Resolução de problemas, planejamento, raciocínio e tomada de decisões. 
Johnson-Laird afirma que o objetivo da ciência cognitiva é explicar como funciona a mente [Johnson-Laird, 1988]. Segundo Casti a ciência cognitiva surgiu como um "amálgama da psicologia, filosofia, antropologia, neurofisiologia, ciência da computação e lingüística organizadas em torno do uso do computador como uma ferramenta para extrair os segredos do cérebro e da mente" [Casti ,1989].

\subsection{Modelos Mentais}

A psicologia cognitiva postula, conforme Craik, que os modelos mentais são construções internas de algum aspecto do mundo físico que são manipuladas possibilitando que previsões e interferências sejam feitas [Craik, 1943]. Conforme Johnson-Laird esse processo envolve o "desenvolvimento" e a "execução" de um modelo mental o que pode compreender tanto processos mentais conscientes como inconscientes, nos quais imagens e analogias são ativadas [Johnson-Laird, 1983].

A abordagem mais conhecida, segundo Card, é o modelo do processador humano, que modela os processos cognitivos de um usuário interando com um computador. Esse modelo é baseado no modelo de processamento de informação: a cognição é conceituada como uma série de fases de processamento, nas quais os processadores perceptuais, cognitivos e motores são organizados uns com relação aos outros [Card et al. ,1983].

O modelo prevê quais processos cognitivos estão envolvidos quando um usuário interage com um computador, o que permite calcular quanto tempo ele irá levar para realizar as tarefas, o que pode ser muito útil ao serem comparadas interfaces diferentes.

De acordo com Borges, a habilidade de um indivíduo em explicar e prever eventos e fenômenos que acontecem à sua volta evolui à medida que ele adquire modelos mentais mais sofisticados dos domínios envolvidos. Tais modelos evoluem como desenvolvimento psicológico e com a instrução, num processo conhecido como mudança conceitual [Borges,1999]. 
Conforme Johnson-Laird, Modelo Mental é o conjunto de proposições que podem levar a mais de um modelo e simulam o mundo que nos rodeia e o estado de coisas que faz parte da realidade [Johnson-Laird ,1983].

Segundo Eysenck \& Keane e Seternberg, entre outros, os modelos mentais mais utilizados são os seguintes[Eysenck e Keane,1994 e Seternberg, 2000]:

- $\quad$ esquemas: estruturas cognitivas relacionadas a um conjunto de conhecimentos armazenados em seqüência temporal ou causais, em que são mantidos os conjuntos de características dos objetos e seres. Por exemplo: procedimentos para fazer funcionar um aparelho;

- planos: conjunto de conhecimentos sobre o modo de agir para atingir determinados objetivos. Por exemplo: como fazer para vencer uma partida de xadrez;

- roteiros ou scripts: ações estereotipadas e predeterminadas aplicadas a situações definidas. Por exemplo, o roteiro aplicado quando se vai ao cinema ou a um restaurante;

- $\quad$ superestruturas ou esquemas textuais: conjunto de conhecimentos adquiridos à proporção que se lêem diversos tipos de textos e efetua-se a correlação entre eles.

Esses conjuntos de ações cognitivas são tratados separadamente para melhor compreensão da sua atuação. Entretanto, são utilizados simultaneamente, não existindo divisão em seu uso, mesmo que não se tome conhecimento consciente desses atributos. Esses modelos mentais são determinados culturalmente e apreendidos a partir da vivência em sociedade. 


\subsection{Conceitos de Usabilidade ${ }^{1}$}

O termo usabilidade tem sido muito utilizado pelo meio da computação, em sua área de estudo da interface humano-máquina, como sendo a facilidade de uso de um determinado software pelo usuário. Nesse trabalho procurou-se utilizar os conceitos e ferramentas definidas naquela área do conhecimento, sendo que termo foi espandido para facilidade de uso de qualquer equipamento ou serviço.

O referencial teórico forneceu importantes subsídios para compreender quais os processos que estão envolvidos na interação física e na interação cognitiva do ser humano com todo o sistema computacional.

Segundo Nielsen, um dos principais pesquisadores sobre usabilidade definiu-a como "uma medida da qualidade da experiência do usuário ao interagir com alguma coisa - seja um site na Internet, um aplicativo de software tradicional, ou outro dispositivo que o usuário possa operar de alguma forma" [Nielsen, 1998].

Shakel, Nielsen e Jordan em seus estudos referentes à usabilidade criaram modelos de usabilidade conforme podem ser vistos a seguir [Shackel,1991; Nielsen,1998;Jordan ,1998].

\subsubsection{Usabilidade segundo Shackel}

Segundo Shackel a Usabilidade é um dos componentes da aceitabilidade conforme ilustra a figura 12. Para o pesquisador, a utilidade refere-se à combinação entre as necessidades do usuário e as funcionalidades do produto. A Usabilidade em seu ponto de vista refere-se à habilidade do usuário em poder utilizar essas funcionalidades na prática e a a agradabilidade se refere à avaliação afetiva por parte do usuário e o custo inclui não só o custo financeiro mas também as conseqüências do relacionamento com o produto [Shackel, 1991].

\footnotetext{
${ }^{1}$ O termo usability, também referido como useability ou usableness, possui definições genéricas em dicionários correntes da língua inglesa, do tipo "qualidade do que é aproveitável, usável". A tradução desse termo para a língua portuguesa como usabilidade, um neologismo técnico, baseou-se em dois fatos: (i) em português, a terminação inglesa -ility se faz corresponder, em diversas situações, ao sufixo -ilidade; e (ii) da aplicação da regra portuguesa de substantivação de adjetivos terminados em ável (e.g., miserável - miserabilidade, afável - afabilidade).
} 


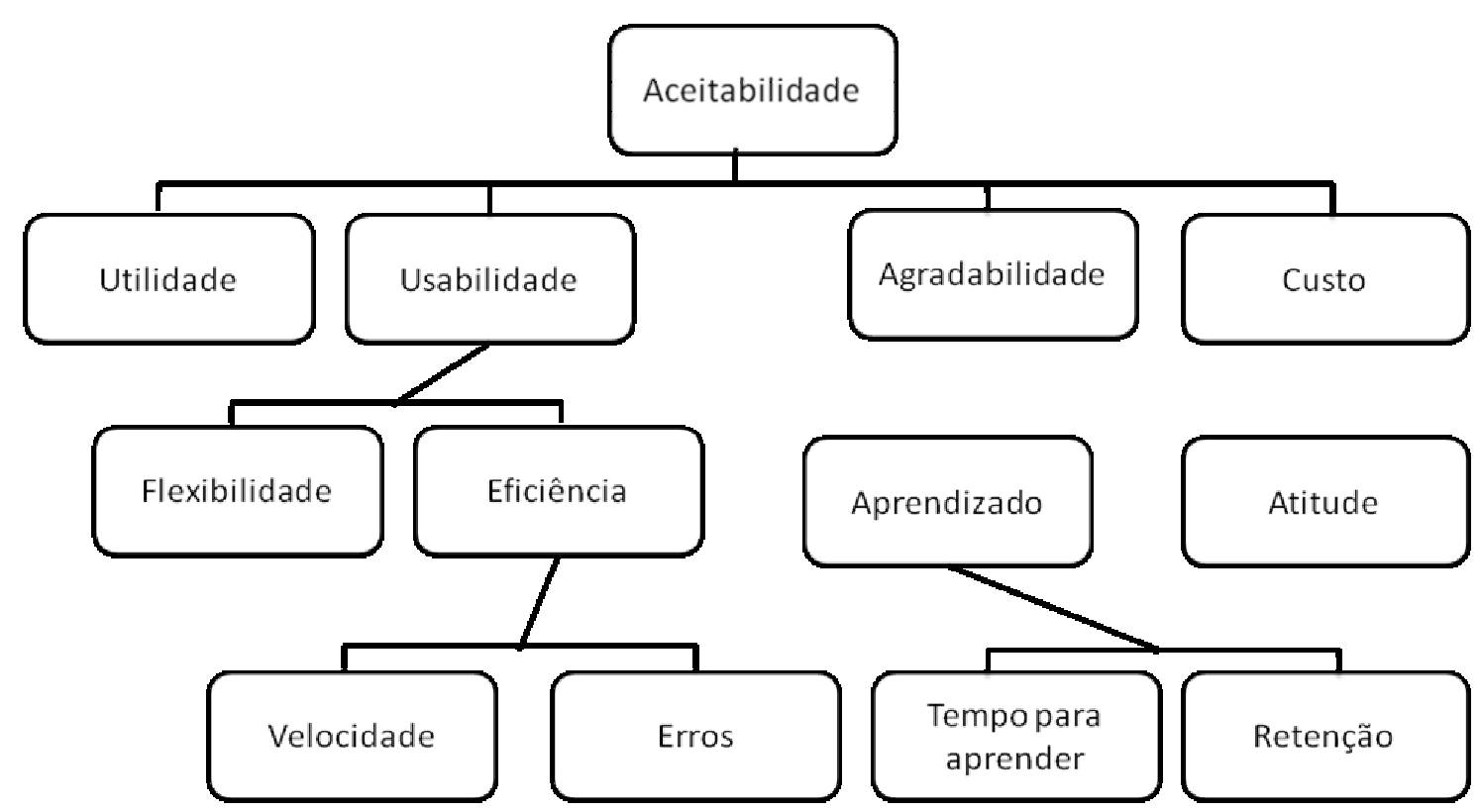

Figura 12 - Modelo de atributos de aceitabilidade de um sistema segundo Shackel Fonte: Shackel, 1991.

\subsubsection{Usabilidade segundo Jordan}

Jordan define Usabilidade com base em três componentes: intuitividade, aprendizagem e desempenho do usuário experiente. Algum tempo depois, houve a adição de mais dois componentes: potencial do sistema e re-usabilidade. Esses componentes são definidos como [Jordan, 1998]:

- Intuitividade: Refere-se ao custo para o usuário; consiste no tempo e na taxa de erro, quando ele, por exemplo, utiliza o produto pela primeira vez;

- Aprendizagem: Desconsiderando as dificuldades que são peculiares na realização de uma tarefa pela primeira vez, avalia-se o nível de competência do usuário ao realizar determinada tarefa;

- Desempenho do usuário experiente (PUE): Consiste no nível do desempenho atingido pelo usuário ao realizar, muitas vezes, determinadas tarefas com um determinado produto;

- Potencial do sistema: É o limite máximo do PUE que pode ser atingido ao realizar uma determinada tarefa com um produto; 
- Re-usabilidade: Indica uma possível diminuição do desempenho que pode ocorrer após um intervalo de tempo sem uso.

De acordo com Jordan, a usabilidade não pode ser considerada isoladamente, ela faz parte da interação entre o produto, o usuário, a tarefa que ele está tentando executar e o ambiente que o cerca [Jordan, 1998].

\subsubsection{Usabilidade segundo Nielsen}

O conceito de Usabilidade de acordo com Nielsen é algo mais amplo, uma vez que ele enfatiza que a Usabilidade envolve aspectos como custo, confiabilidade e aceitabilidade social, como mostra a figura 13 [Nielsen, 1993]:

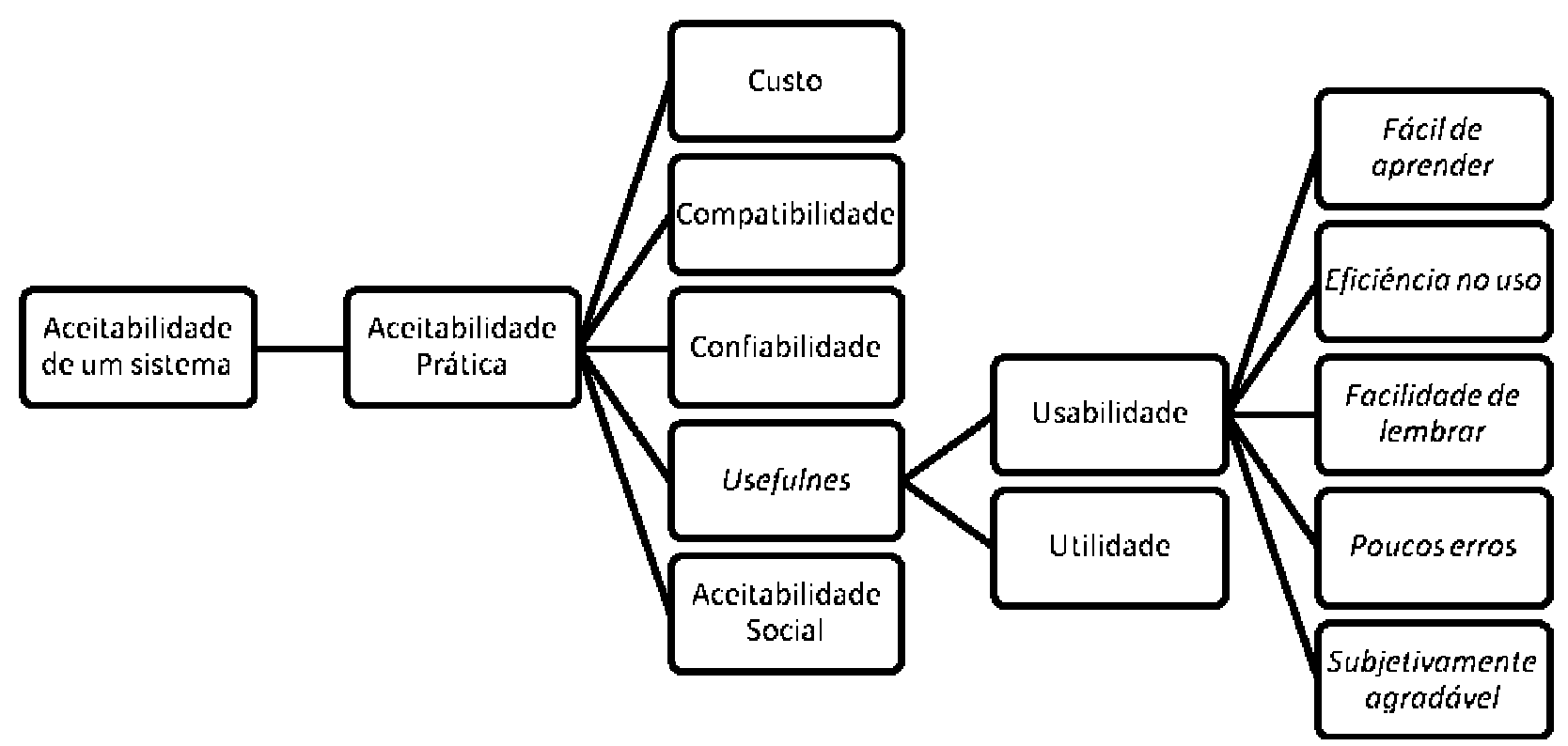

Figura 13 - Modelo de atributos de aceitabilidade de um sistema segundo Nielsen Fonte: Nielsen, 1993. 
O autor define os cinco atributos de aceitabilidade de um sistema como:

- Eficiência no uso: assim que o usuário aprenda a utilizar o sistema, as utilizações futuras têm que ter alta produtividade;

- Facilidade de aprendizagem: o sistema deve ser de fácil assimilação, ou seja, quando o usuário fica um determinado tempo sem utilizar o sistema, ele não tem necessidade de aprender todo o processo novamente;

- Poucos erros: erros de operação são inevitáveis, por esse motivo, quando o usuário comete algum erro, ele deve ter a possibilidade de recuperar o estado inicial imediatamente;

- Subjetivamente agradável: o usuário deve ficar satisfeito com o uso, não pode experimentar desconforto ao utilizar o sistema.

Nielsen, ainda, afirma que medir a usabilidade é algo importante no ciclo da Engenharia de Usabilidade, pois ela permite verificar se os objetivos de usabilidade desejados foram efetivamente atingidos e também para comparar a usabilidade entre produtos concorrentes[Nielsen,1993]. O modelo pode ser visto na figura abaixo.

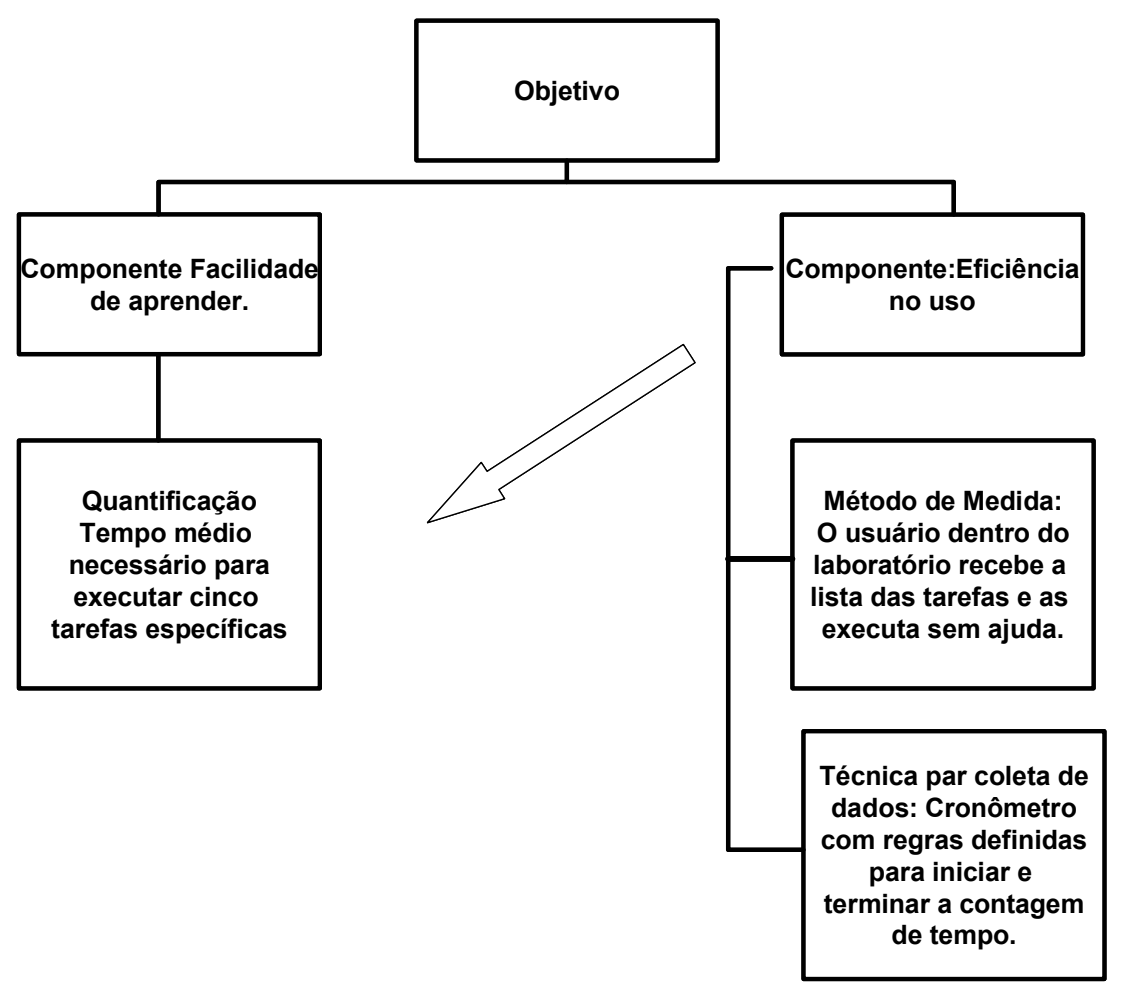

Figura 14 - Modelo de medida da usabilidade segundo Nielsen

Fonte: Nielse, 1993. 
Com base nos estudos citados e com a análise das ferramentas utilizadas para avaliações de modo geral, o próximo capítulo abordará os métodos de avaliação da usabilidade que contribuíram para o desenvolvimento do modelo proposto, tais como: Observações, Questionários (QUIS e SUS), Avaliação Heurística e etc.. 


\section{MÉTODOS DE AVALIAÇÃO}

Esse capítulo apresenta os métodos utilizados na avaliação da usabilidade, dentre eles têm-se: a observação, os diversos tipo de questionários, a avaliação heurística, entre outros. O modelo de avaliação de aceitabilidade de serviços foi desenvolvido através dos estudos, adaptações e modificações desses métodos.

Avaliações são necessárias durante o processo de design e desenvolvimento de um produto, elas auxiliam na eliminação de variadas dúvidas surgidas nesse momento. Pode-se dizer que a avaliação direciona e se mescla com o design, apoiando a criação de um produto útil e utilizável. A avaliação pode ser utilizada para:

- $\quad$ Avaliar a funcionalidade do sistema;

- $\quad$ Avaliar o efeito da interface junto ao usuário;

- Identificar problemas específicos do sistema.

De acordo com Baranauskas e Rocha classificam as avaliações em dois grupos:

- Inspeção de usabilidade: em que os usuários podem ou não estar envolvidos em qualquer fase do desenvolvimento de um sistema (implementado ou não);

- Testes de usabilidade: tratam dos métodos de avaliação centrados nos usuários que incluem métodos experimentais ou empíricos observacionais e técnicas de questionamento. Nesse caso, é necessária a existência de uma implantação real do sistema, em algum formato, que pode ser desde uma simulação da capacidade interativa do sistema, sem nenhuma funcionalidade, um protótipo básico implementado, um cenário ou até a implementação completa. [Baranauskas e Rocha, 2000].

Winckler, por sua vez, apresenta vários aspectos na classificação da avaliação [Winckler, 1999]. Dentre estes critérios, destacam-se:

- Participação de usuários: nesse caso, nem todas as técnicas contam com a participação de usuários. Eles, por sua vez, podem ser reais ou representativos. Os usuários reais são aqueles que de fato utilizam o sistema ou correspondem ao público-alvo dele, enquanto os representativos possuem características correlatas ao público-alvo, mas não fazem parte dele 
diretamente. Portanto, por exemplo, quando não for possível trazer usuários reais para os testes, podem-se utilizar usuários representativos;

- Agente identificador do problema: corresponde à pessoa que identifica o problema. Ainda, segundo Winclker, "a relevância desta classificação é expressa na qualidade da descrição do problema e confiança sobre ela, em situações reais de trabalho". Quando os problemas são identificados apenas por usuários, apresentam características de problemas reais, ocorridos durante a manipulação da interface e, por isso, indicam que esses afetam a realização de suas tarefas ou frustram suas expectativas. Quando a identificação é feita por avaliadores, a descrição do problema é mais detalhada e, geralmente, aponta soluções [Winclker, 1999]:

- $\quad$ Tipo de tarefa analisada: são distinguidos dois tipos de tarefas: as reais, que comportam qualquer tarefa que o usuário possa realizar com a interface; e as representativas, predefinidas pelo avaliador, que limitam a avaliação dessas tarefas específicas sobre a interface.

Nielsen, por sua vez sumariza quatro etapas de um ensaio de usabilidade típico:

- Preparação: Verificação de todas as condições de teste (sala, sistema computacional, material necessário em geral, instruções e instrumentos de questionamento, etc.) antes da introdução do usuário de teste no ambiente.

- Introdução: Recepção do usuário e explanação breve do(s) propósito(s) do ensaio. Introdução do(s) procedimento(s) de teste. Distribuição das instruções e esclarecimento de dúvidas.

- Testes: Observação imparcial de todos os eventos interativos usuário-sistema. Anotação, quando necessária, de detalhes pertinentes ao contexto avaliatório. Diálogo limitado ao estritamente necessário com apenas um dos avaliadores, conforme acordo prefixado.

- Questionamento/Análise de Resultados: Apresentação do mecanismo de questionamento (questionário, verbalização de procedimentos ou outra estratégia predefinida) ao usuário de teste. Associação de todas as informações coletadas (arquivos armazenados no sistema, anotações, questionários e/ou outro meio) ao usuário correspondente. Elaboração imediata de um breve relatório do ensaio. Elaboração de relatório final [Nielsen,1993]. 
Os mecanismos de avaliação mais comumente empregados em usabilidade são: observações, uso de questionários, entrevistas, verbalização de procedimentos, interação construtiva, ensaio retrospectivo, captura automática diretamente da aplicação, discussões em grupo e retorno imediato de opiniões do usuário.

Como se pode verificar, as classificações envolvem ou não a participação dos usuários, sejam eles reais ou representativos. A seguir, serão apresentadas algumas técnicas de avaliação encontradas na literatura, dentre elas: observação, questionário, avaliação heurística, entre outras.

\subsection{Observação}

Trata-se de uma técnica de coleta de dados que consiste em ver, ouvir e também examinar fatos ou fenômenos que se deseja estudar. É um elemento básico de investigação científica, utilizado na pesquisa de campo como abordagem qualitativa. Essa técnica facilita o grau de participação do observador e a duração das observações. Para isso, é preciso planejar O QUE e COMO observar.

Outra questão importante é como fazer com que a etnografia se adapte ao processo de desenvolvimento. Para isso existem quatro estágios a saber: [Preece, 2005].

- Preparação: entender as políticas de organização e cultura do trabalho; familiarizar-se com o sistema e sua história; estabelecer metas inicias e preparar as perguntas; Obter acesso e permissão para observar e entrevistar;

- Estudo de campo: Estabelecer uma boa relação com gerentes e usuários; observar e entrevistar usuários em seus locais de operação e coletar dados; seguir quaisquer pistas que emergirem de visitas e registrar as visitas.

- Análise: Compilar os dados coletados em bases de dados numéricas, textuais e multimídia; Quantificar dados e compilar estatísticas; reduzir e interpretar dados; aperfeiçoar as metas e os processos utilizados; Relatar considerando os diferentes públicos e objetivos; Preparar um relatório e apresentar os resultados.

O registro pode ser feito através de anotações, câmeras, áudio e vídeo. A tabela 1 compara as principais técnicas [Preece, 2005]. 
Tabela 1 - Comparativo das principais técnicas

\begin{tabular}{|c|c|c|c|}
\hline Critério & Anotação e câmera & Áudio e câmera & Vídeo \\
\hline Equipamento & $\begin{array}{l}\text { Papel, lápis, câmera são } \\
\text { facilmente encontrados }\end{array}$ & $\begin{array}{l}\text { Gravador barato, portátil, } \\
\text { com um bom microfone. } \\
\text { Fones de ouvido são úteis } \\
\text { para facilitar a transcrição }\end{array}$ & $\begin{array}{l}\text { Mais caro. Equipamentos } \\
\text { de edição, mixagem e } \\
\text { análise são necessárias. }\end{array}$ \\
\hline $\begin{array}{l}\text { Flexibilidade } \\
\text { de uso }\end{array}$ & xível. Discreto & $\begin{array}{l}\text { Flexível. } \\
\text { discreto. }\end{array}$ & $\begin{array}{l}\text { É necessário posicionar e } \\
\text { focalizar as lentes da } \\
\text { câmera. Mesmo os } \\
\text { equipamentos portáteis } \\
\text { podem ser volumosos }\end{array}$ \\
\hline dades & $\begin{array}{l}\text { Conta somente com o } \\
\text { que a pessoa que está } \\
\text { anotando pensa que é } \\
\text { importante e r pode } \\
\text { registrar no tempo } \\
\text { disponível . problemas } \\
\text { com avaliadores } \\
\text { inexperientes. }\end{array}$ & $\begin{array}{l}\text { Pode-se obter } \\
\text { gravação completa de } \\
\text { áudio, mas os dados visuais } \\
\text { ficam de fora, anotações, } \\
\text { fotografias, desenhos } \\
\text { podem somar-se aos } \\
\text { registros, mas precisam ser } \\
\text { coordenados com a } \\
\text { gravação de fita. }\end{array}$ & $\begin{array}{l}\text { O método mais completo } \\
\text { de coleta de dados, } \\
\text { especialmente se for } \\
\text { utilizada mais de uma } \\
\text { câmera; no entanto, é } \\
\text { necessário coordenar o } \\
\text { material gravado. }\end{array}$ \\
\hline $\begin{array}{l}\text { Atrapalha } \\
\text { usuários }\end{array}$ & & $\begin{array}{l}\text { Pouco, mas haverá } \\
\text { interrupções para se } \\
\text { trocarem as fitas } \\
\text { posicionar o microfone. } \\
\end{array}$ & $\begin{array}{l}\text { Pode ser muito invasivo. } \\
\text { É preciso ter cuidado para } \\
\text { evitar o efeito Hwathorne. }\end{array}$ \\
\hline $\begin{array}{l}\text { Dilidade } \\
\text { dos. }\end{array}$ & $\begin{array}{l}\text { Pode ser } \quad \text { baixa. } \\
\text { Depende de se fazer } \\
\text { uma boa gravação e de } \\
\text { se saber o que registrar. }\end{array}$ & $\begin{array}{l}\text { Alta, mas ruídos externos, } \\
\text { como os dos ventiladores } \\
\text { dos computadores, podem } \\
\text { abafar o som. }\end{array}$ & $\begin{array}{l}\text { Podem ser alta, mas } \\
\text { depende do que a câmera } \\
\text { está focalizando. }\end{array}$ \\
\hline e & $\begin{array}{l}\text { Relativamente fácil de } \\
\text { transcrever. Podem-se } \\
\text { produzir descrições } \\
\text { ricas. Transcrever dados } \\
\text { pode ser oneroso ou um } \\
\text { primeiro passo bastante } \\
\text { útil na análise dos } \\
\text { dados. }\end{array}$ & $\begin{array}{l}\text { Discussões criticas podem } \\
\text { ser identificadas. É } \\
\text { necessário transcrever para } \\
\text { obter uma análise mais } \\
\text { detalhada. Material de } \\
\text { registro original permanente } \\
\text { que pode ser consultado. }\end{array}$ & $\begin{array}{l}\text { Problemas críticos pode } \\
\text { ser identificados e e } \\
\text { rotulados. } \quad \text { Suporte } \\
\text { automatizado necessário } \\
\text { para uma análise } \\
\text { detalhada. Material de } \\
\text { registro } \quad \text { original } \\
\text { permanente que pode ser } \\
\text { consultado. }\end{array}$ \\
\hline $\begin{array}{l}\text { Feedback } \\
\text { para equipe } \\
\text { de design }\end{array}$ & $\begin{array}{l}\text { aseia-se muito na } \\
\text { utoridade do avaliador. }\end{array}$ & $\begin{array}{l}\text { Material captado em fita é } \\
\text { mais convincente do que } \\
\text { anotações, mas o feedback } \\
\text { baseia-se na autoridade do } \\
\text { avaliador }\end{array}$ & $\begin{array}{llr}\text { É difícil discutir } & \text { sobre } \\
\text { material captado } & \text { em } \\
\text { vídeo. Videoclipes } & \text { são } \\
\text { muito bons } & \text { para } \\
\text { comunicar idéias. } & \\
\end{array}$ \\
\hline
\end{tabular}

\subsection{Questionários}

A aplicação de questionários foi muito útil no desenvolvimento desta tese, pois, de acordo com Nielsen a sondagem da satisfação subjetiva do usuário, a partir da aquisição de informações sobre a sua opinião acerca do sistema, afigura-se como 
uma estratégia alternativa bastante atrativa. Solicitar aos usuários sua opinião através da aplicação de questionários tem sido uma estratégia bastante empregada em diversos âmbitos de interesse. Se, do ponto de vista de um único usuário, as implicações de tal procedimento podem adquirir uma conotação puramente subjetiva, quando se pondera as opiniões de múltiplos usuários os resultados passam a se enquadrar num contexto objetivo mais amplo [Nielsen, 1993].

Conforme Nielsen os questionários ganharam uma dimensão extra como ferramentas avaliatórias, principalmente quando se trata de estudos que envolvam diretamente a satisfação do usuário e/ou que visem respostas sobre como os usuários interagem com os sistemas e quais as características que particularmente os satisfazem ou desagradam [Nielsen, 1993].

De acordo com Queiroz, a aplicação de questionários como instrumentos de coleta de dados permitem, antes de tudo, a focalização direta do tema de interesse, possibilitando o controle do grau de especificidade almejado para a investigação e a aquisição de dados homogêneos fornecidos pela categoria de indivíduos adequada ao contexto da pesquisa [Queiroz, 2001].

Dentre os questionários mais utilizados têm-se QUIS, ASQ, SUS, entre outros como descritos a seguir.

\subsubsection{Questionnaire for User Interaction Satisfaction (Quis)}

O QUIS foi desenvolvido por uma equipe multidisciplinar de pesquisadores do Human-Computer Interaction Lab (HCIL) da University of Maryland. Composto por 80 itens, o QUIS foi elaborado para sondar a satisfação, aspecto da usabilidade de produtos de software [Ching et al.,1988].

O QUIS é formado por uma escala numérica de nove pontos delimitada por adjetivos positivos à direita e negativos à esquerda. Adicionalmente, a cada item é oferecida a opção not applicable (não aplicável, assim como um espaço que permite a inclusão de comentários). O quadro abaixo ilustra o QUIS em seu formato HTML.

Hierarquicamente organizado em sete fatores referentes à interface:

- $\quad$ Fatores relacionados às telas;

- $\quad$ Terminologia e retorno do sistema; 
- $\quad$ Fatores relacionados ao aprendizado;

- Capacidade do sistema;

- Manuais técnicos;

- Tutoriais on-line;

- $\quad$ Multimídia.

\begin{tabular}{|llll|}
\hline 5.4 Messagens withich appear on screen confusing & \multicolumn{3}{c|}{ clear } \\
& 123456789 & NA \\
5.4.1 Instruction for commands or choice confunsing 123456789 & NA & clear & \\
\hline
\end{tabular}

(a)

Characters on the computer screen

hard to read

$\begin{array}{llllllll}010203040506070809 & O N A\end{array}$

Image of characters

fuzzy sharp

NA

01020300405060070809

0

Character shapes (fonts)

barely legible very legible

010203040506070800

0

NA

Reset

(b)

Quadro 1 - Excertos do QUIS (Questionnaire for User Interaction Satisfaction): (a) versão impressa e (b) versão HTML.

FONTE: http://lap.umd.edu/QUIS/

\subsubsection{System Usability Scale (SUS)}

Desenvolvido em 1986 por John Brook, o SUS foi elaborado como uma escala de usabilidade contendo dez questões. Sua criação fez parte da introdução de um programa de usabilidade na Digital Equipment Co. Ltd. (DEC - Reading, UK), focalizando sistemas integrados destinados ao trabalho em escritórios. 
Conforme o autor, cada item contém uma declaração relativa ao aspecto de interesse, que é associada a uma escala numérica de cinco pontos, ladeada à esquerda por strongly disagree (discordo totalmente) e à direita por strongly agree (concordo totalmente), conforme ilustrado na figura 15 [Brook, 1996]:

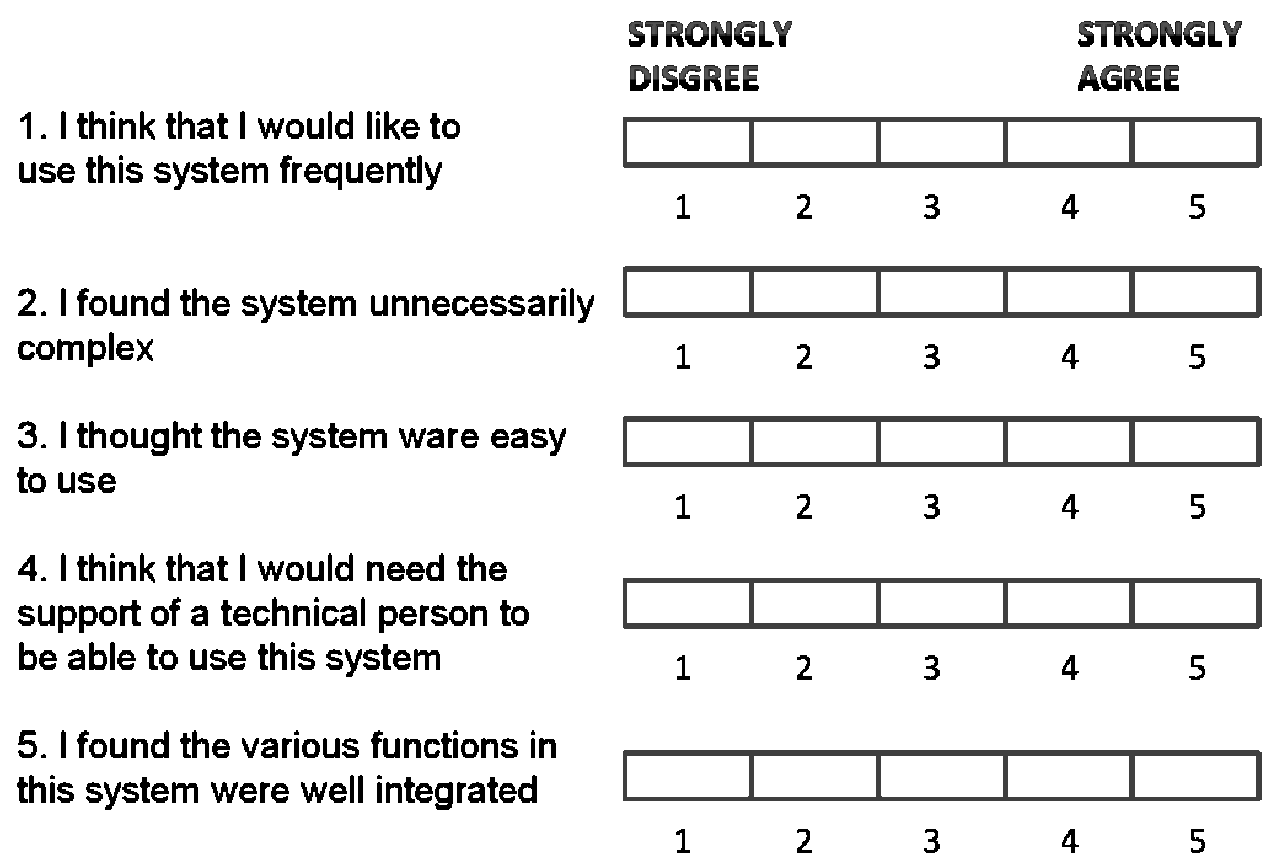

Figura 15 - Trecho do questionário SUS

\subsubsection{Avaliação Heurística}

A avaliação heurística é um método analítico que visa identificar problemas de usabilidade conforme um conjunto de heurísticas ou diretrizes (guidelines). [Nielsen, 1994]. Baseia-se em melhores práticas definidas por profissionais experientes e especialistas em IHC.

A avaliação heurística, pode ser usada durante todo o ciclo de desenvolvimento do produto [Nielsen,1994]. As regras desse método conduzem à descoberta, à criação, à resolução de problemas e ajudam a traçar diretrizes para a concepção de sistemas. 
A aplicação dessa avaliação não engloba o envolvimento de usuários e deve ser realizada por avaliadores especialistas, em geral, de três a cinco especialistas.

O processo segue de forma individual e, durante a sessão de avaliação, cada avaliador percorre a interface pelo menos duas vezes; inspecionam-se os diferentes componentes de diálogo ao localizar problemas, estes por sua vez, devem ser relatados e associados nitidamente, segundo as regras heurísticas de usabilidade. Segundo Nielsen, as heurísticas baseiam-se em regras gerais que visam descrever prioridades comuns em interfaces utilizáveis (Quadro 02) [Nielsen,1994]. 
1) Visibilidade do status do sistema: $O$ sistema precisa manter os usuários informados sobre o que está acontecendo, fornecendo um feedback adequado dentro de um tempo razoável.

2) Compatibilidade do sistema com o mundo real: $O$ sistema precisa falar a linguagem do usuário, com palavras, frases e conceitos familiares ao usuário, em vez de termos orientados ao sistema. Seguir convenções do mundo real, fazendo com que a informação apareça numa ordem natural e lógica.

3) Controle do usuário e liberdade: Usuários freqüentemente escolhem por engano funções do sistema e precisam ter claras saídas de emergência para sair do estado indesejado, sem ter que percorrer um extenso diálogo. Prover funções undo e redo.

4) Consistência e padrões: Usuários não precisam adivinhar que diferentes palavras, situações ou ações significam a mesma coisa. Seguir convenções de plataforma computacional.

5) Prevenção de erros: Melhor que uma boa mensagem de erro é um design cuidadoso o qual previne o erro antes dele acontecer.

6) Reconhecimento ao invés de relembrança: Tornar objetos, ações e opções visíveis. O usuário não deve ter que lembrar informação de uma outra parte do diálogo. Instruções para uso do sistema devem estar visíveis e facilmente recuperáveis quando necessário.

7) Flexibilidade e eficiência de uso: Usuários novatos tornam-se peritos com o uso. Prover aceleradores de forma a aumentar a velocidade de interação. Permitir a usuários experientes "cortar caminho" em ações freqüentes.

8) Estética e design minimalista: Diálogos não devem conter informação irrelevante ou raramente necessária. Qualquer unidade de informação extra no diálogo irá competir com as unidades relevantes de informação e diminuir sua visibilidade relativa.

9) Ajudar os usuários a reconhecer, diagnosticar e corrigir erros: Mensagens de erro devem ser expressas em linguagem clara (sem códigos), indicando precisamente o problema e construtivamente sugerindo uma solução.

10) Help e documentação: Embora seja melhor um sistema que possa ser usado sem documentação, é necessário prover help e documentação. Essas informações devem ser fáceis de encontrar, focalizadas na tarefa do usuário e não muito extensas.

\section{Quadro 2 - Heurísticas}

FONTE: Nielsen, 1994.

\subsubsection{Pensando em Voz Alta}

Segundo Baranauskas e Rocha, este teste é utilizado como um método de pesquisa psicológico [Baranauskas e Rocha 2000]. É solicitado ao usuário que verbalize todos 
seus pensamentos enquanto interage com o sistema. $O$ analista deve ser eficiente, induzindo o usuário a falar sempre, porém não deve interferir na interação. Pode-se utilizar formas de questionamento usuais, do tipo:

- Está pensando em que agora?

- Como você interpreta essa mensagem? (depois que o usuário notar a mensagem);

- $\quad$ O que você acha que vai acontecer caso faça isso? (caso o usuário pergunte se pode fazer algo);

- Você esperava que isso poderia acontecer? O que esperava? (caso o usuário se mostre surpreso).

Paralelamente, os comentários dos usuários são anotados. Também há a alternativa de incentivar o usuário a comentar suas ações gravadas em vídeo, é uma alternativa eficaz para se obter dados qualitativos do desempenho, porém, o tempo de aplicação do teste demora no mínimo o dobro.

Os estudos apresentados deram o alicerce para o desenvolvimento do modelo de avaliação de serviços convergentes em ambientes heterogêneos. O próximo capítulo descreve o ambiente e os serviços onde se pretende que o modelo seja aplicado.

\subsection{QFD Desdobramento da Função da Qualidade}

A indústria japonesa, conforme Akao, na década de 60, teve um período de grande crescimento. Com isso, a indústria automobilística começou a realizar constantes alterações de modelos e lançamento de novos veículos. O resultado desse crescimento trouxe a dificuldade de garantir a qualidade do produto desde sua fase inicial até a final. Era preciso, portanto, criar um método que garantisse a qualidade. Para solucionar esse problema, Yoji Akao, em união com Shigeru Mizuno, deram origem ao Quality Funtion Deployment (QFD) oriundo das palavras japonesas hin shitsu (qualidade, características, atributos), ki no (função, mecanização) e tem kai (desdobramento, difusão, desenvolvimento e evolução), em português traduzido para: Desdobramento da Função da Qualidade. Segundo Cortés uma das características do QFD é "levantar" a voz (tabela 2) dos clientes e traduzir em características mensuráveis, criando assim, produtos e serviços que atendam e/ou 
superem as expectativas dos clientes [Cortez,2005]. De acordo com Carnevalli, o QFD pode ser definido como uma forma de comunicar sistematicamente informação relacionada com a qualidade de explicitar ordenadamente trabalho relacionado com a obtenção da qualidade, tendo como objetivo alcançar o enfoque da garantia da qualidade durante o desenvolvimento de produto e é subdividida em desdobramento da qualidade (QD) e Desdobramento da função qualidade no sentido restrito (QFDr)". A figura 16 mostra a relação entre QFD, QD e QFDr. Com base nessa definição, O QDF pode ser classificado em duas partes QFDamplo= QD+QFDrestrito[Carnevalli, 2004].

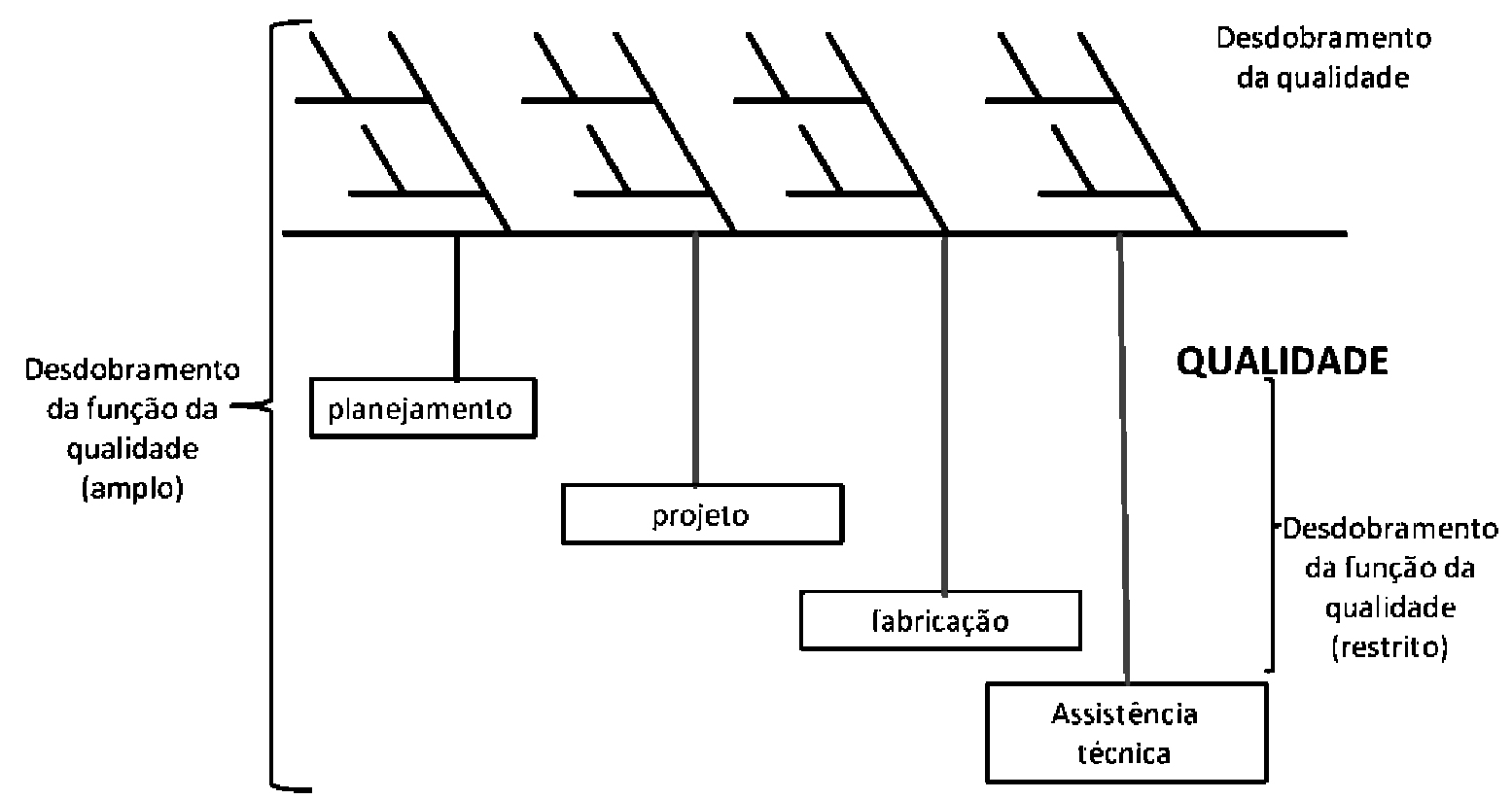

Figura 16- Relação entre QFD,QD e QFDr

Fonte: Akao, Y. (Ed), 1990

A qualidade de desdobramento tem por finalidade converter os interesses dos consumidores em características de qualidade [Barbêdo, 2004]. Enquanto QFDr é definido como um processo sistemático de desdobramento do trabalho de ação gerencial de planejamento da qualidade em procedimentos gerenciais e técnicos para serem cumpridos pelas áreas funcionais da empresa. 
Tabela 2 - Roteiro para Levantar a Voz do Cliente

\begin{tabular}{|c|c|c|c|}
\hline \multicolumn{2}{|c|}{ Etapa } & \multicolumn{2}{|c|}{ Passo } \\
\hline \multirow[t]{3}{*}{1} & \multirow{3}{*}{$\begin{array}{l}\text { Desenvolver e } \\
\text { compreender o } \\
\text { ambiente e } \\
\text { necessidades do } \\
\text { cliente }\end{array}$} & 1 & $\begin{array}{l}\text { Decidir como examinar amplamente as possíveis } \\
\text { necessidades do cliente. }\end{array}$ \\
\hline & & 2 & $\begin{array}{l}\text { Ouvir presencialmente as necessidades de clientes potenciais } \\
\text { e ver o que eles estão fazendo. }\end{array}$ \\
\hline & & 3 & $\begin{array}{l}\text { Desenvolver uma imagem do ambiente do cliente. Interagir e } \\
\text { tornar explícito o que eles estão fazendo. }\end{array}$ \\
\hline \multirow[t]{3}{*}{2} & \multirow[t]{3}{*}{$\begin{array}{l}\text { Converter } \\
\text { compreensão em } \\
\text { exigências }\end{array}$} & 4 & $\begin{array}{l}\text { Transformar declarações em exigências do cliente. Basear-se } \\
\text { no que se compreende, converter afirmações dúbias das } \\
\text { necessidades do cliente em afirmações precisas sobre suas } \\
\text { exigências. }\end{array}$ \\
\hline & & 5 & Selecionar as exigências mais relevantes. \\
\hline & & 6 & $\begin{array}{l}\text { Organizar as exigências mais importantes, pois você pode, } \\
\text { dessa forma, ver possíveis relações entre elas. }\end{array}$ \\
\hline \multirow[t]{3}{*}{3} & \multirow{3}{*}{$\begin{array}{l}\text { Definir } \\
\text { operacionalmente } \\
\text { exigências para o } \\
\text { desenvolvimento ao } \\
\text { longo da linha de } \\
\text { serviço. }\end{array}$} & 7 & $\begin{array}{l}\text { Solicitar aos clientes que o ajudem a classificar e priorizar as } \\
\text { exigências mais importantes. }\end{array}$ \\
\hline & & 8 & $\begin{array}{l}\text { Produzir medidas para as exigências do cliente. Considerar } \\
\text { possíveis medidas quantitativas e planos de avaliação que } \\
\text { possam ser usados com o objetivo de definir se o serviço } \\
\text { oferecido satisfaz as exigências do cliente. }\end{array}$ \\
\hline & & 9 & $\begin{array}{l}\text { Unificar o conhecimento sobre as exigências do cliente. } \\
\text { Selecionar as medidas que melhor vão avaliar a satisfação do } \\
\text { cliente em relação às suas exigências, selecionar os alvos } \\
\text { adequados dessas medidas, baseando-se no dados do cliente } \\
\text { e nos dados do serviço competitivo. e registrar o aprendizado } \\
\text { para o uso ao longo do fluxo de serviço. }\end{array}$ \\
\hline
\end{tabular}

De acordo com Cheng, a operacionalização do QD (QFD amplo $=\mathrm{QD}+\mathrm{QFDr}$ ) é formada por dois blocos. O primeiro bloco é formado pelo estabelecimento das metas de um determinado produto que foi criado pelo planejamento estratégico da empresa, por pessoas habilitadas gerencialmente e com conhecimentos técnicos sobre o produto. Já o segundo bloco é constituído por desdobramentos sucessivos; para a utilização de matrizes, tabelas, e modelos conceituais conhecidos por unidades básicas de trabalho (UBTs). Portanto, a partir das tabelas tem-se o início do processo de extração de informação do QFD. A matriz, por sua vez, é formada por duas tabelas quaisquer e tem como objetivo formalizar as relações entre elas. Essas relações podem ser do tipo qualitativo, quantitativo e de intensidade (figura 17). Portanto, têm-se as seguintes informações a respeito do tipo de relação (tabela 3) [Cheng et al, 1995]: 
Tabela 3 - Relação e Processo numa matriz

\begin{tabular}{ll}
\hline Tipo de relação & Tipo de processo \\
\hline Qualitativo & Extração - quando é obtida de uma tabela a partir da outra. \\
\hline Quantitativa & Conversão - quando transmite a importância dos elementos de \\
& $\begin{array}{l}\text { uma tabela para outros elementos de outra tabela. O grau ou } \\
\text { intensidade é indicado por símbolos, denominados como Forte, }\end{array}$ \\
& Fraca e Possível. \\
\hline Intensidade & $\begin{array}{l}\text { Correlação - visa identificar as relações entre os elementos } \\
\text { desdobrados do último nível das tabelas. }\end{array}$ \\
\hline
\end{tabular}

A matriz mais conhecida é a Matriz da Qualidade (figura 18), formada pela tabela de desdobramento da qualidade exigida e pela tabela de desdobramento das características da qualidade. Seu uso não pode ser generalizado, pois, em alguns casos não é apropriado.

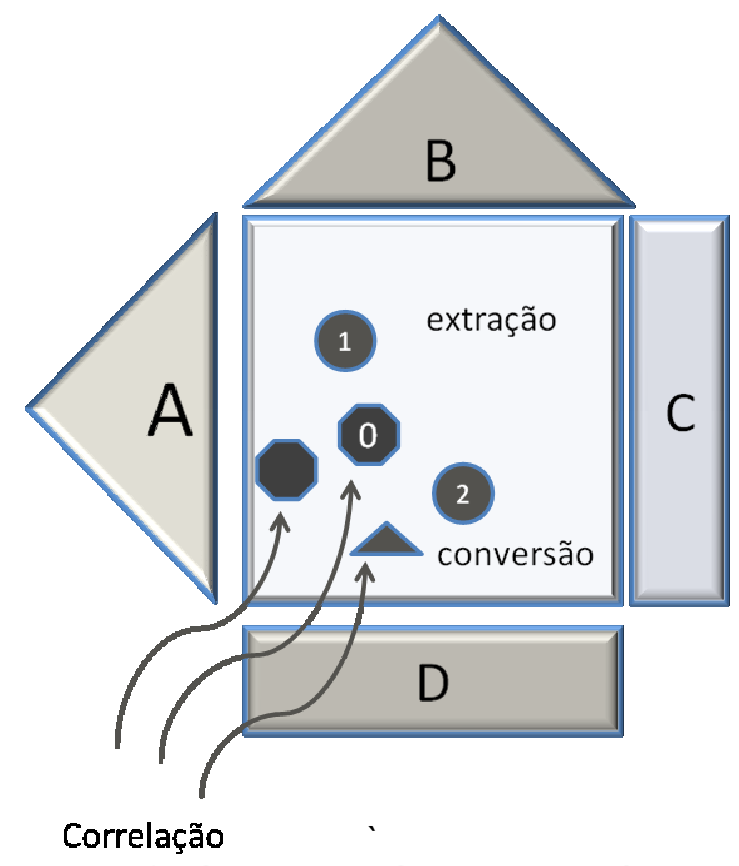

Figura 17 - Representação de uma matriz com seus elementos constituintes Fonte: Cheng et al. 1995. 


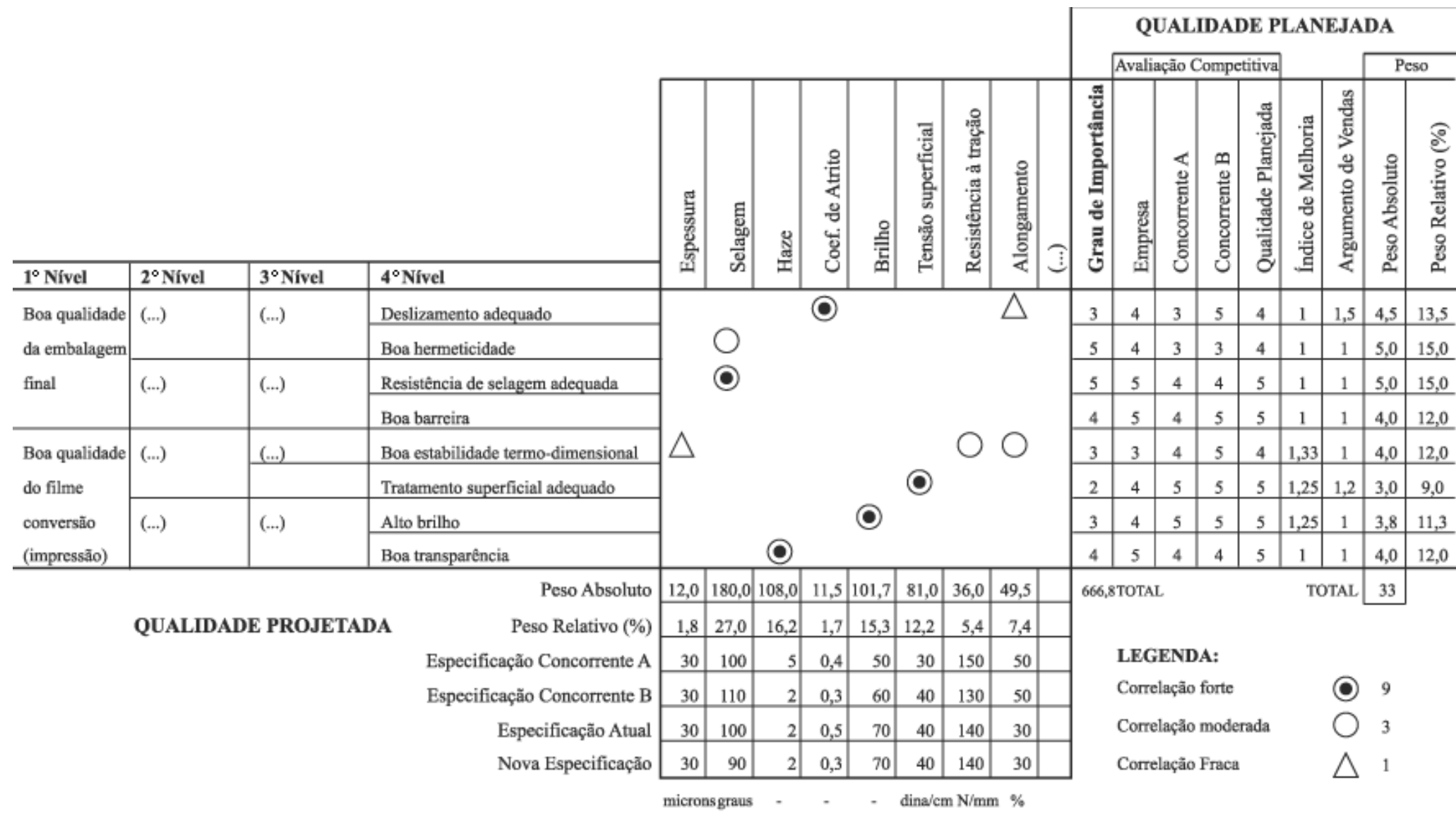

Figura 18 - Exemplo de uma matriz da qualidade

Formado por um conjunto de tabelas e matrizes, o modelo conceitual (figura 19) completo é formado por quatro dimensões: desdobramento da qualidade, da tecnologia, do custo e da confiabilidade. Para alguns autores, o QFD começa como uma forma de mapa conceitual, conforme Cheng esse mapa é dividido em 6 partes ou quartos, a saber, figura 20 [Eureka, 1993; Guinta, 1993; Cheng,1995].

\section{1) Requisitos do Cliente "O que"}

Primeira parte da "Casa da Qualidade" é a mais importante.

Levantam-se os requisitos do consumidor, transformando-os em requisitos técnicos. Dependendo do grupo alvo, os requerimentos (ou requisitos?) podem ser classificados numa escala de 1 (não muito importante) para 5 (muito importante). É feita através de pesquisa em campo, em que o consumidor/cliente é encorajado a descrever suas necessidades e problemas. 


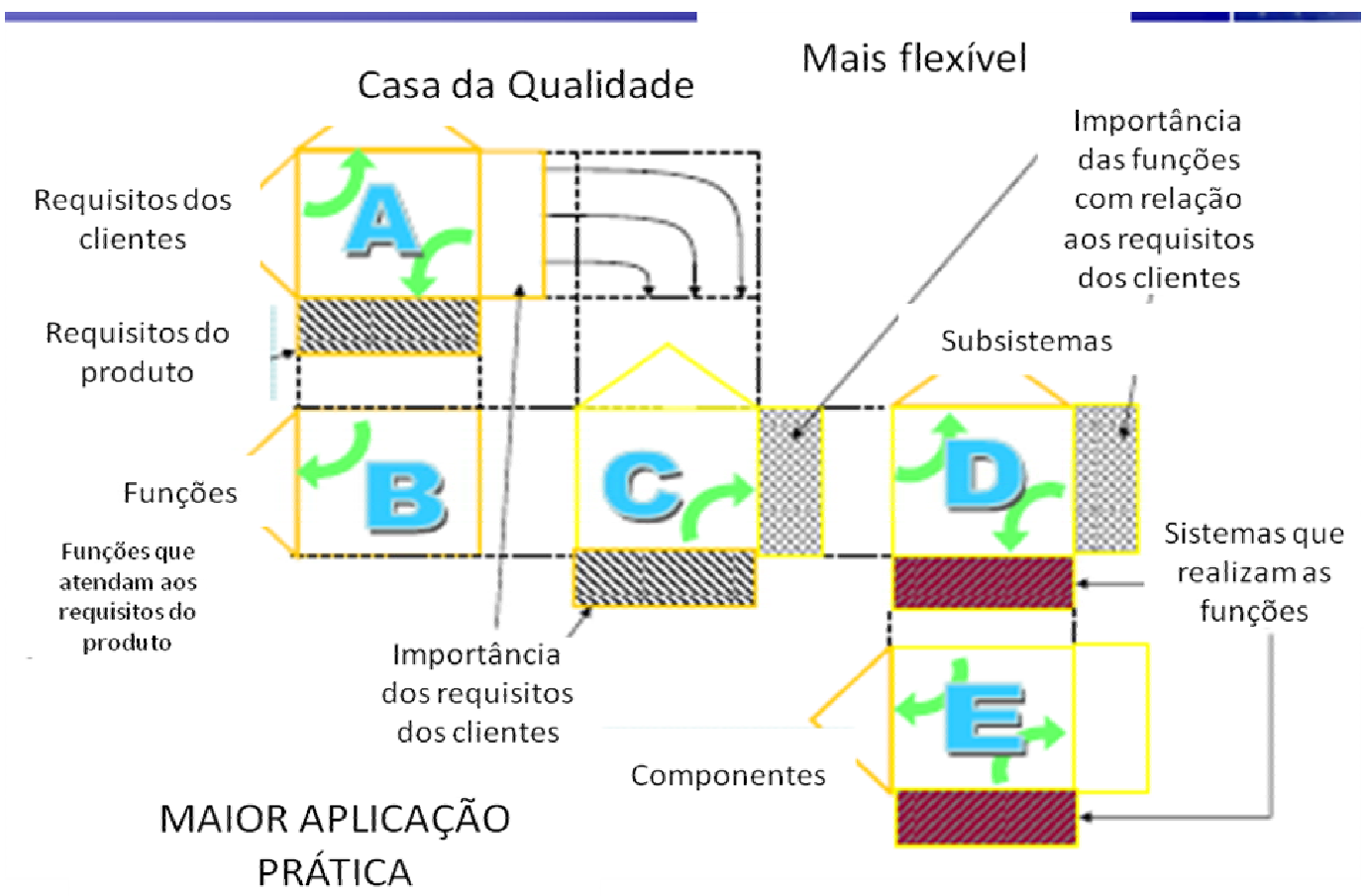

Figura 19- Modelo conceitual para definir matrizes

FONTE: CHENG, Ling Chih. QFD Planejamento da Qualidade. Ed. Littera Maciel, 1995.

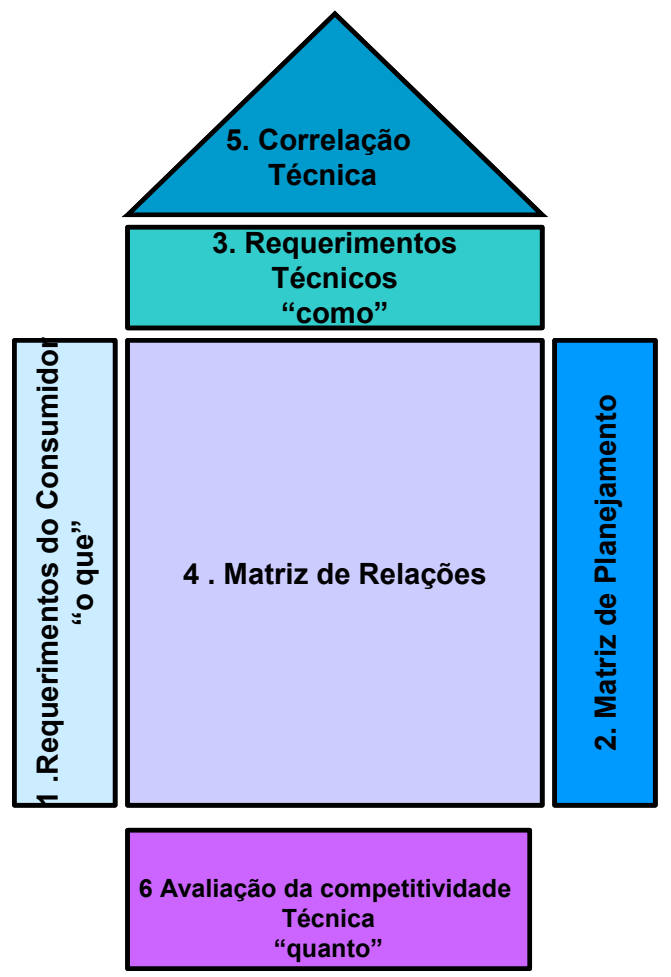

Figura 20 - Casa da Qualidade

\section{2) Matriz de Planejamento}


- Quantificam-se as prioridades dos requisitos do consumidor e sua percepção a respeito do produto.

Levanta-se a importância de cada requisito.

Um outro questionário é feito para medir a importância de cada item.

\section{3) Requerimentos Técnicos "Como"}

- Como atender os requisitos do cliente.

- Nessa matriz define-se a força do relacionamento entre os "O Que" e os "Como",(figura 21) através do uso dos seguintes símbolos: $\odot$ forte, médio 0 , fraco $\square$ e nenhum.

\section{4) Matriz das relações}

Quando existe uma relação entre um como e um quê, o como satisfará determinado requisito do cliente ou resolverá determinado problema.

\section{5) Correlação Técnica}

Mostra relações positivas e negativas entre os itens da lista "comos".

O telhado indica ainda onde pode haver necessidade de esforços adicionais de pesquisa e desenvolvimento.

\section{6) Avaliação da competitividade técnica "quanto"}

Prioridades Técnicas;

- Ponto de Referência competitivo;

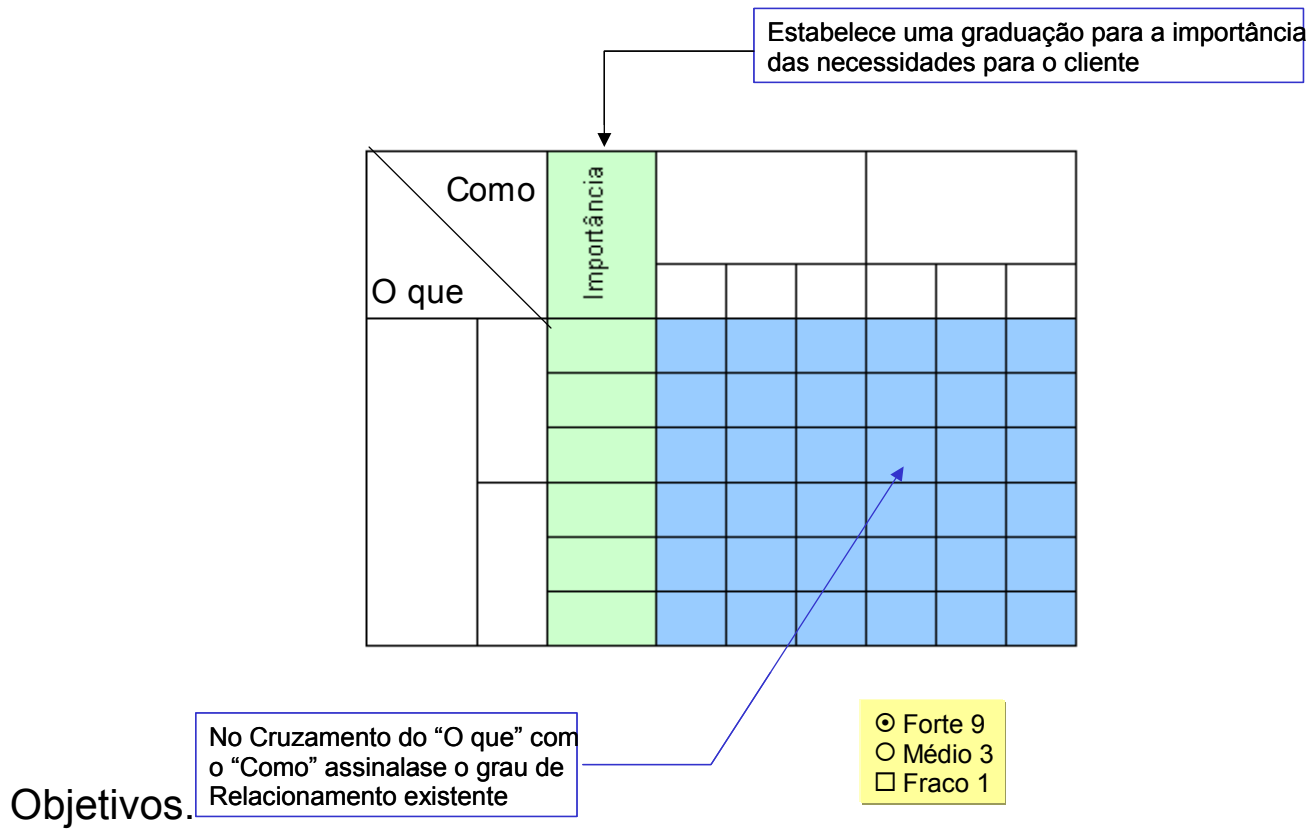




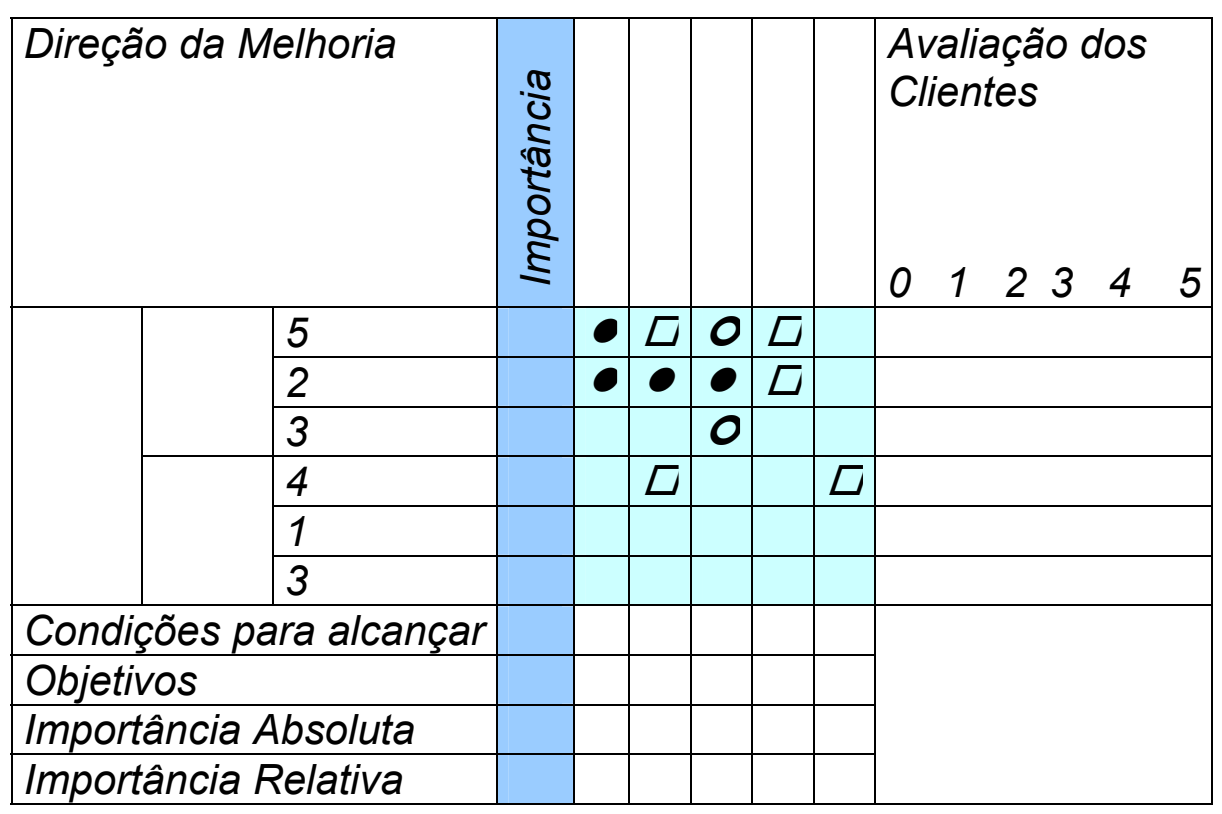

Figura 21 - Matriz - "O que" X "Como"

O QFD é visto por alguns especialistas como uma das ferramentas da qualidade, mas o QFD é mais do que isso, é uma ferramenta de planejamento para desenvolvimento que contribui para a garantia da qualidade.

Abaixo seguem três problemas a serem encarados no QFD para o desenvolvimento de produtos:

- $\quad$ Compreender o que o cliente deseja ver e usar no produto;

- Quais são as funções que o produto deve desempenhar e no que ele pode ajudar o usuário;

- Com base nos recursos disponíveis, qual a melhor forma de dispor ao cliente tendo em vista o posicionamento no mercado.

Veja abaixo os objetivos que podem ser atingidos com a aplicação do QFD na empresa:

- melhoria contínua da qualidade;

- $\quad$ aumento da funcionalidade e do valor agregado aos produtos e serviços;

- $\quad$ redução dos custos de projeto e fabricação em até $50 \%$;

- $\quad$ redução do tempo de desenvolvimento em média de 30\%;

- $\quad$ melhor qualidade através de uma melhor compreensão das necessidades do cliente;

- $\quad$ concepção mais orientada para o cliente; 
- melhoria organizacional nos projetos de desenvolvimento e maior transparência do processo de concepção e desenvolvimento;

- redução dos problemas de fabricação [Eureka,1993] [Guinta 1993] [Cheng, 1995] [Terninko].

O QFD é visto por alguns especialistas como uma das ferramentas da qualidade, mas o QFD é mais do que isso, é uma ferramenta de planejamento para desenvolvimento que contribui para a garantia da qualidade.

O estudo sobre o QFD deixou claro que seria necessária a seguinte estrutura para a implementação:

- Para aplicar o QFD é preciso ter uma equipe de 4 a 7 pessoas, pois menos de 4 pessoas pode trazer atraso para o projeto e mais de 7 pessoas pode causar discussão;

- É necessário ter reuniões semanais com a equipe;

- As equipes de QFD, geralmente, envolvem pessoas da área de Produção, Engenharia de Processo e Engenharia de Produto;

- De acordo com Cheng, o treinamento para se obter um conhecimento básico sobre QFD é de seis horas para as pessoas envolvidas no processo;

- É preciso ter experiência em QFD;

- Não pode haver falta de comprometimento com os membros do grupo;

- É preciso ter suporte gerencial;

- É necessário recurso financeiro e tempo para conduzir a consulta aos clientes;

- $\quad$ Além disso pesquisas mostraram os benefícios do QFD, como ilustra a figura 22 abaixo: 


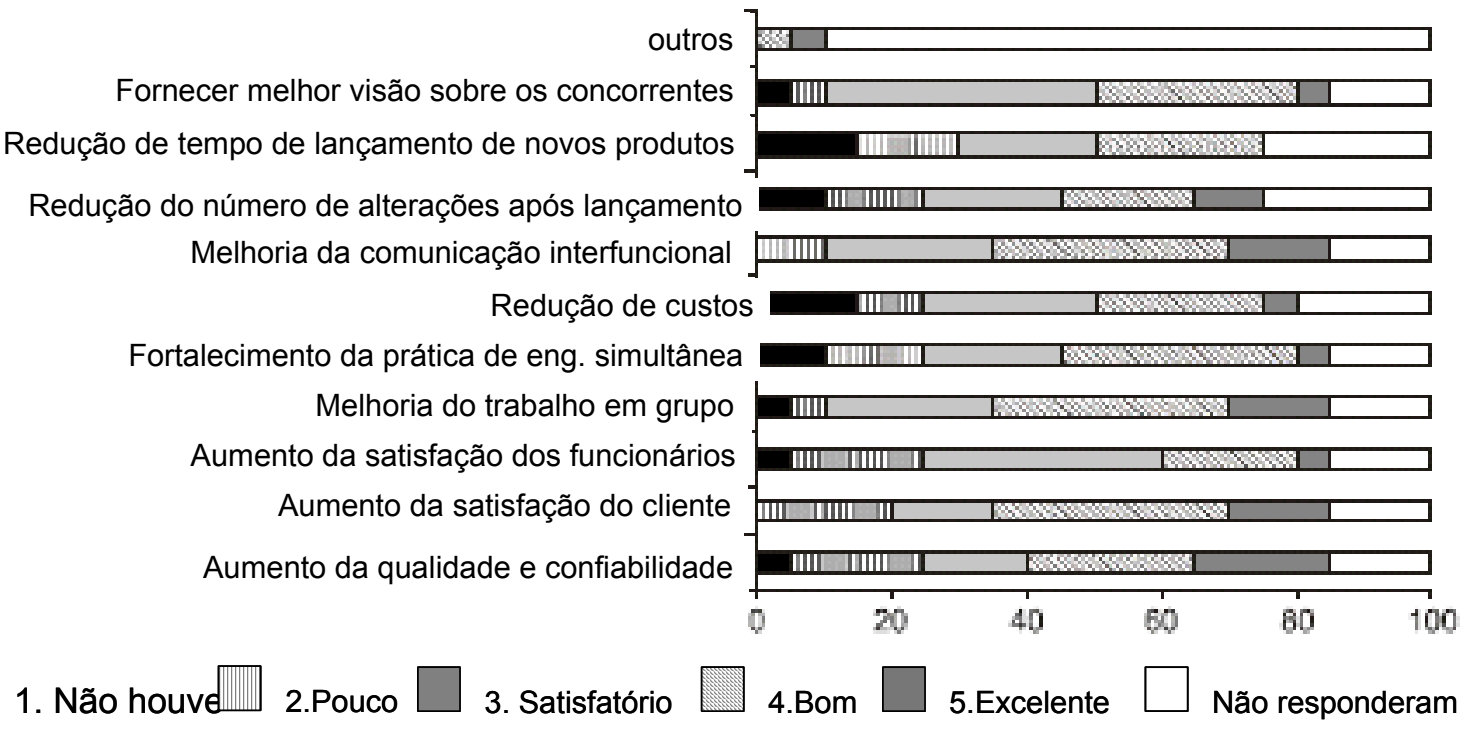

Figura 22 - Benefícios da implantação do QFD ${ }^{2}$

Fonte: Carnevalli , Jose Antonio; Sassi, Andreza Celi; Miguel, Paula A. Cauchick.

De acordo com pesquisas, os benefícios (figura acima) que mais se destacaram com o uso do QFD foram o "aumento da satisfação do cliente", "melhoria da comunicação interfuncional", melhoria do trabalho em grupo" e o "aumento da qualidade e confiabilidade".

\footnotetext{
${ }^{2}$ Aplicação do QFD no desenvolvimento de Produtos: levantamento sobre seu uso e perspectivas para pesquisas futuras.
} 


\section{AMBIENTES CONVERGENTES HETEROGÊNEOS}

Estudos relacionados em análise prospectiva revelam que se vive hoje uma etapa de transformação da sociedade industrial em uma sociedade pós-industrial, tecnotrônica, informacional, sobre dois eixos fundamentais e estritamente relacionados: as novas comunicações integradas, multimídias e interativas, e a engenharia do conhecimento.

Para diversos observadores e teóricos, hoje se presenciam a chamada revolução informacional [Rosnay -1998]; [Lojkine 1999], que, partindo da retroalimentação e da sinergia de uma série de tecnologia, constituíram o que Castells chama de Era da Informação e do Conhecimento [Castells 1999].

O fenômeno tecnológico surge no bojo de uma sociedade que exigirá estudos sobre os novos meios e suas implicações políticas e sociais além do posicionamento que devem ter públicos e profissionais da comunicação, uma vez que a convergência lida com o que há de mais preciso: a informação. De acordo com Sabatinni, a TV interativa é uma tecnologia que integra o acesso à Internet e a recepção de canais de vídeo, uma Internet/TV/Telefone ou Internet e TV a cabo, no mesmo aparelho, o que permite, inclusive, no segundo caso, dispensar a linha telefônica [Sabatine 2000].

No cerne deste advento tecnológico, surgiram questionamentos, como, por exemplo, como será o comportamento das pessoas em face da televisão interativa, quando já habituadas à passividade ou a pseudo-interação da televisão atual.Como deve proceder a sociedade ante as implicações políticas, culturais e sociais dos novos meios e como a comunicação deve adequar sua produção para a convergência tecnológica tendo em vista que uma mesma mensagem deve satisfazer diferentes características dos meios convergentes entre os quais alguns são passivos, outros reativos e outros interativos.

Com base nesses estudos, investigou-se, neste trabalho, quais os serviços interessariam aos consumidores, de que maneira tais serviços seriam atrativos? Para isso, entretanto, foi necessário realizar um estudo a respeito de ambientes convergentes para fazer a integração do consumidor com o meio. Portanto, esse capítulo dedica-se a explanar, de maneira sucinta, o que é convergência e sua infra- 
estrutura para que mais adiante a explanação a respeito da avaliação em ambientes convergentes heterogêneos fique mais clara.

\subsection{Ambientes Convergentes}

Para diversos observadores e teóricos, entre eles Rosnaye Lojkine, hoje se presencia a chamada revolução informacional, que, partindo da retroalimentação e da sinergia de uma série de tecnologias, foi construído o que Castells chama de Era da Informação e do Conhecimento[Rosnay, 1998] [Lojkine, 1999], [Castells, 1999]. A convergência de meios traz novos desafios exatamente quando a informação, principal produto da sociedade do conhecimento, passa a ter maior facilidade de transitar e menor possibilidade de controle. De acordo com Sabatinni, a TV interativa é uma tecnologia que integra o acesso à Internet e a recepção de canais de vídeo, algo como uma Internet/TV/Telefone ou Internet e TV a cabo, no mesmo aparelho, o que permite, inclusive em alguns casos dispensar a linha telefônica, interferindo também e, talvez principalmente, nos modelos de negócio vigentes e que envolvem grandes somas e poderes [Sabatinni, 2000].

No cerne deste advento tecnológico, surgiram questionamentos, como, por exemplo:

- Como será o comportamento das pessoas usando a televisão interativa, quando já foram habituadas à passividade ou a pseudo-interação da televisão atual.

- Como deve proceder a sociedade ante as implicações políticas, culturais e sociais dos novos meios?

- Como a comunicação deve adequar sua produção para a convergência tecnológica tendo em vista que uma mesma mensagem deve satisfazer diferentes características dos diferentes meios?

- Quem e como se controla o negócio?

A convergência dos serviços entre tecnologias heterogêneas implica no conceito de interoperabilidade, ou seja, a capacidade de atuação cooperada entre componentes ou sistemas diferentes, trocando dados e serviços entre si, segundo padrões definidos e praticados pelo mercado. Para que diferentes tecnologias possam implementar esse conceito, precisam utilizar em algum nível sistemas abertos. 
De acordo com Martucci, a Convergência dos equipamentos de comunicação é a forma como são utilizadas as tecnologias, ou equipamentos, para permitir o acesso a vários tipos de serviços e dados. Enquanto a convergência dos fluxos de dados é a forma como são utilizadas as várias interconexões entre redes heterogêneas, para possibilitar um determinado fluxo de dados ou serviço [Martucci, 2005].

Um ambiente heterogêneo, como tratado neste trabalho, é normalmente formado por diversas redes de comunicação interligadas e trocando informações e serviços, os chamados serviços convergentes. Internet, telefonia móvel e transmissão de televisão são exemplos dessas redes.

Conforme Maia quando se considera um ambiente heterogêneo, é claro que todas as redes têm seu recurso próprio de controle para entregar ao usuário qualquer tipo de serviço solicitado, mas esse mecanismo de controle pode ser incompatível entre elas [Maia et al ,2005].

Os sistemas de comunicações móveis, de acordo com Deora, estão sujeitos a grandes variações no sinal de transmissão devido às características intrínsecas desse tipo de tecnologia; portanto, para atender às expectativas de qualidade do usuário é necessário monitorar e medir as diferentes formas de percepção da qualidade acerca de determinado serviço [Deora, 2003].

Surge a necessidade, então, de se adotar, como mecanismo de controle do ambiente heterogêneo, um sistema de Gerenciamento da Rede - GR. Sua finalidade é receber informações sobre a Qualidade dos Serviços na rede, através de sondas implantadas nas diversas sub-redes e equipamentos que compõem a rede heterogênea. O GR dá um tratamento estatístico aos dados capturados e, com isso, elabora um modelo comportamental da rede. A partir dessas informações, é possível, através de outros módulos gerenciadores, atuar sobre os recursos da rede para garantir a Qualidade dos Serviços [Maia,2005].

Deodora propõe que a qualidade dos serviços prestados deve corresponder a, pelo menos, três tipos de expectativas dos usuários:

- Qualidade na Funcionalidade: a qualidade que está relacionada à quantidade de funcionalidades que um serviço pode oferecer;

- Qualidade na Conformidade: a qualidade que está associada à aderência às especificações técnicas;

- Qualidade na Reputação: a qualidade que está associada à percepção que os usuários desenvolvem sobre um determinado serviço associado a outro serviço, 
ou provedor de conteúdo, já existente e conhecido ou, ainda, a uma companhia com uma marca forte no mercado Deora et al,2003]

usuário de tais recursos não se vê mais preso a um local físico de trabalho ou de lazer e tem necessidade, ou vontade, de recorrer às facilidades tecnológicas independentemente do local e do horário em que se encontra e, também, durante seus deslocamentos. Trata-se da Mobilidade generalizada, ou simplesmente mobilidade, que significa a capacidade do uso de diferentes tecnologias de acesso, desprezadas as diferentes localizações, enquanto o usuário se movimenta por si só, permitindo a esse usuário comunicação, uso e gerenciamento consistente de sua aplicação ou serviço através das fronteiras das redes existentes. Mobilidade inclui a capacidade de usar uma determinada aplicação, ou serviço, sem a interrupção de sua atividade, através de várias tecnologias, permitindo o movimento entre pontos de acesso com ou sem fio [ITU, 2004].

A gama de terminais para acesso às redes de comunicação é muito variada. Os mais comuns, no Brasil, são os telefones celulares, os notebooks e os PDAs. A tendência do mercado de tecnologia é a de unificar os serviços em um único terminal, o que passa a exigir uma maior convergência das tecnologias nele aplicadas.

A introdução de novos serviços impõe novos e sérios desafios para as redes atuais, pois, do ponto de vista técnico, deverão suportar um maior tráfego de dados [Llopis et al., 2001].

Essas demandas só podem ser atendidas através da convergência entre tecnologias heterogêneas, permitindo que o usuário transite entre elas de forma transparente para ele.

\subsection{Infra-estrutura}

Oferecer mobilidade, interatividade e convergência exige uma complexa infraestrutura técnica.

O serviço deve ser entregue, pela utilização de tecnologia apropriada disponível, naquele instante, para aquela posição em que o usuário se encontra [Maia, 2005]. 
Essa infra-estrutura inclui, por exemplo: provedores de conteúdo e de serviços, backbones interconectando as diferentes redes, redes de acesso entre provedores e os backbones (através de diferentes meios de comunicação), redes de acesso entre os backbones e as redes de telefonia fixa e celular, redes de TV, redes Wi-Fi, redes ADSL, etc.. A figura abaixo ilustra, esquematicamente, essa infra-estrutura:

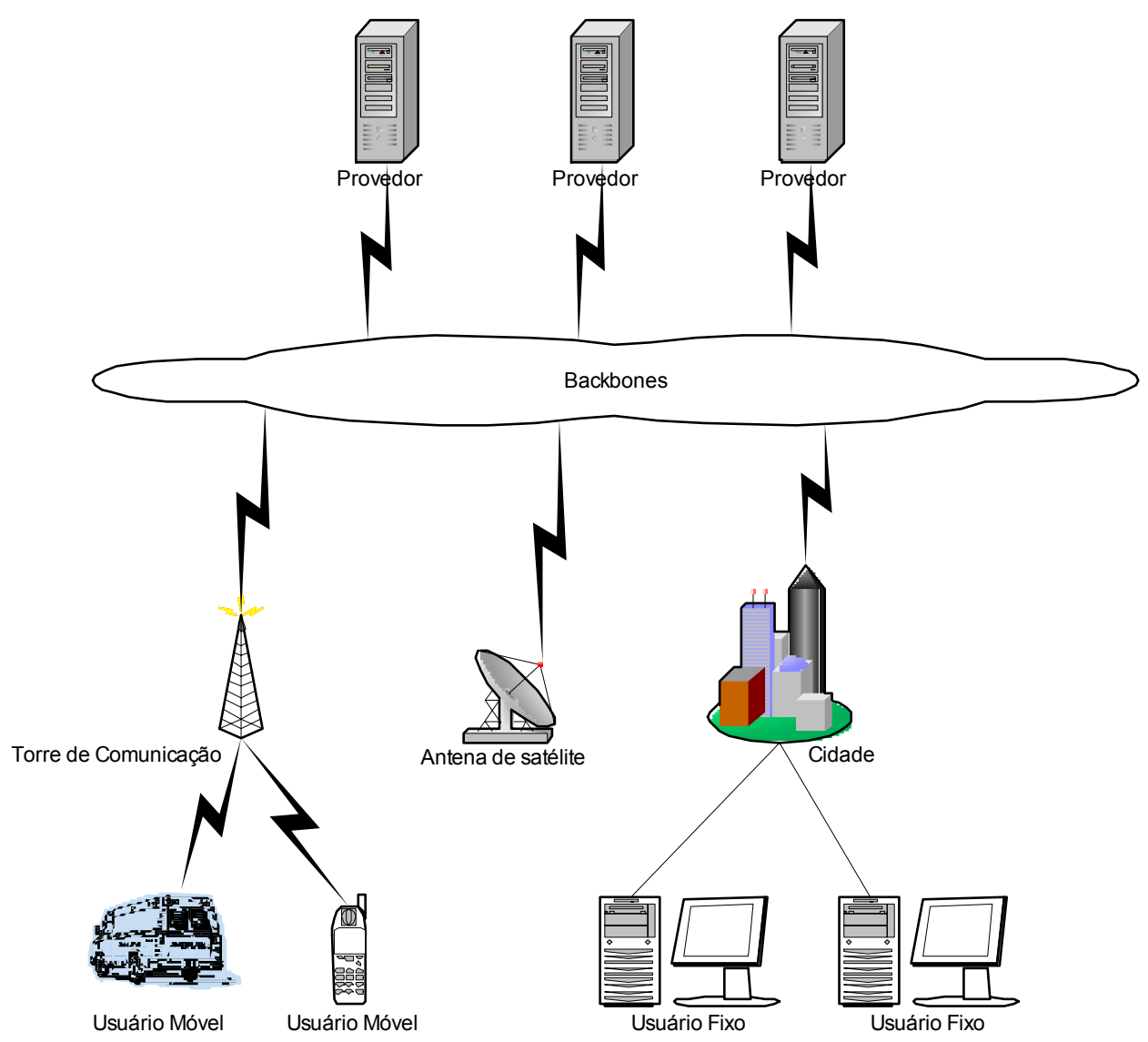

Figura 23 - Ambiente convergente

Para que seja possível o suporte à mobilidade, algumas funções são necessárias, como, por exemplo, mecanismos de identificação e autenticação, funções de autorização e controle de acesso, gerenciamento de localização, alocação e gerenciamento do serviço, gerenciamento de suporte ao usuário, gerenciamento do perfil do usuário, acesso a dados do usuário. 


\section{MODELO DE AVALIAÇÃO}

O modelo de avaliação de serviços convergentes em ambientes heterogêneos consiste de três fases como detalhado neste capítulo. Os trabalhos foram baseados parcialmente nas publicações de Navarro que descrevem os projetos que foram financiados pela Comunidade Européia. Nesses projetos houve também a participação da autora. Como contribuição especial, há a proposta de alterações no modelo de forma a tornar seu uso mais adequado para aplicação em grupos maiores ou em comunidades geograficamente distribuídas, diminuindo drasticamente os custos da fase de aplicação em campo [Navarro, 2003].

\subsection{Modelo proposto para a avaliação}

Neste item é proposto o modelo de avaliação de serviços convergentes em ambientes heterogêneos, detalhando o método de utilização até o nível necessário à aplicação real do modelo proposto é composta por três fases relativamente independentes.

\subsubsection{Primeira fase - Construção de cenários}

O cenário a ser construído parte de propostas de serviços a serem testados e que serão avaliados pelos potenciais consumidores. Ferramentas do tipo "power point" ou "flash" podem ser utilizados para gerar imagens explicativas ou simulações de telas ou ainda simulações de navegação de forma a demonstrar o funcionamento dos serviços propostos e os resultados obtidos pelo uso das funções apresentadas na tela. Note-se que esse tipo de cenário pode ser utilizado para demonstrar desde serviços puramente abstratos, quanto para demonstrar o funcionamento de um equipamento complexo cuja prototipação poderia ter custo proibitivo. 
Podem ser utilizados também simuladores ou protótipos implementados especialmente para os testes em campo. A aplicação de mockups é mais adequada para novos produtos pela simplicidade e baixo custo.

Navarro baseou-se nos trabalhos realizados por Carrol sobre as relações interativas do homem com as novas tecnologias, que tiveram como suporte a utilização de cenários simulando uso de nova tecnologia. [Navarro, 2004][Carrol,89,92,94,95,02] . A figura 24 mostra o processo de construção de cenários.

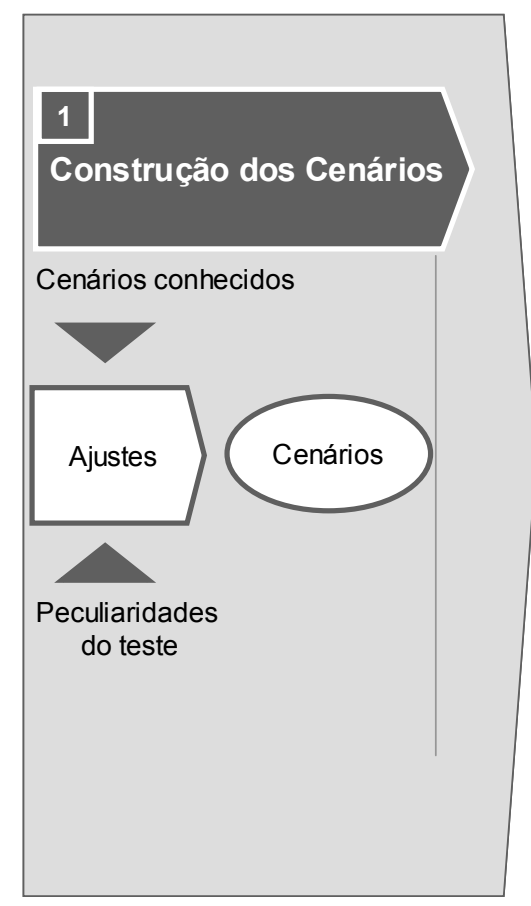

Figura 24 - Processo de Construção de Cenários

\subsubsection{Segunda fase: Seleção das amostras}

Nesta fase são selecionadas as pessoas para aplicação do teste. A figura 25 mostra o processo já dividido nas suas etapas formadoras: Definição dos critérios, seleção do grupo e validação da amostragem. 


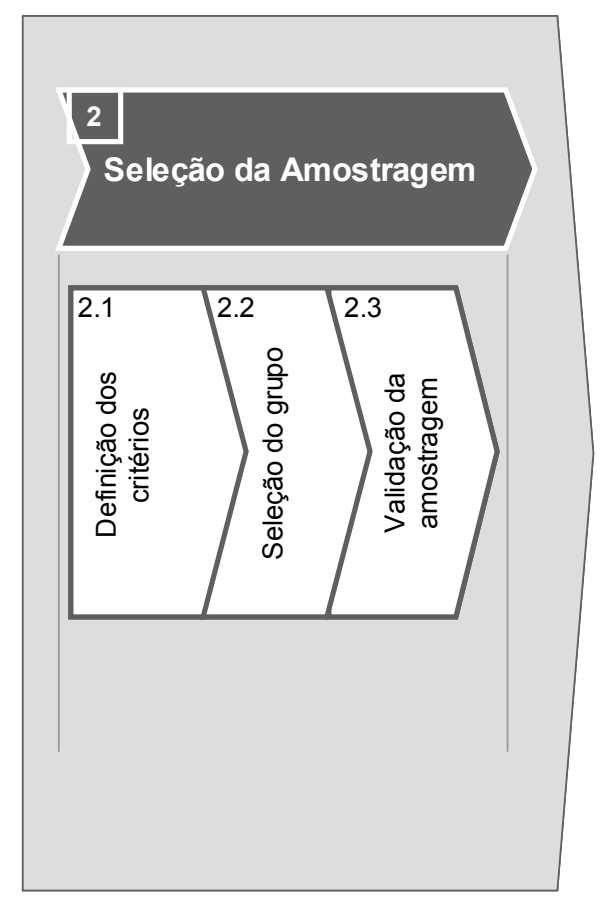

Figura 25 - Seleção da Amostragem

\subsubsection{Definição dos critérios}

Uma população adequada para análise é escolhida tomando-se como base indivíduos pertencentes a grupos com equivalência socio-cultural com os potenciais consumidores dos produtos a serem testados. Dentre os critérios pode-se também escolher faixas etárias, ou quaisquer outras características comuns. Normalmente é mais fácil utilizar algum grupo já formado, com pessoas que se conhecem e pertencentes a uma mesma cultura de consumo.

Funcionários de uma determinada unidade de uma empresa ou estudantes de uma universidade são exemplos dessa categorização.

Os critérios de seleção do grupo a ser estudado devem ser definidos a priori e exprimem as finalidades do teste. A filosofia por trás do teste será também expressa na escolha da amostragem. 


\subsubsection{Seleção do grupo}

A todo o grupo é aplicado um pre-questionário que classifica os indivíduos segundo as necessidades da pesquisa. No anexo A pode-se verificar um exemplo de um préquestionário utilizado em um teste real. Nessa fase é conveniente que o préquestionário seja preenchido sem a identificação clara do elemento do grupo. Essa atitude exclui, tanto quando possível, a escolha de conhecidos ou de pessoas que as demais pessoas do grupo considerem diferentes ou exemplos para todos. A despersonalização da amostra é importante, mas os pré-questionários precisam ser identificados de alguma forma à pessoa no nível da administração do teste através de números de inscrição, por exemplo.

A partir dos resultados do pre-questionário pode-se separar um sub-grupo de pessoas com o perfil desejado. Assim, a escolha dos elementos que efetivamente participarão do teste pode levar a amostra para determinadas características, como, por exemplo, pessoas de uma certa faixa etária ou com um determinado poder aquisitivo. Pessoas que não se enquadrem adequadamente nos critérios que foram previamente definidos deverão ser excluídas da amostra. As especificidades tanto do grupo quanto dos indivíduos que serão avaliados dependem da especificação do teste que se deseja.

No caso do trabalho com serviços convergentes, o pre-questionário avalia as características de uso da tecnologia dos elementos do grupo detalhando como o indivíduo se relaciona com a tecnologia, quanto tempo se expõe a ela, como ela interfere em seu dia a dia.

\subsubsection{Validação da amostragem}

A fase da validação da amostragem, ou validação do teste, deve ser realizada comparando-se os resultados da seleção da amostragem de determinado grupo com as especificações do teste, no caso de um teste único ou com a comparação dos dados médios dos elementos de determinado grupo com os dados médios de outros grupos pesquisados. Isso se torna muito mais importante quando o teste é aplicado 
a grupos de culturas e regiões diferentes. Quando as conclusões forem construídas a partir do teste aplicado, essa comparação também será muito útil para explicar diferenças eventuais nos resultados.

\subsubsection{Terceira fase: Planejamento das atividades em campo e Entrevistas}

É nesta fase que o trabalho em campo necessariamente ocorre. Duas são as etapas principais dessa fase: Desenvolvimento dos questionários e Entrevistas.

A figura 26 mostra o processo dessa fase.

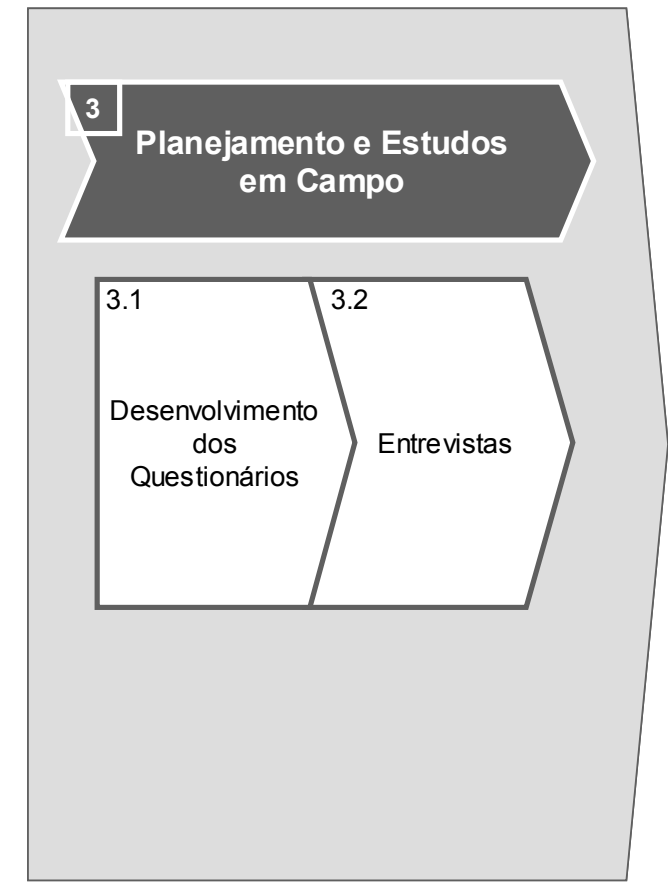

Figura 26- Planejamento e Estudos em Campo

\subsubsection{Desenvolvimento dos Questionários}

Nessa etapa os questionários que serão utilizados em campo são definidos. Esses questionários balizarão o trabalho direto com o grupo. Não são necessariamente 
perguntas que necessitem de respostas diretas do indivíduo que esteja fazendo o teste. São, muito mais, diretrizes de avaliação durante o teste que será executado por um psicólogo ou profissional equivalente e servirá de base para que esse profissional exponha todos os potenciais pontos de dúvida dos avaliados. Esse roteiro deve ser seguido com parcimônia pelo entrevistador, pois a espontaneidade da entrevista não pode ser comprometida pela rigidez do processo. O entrevistado deve ser exposto a problemas e suas reações medidas pelo profissional e anotadas no questionário. As seções de coleta de dados obedecem a um ritual préestabelecido e conhecido apenas pelo entrevistador. É muito importante que o questionário seja elaborado com uma filosofia definida, pois é nele que estará definida a filosofia do teste como um todo.

\subsubsection{Entrevistas}

Neste item são definidas as características das entrevistas. Essas sessões de coleta de dados são realizadas de acordo com a estrutura definida e padronizada.

Sugere-se que o formato seja seguido para evitar diferenças induzidas no teste.

Uma forte sugestão que se tem seguido é que entrevistas desse tipo sejam feitas para duplas. Em duplas as pessoas são mais espontâneas uma vez que um clima de cordialidade seja implantado. As pessoas incitam umas às outras facilitando muito a verificação de diferenças ou semelhanças de opiniões. Essa atitude favorece o clima de conversa e aumenta bastante a quantidade de informações disponíveis para um bom observador. Há muitos dados comportamentais que podem gerar muitas observações. Emoções serão expressas muito além das palavras. Gestos, caras, sorrisos, etc; tudo pode ser observado e atentamente anotado.

Uma seqüência padronizada já testada, como se pode observar nos estudos de casos, é a seguinte:

- Instruções sobre o produto ou serviço: O entrevistador faz uma breve descrição dos produtos ou serviços que se pretende avaliar e explica o procedimento da entrevista; 
- Apresentação dos cenários: O entrevistador apresenta os cenários de forma cronológica e coerente, fazendo o entrevistado seguir caminhos pré-definidos e conhecer os produtos que estão sendo testados. Trata-se de uma demonstração do produto. Nesta etapa não se questionam os entrevistados, apenas são avaliadas suas reações;

- Utilização dos cenários: Os entrevistados são excitados a utilizarem os cenários, navegarem nas telas e experimentarem os produtos através dos mockups ou protótipos. Algumas perguntas são feitas, forçando os entrevistados a procurarem soluções ou respostas, ou simplesmente a formar alguma impressão sobre determinado detalhe. Perguntas sobre suas expectativas em relação aos produtos ilustrados e como aqueles produtos podem ser utilizados no seu dia a dia;

- Aplicação do pós-questionário: É aplicado um pós-questionário a todos os entrevistados, isoladamente e imediatamente após suas entrevistas. Nessa fase o entrevistado precisa expressar suas opiniões e avaliar os produtos propostos a ele, sugerindo coisas, reclamando de coisas que não tenha gostado, e expressando quaisquer outras opiniões que queira como, por exemplo, comparar com produtos que ele julga equivalentes. Um pós-questionário real pode ser avaliado no anexo B. O objetivo desse questionário é complementar as perguntas feitas durante a entrevista. A literatura relata que questionários desse tipo podem fugir da realidade vivida pelos usuários, portanto, as entrevistas tornam-se a maneira mais segura para adquirir esse tipo de informação.

Outras características dos produtos podem ser avaliadas facilmente quando identificadas na filosofia do teste e definidas coerentemente na formulação tanto dos cenários quanto dos questionários. Entrevistas podem ter um cunho puramente técnico, tanto do ponto de vista de design da interface, por exemplo, quanto cunho comercial, do ponto de vista de definição de modelos de negócio ou até mesmo comparativas de preços entre alternativas dadas. Podem ser utilizada em conjunto com outras técnicas, como a do QFD, por exemplo. No caso de avaliação de novos produtos, quando o entrevistado não conhece e não consegue comparar diferentes produtos, a filosofia presente no QFD pode ser implementada através desse formato de entrevistas utilizando-se mockups que demonstram o produto e sua aplicabilidade ao entrevistado. 


\subsubsection{Análise dos resultados}

$\mathrm{Na}$ fase de análise dos resultados serão produzidos os relatórios com todos os resultados do experimento.

Nessa fase também é importante a participação de profissional da área da psicologia para a interpretação correta das expressões e opiniões dos entrevistados.

Os resultados devem incluir toda a documentação utilizada, incluindo-se os questionários respondidos, as anotações durante as entrevistas e os arquivos de áudio e/ou vídeo das entrevistas que possibilitem discussão sobre as conclusões no futuro.

Com base nos modelos e normas estudadas pode-se aprimorar alguns detalhes do processo de entrevistas como, por exemplo: [Navarro,2003].

- Existência de psicólogo durante a entrevista;

- Duração de aproximadamente uma hora e meia cada entrevista;

- Questionário de uso durante a entrevista, que pode ser visto no anexo C;

- Gravação em áudio ou áudio e vídeo das entrevistas, o que possibilita análise posterior além de servir de evidência objetiva da sua realização;

- Realização das entrevistas sempre no idioma dos entrevistados, mesmo quando os resultados devam ser transcritos. Essa transcrição nem sempre é trivial, pois expressões são mais dificilmente interpretadas;

A figura 27 mostra o modelo completo. 


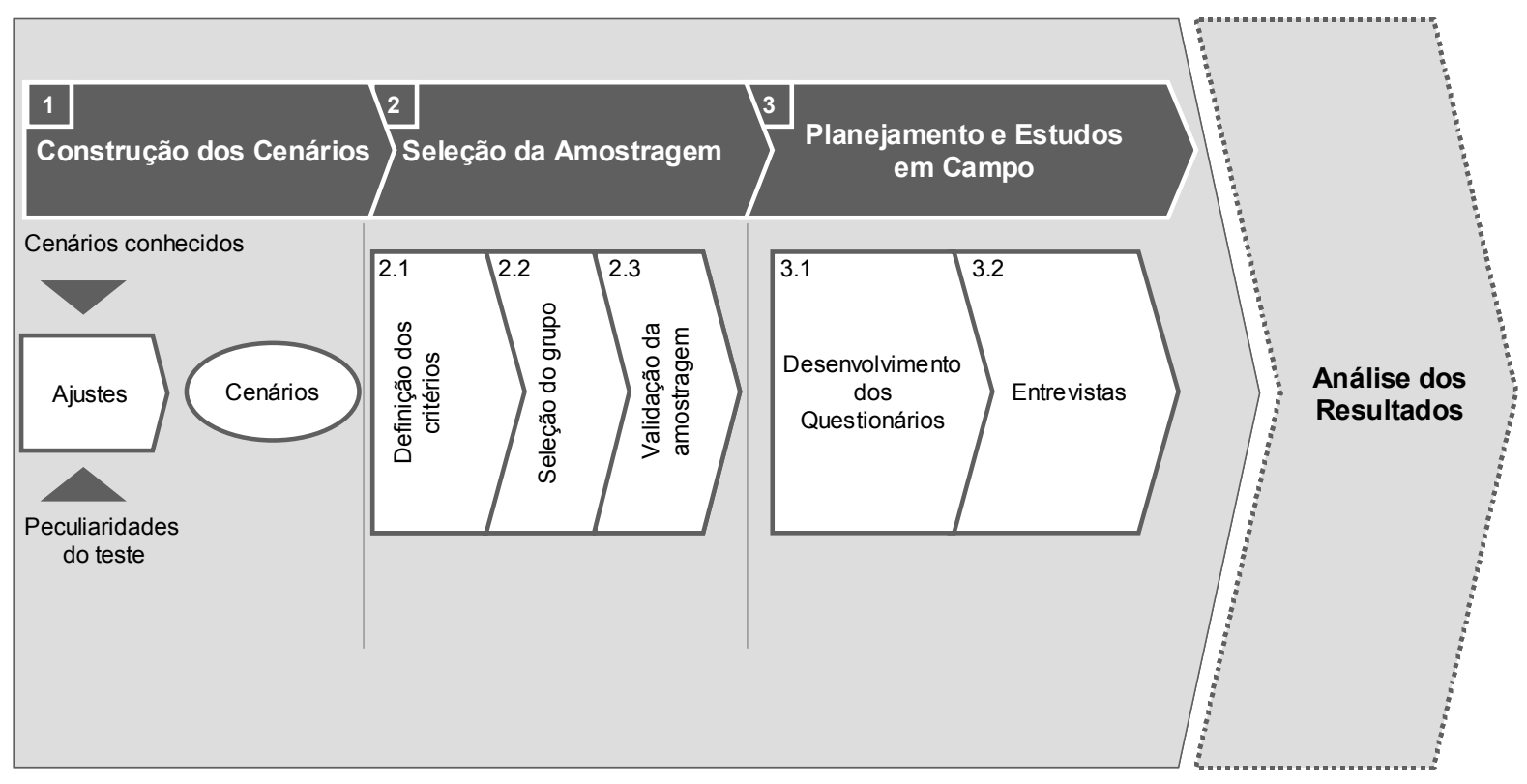

Figura 27 - Modelo completo

\subsection{Modelo WEB}

A principal dificuldade de utilização do modelo como proposto anteriormente é que as entrevistas precisam tomar o tempo necessário para serem efetivas. Cada entrevista demora cerca de duas horas, entre preparação no local e a entrevista propriamente dita. O número de pessoas entrevistadas, em duplas, faz com que o a equipe fique plenamente operante durante todo o tempo para completar o grupo. Equipes cansadas ao final do dia não tem um rendimento adequado à análise dos detalhes e esse trabalho leva alguns dias para cada grupo que se queira avaliar.

Quando os produtos e serviços tendem a ser mundialmente aplicados, com populações de diferentes culturas originais, diferentes poder de compra e diversas bases geográficas, essas entrevistas acabam comprometendo completamente o custo do levantamento desejado.

Dessa forma foi proposto um modelo modificado que mantivesse as boas características do modelo proposto anteriormente, mas que facilitasse o processo de entrevistas. Um modelo aplicado pela WEB.

Esse novo modelo foi proposto bastante calcado na experiência bem sucedida do modelo anterior com as seguintes alterações: 


\subsubsection{Primeira fase: Construção dos Cenários}

$\mathrm{Na}$ construção dos cenários a novidade no novo modelo é a utilização de uma interface web, ou seja, o entrevistado será convidado a navegar por um site devidamente produzido que passa a ser o cenário do produto. Na navegação já será possível colher informações sobre a forma com que o entrevistado encarou cada um dos processos de escolha durante a exposição.

Não há problemas tecnológicos novos na simulação de um produto ou serviço através da navegação pela WEB. A novidade passa a ser a forma de apresentação e de interação. A presença do especialista em fatores humanos, com conhecimento de psicologia deve ser utilizada na elaboração dos cenários.

\subsubsection{Segunda fase: Seleção da amostra}

$\mathrm{Na}$ seleção da amostra, utiliza-se um processo de convites por e-mail a grupos devidamente escolhidos. Nesse convite há a oferta de algum ganho real para que os potenciais entrevistados tenham interesse em participar ativamente do processo. Esse ganho real pode ser um brinde que valha a pena e que pode ir crescendo de importância conforme o entrevistado vai sendo encaminhado pelas próximas etapas da navegação ou do teste como um todo.

Não há qualquer dificuldade em responder o pré-questionário pela WEB. As respostas são facilmente tabuladas, registradas, incluindo-se meta dados, como, por exemplo, tempo utilizado no preenchimento.

Seleção do grupo e validação da amostragem pode facilmente ser feita off line, na base de dados coletada pela interface WEB. Novamente um profissional da área da psicologia é necessário para interpretar resultados. O pré-questionário deve, necessariamente, ser feito com questões de múltipla escolha muito bem elaboradas, pois o processamento fica tremendamente facilitado. 


\subsubsection{Terceira fase: Planejamento das atividades em campo e Entrevistas}

Nessa terceira fase é onde se encontram as maiores diferenças no processo executado pelos dois modelos. A preparação dos questionários e a preparação da apresentação do produto ganham, nessa versão WEB, muita importância, pois não haverá a possibilidade de o psicólogo estimular o entrevistado durante a entrevista como ocorria no caso presencial. Outra importante diferença é a solidão das respostas do entrevistado uma vez que ele responde sozinho e não em duplas, perdendo-se o efeito multiplicador da interferência mútua.

A preparação dos questionários e da apresentação do produto passa a ser o elo de ligação entre o psicólogo e o entrevistado. Devem estar presentes nesses modelos WEB todas as possibilidades para análise posterior das respostas. Nas experiências realizadas, as questões de múltipla escolha, com número definido de alternativas nas respostas, demonstraram ser a melhor opção.

A figura 28 mostra o modelo WEB.

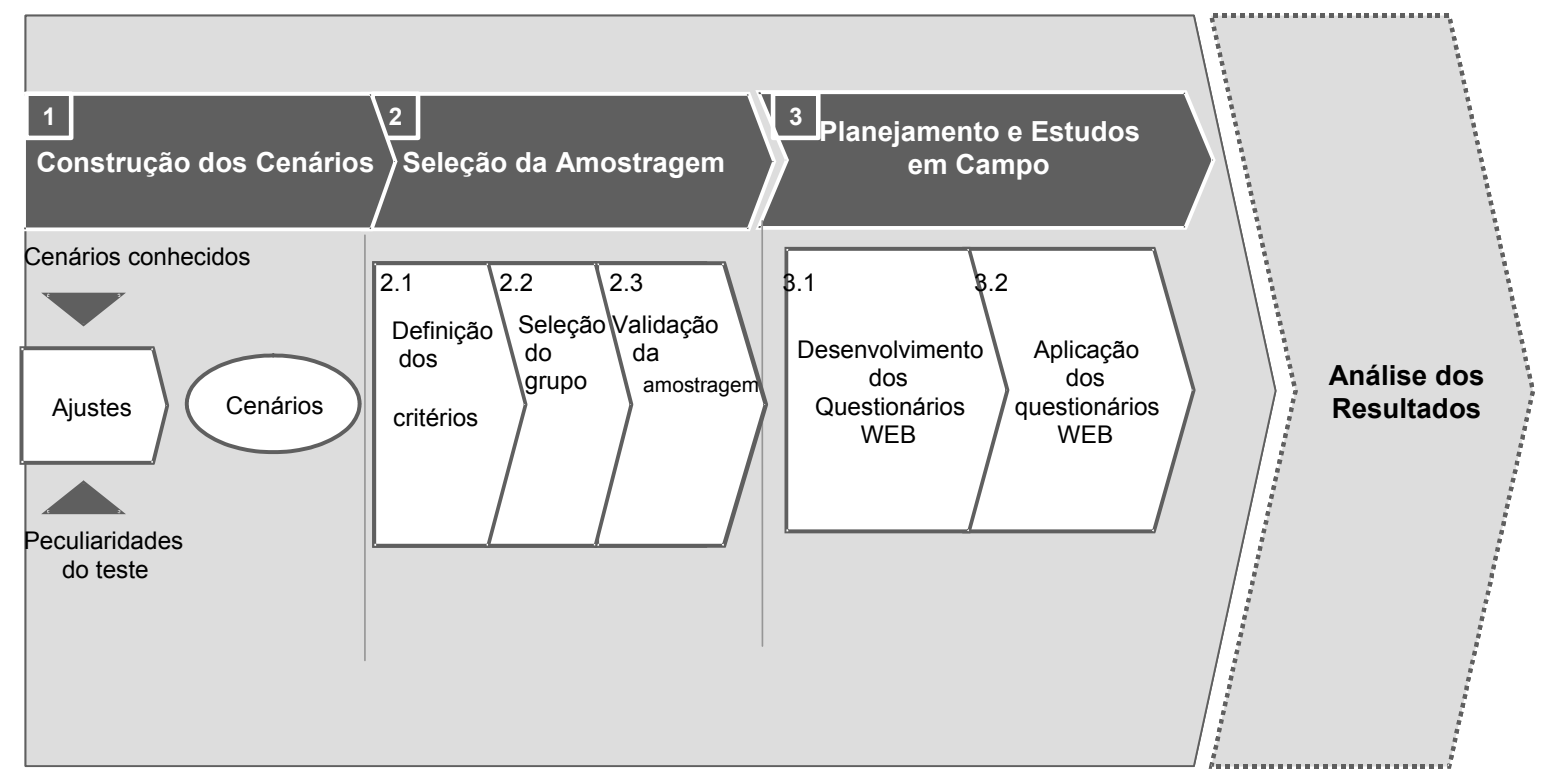

Figura 28 - Modelo WEB

Em resumo, as principais diferenças em relação ao modelo anteriormente proposto podem ser listadas como a seguir: 
a) um pré-questionário com o objetivo de coletar informações que permitam conhecer algumas características dos participantes e traçar o perfil para que se possa selecionar a amostra de interesse, a partir de critérios já estabelecidos;

b) apresentação de uma tela inicial com explicações gerais referentes ao objetivo da pesquisa. A finalidade, nesse momento, é de despertar o interesse do participante em conhecer a proposta e incentivar sua cooperação e fornecimento das instruções básicas necessárias à participação; Muitas vezes, será necessário criar algum interesse específico do entrevistado na forma de brindes ou sorteios;

c) apresentação do cenário para simulação de serviços e interatividade com os usuários [Navarro,2003] Estando o usuário em plena navegação simulada, apresentam-se as questões sobre os serviços [Navarro,2003]. As questões são formuladas com base nos mesmos critérios que as questões preestabelecidas para entrevista presencial semi-estruturada definida para o processo anteriormente utilizado que são adaptadas e reorganizadas para se adequarem ao formato de navegação WEB;

d) a presença de um profissional da área da psicologia que, nesse novo modelo, trabalha na preparação do teste e na avaliação,não mais estando disponível durante a aplicação do teste que passa a acontecer em qualquer horário e sem nenhuma restrição geográfica. 


\section{APLICAÇÃO DO MODELO (ESTUDO DE CASO)}

Esse capítulo tem como objetivo descrever dois estudos de caso que impulsionaram o desenvolvimento do modelo de avaliação de serviços convergentes em ambientes heterogêneos.

A primeira aplicação dos conceitos vistos foi feita no projeto Frevo. Esse projeto teve como objetivo desenvolver um aparelho com o qual usuários de comunidades carentes, alfabetizados ou não, pudessem se comunicar com outros indivíduos enviando e recebendo recados de voz. Os recados de voz são uma grande alternativa para um público que esteja distante da tecnologia e inclui toda uma nova categoria no mundo da comunicação digital: os não alfabetizados.

Um público tão distante da revolução digital impõe novas e importantes restrições aos projetos de inclusão. A usabilidade passa a ser um requisito básico num projeto com tão poucos recursos, quer sejam do dispositivo, que precisa ser barato, quer sejam dos usuários que não podem ler instruções e não tem experiência anterior com aparelhos desse tipo.

A empresa patrocinadora desenvolveu um certo número de protótipos e distribuiu na comunidade carente chamada Chão de Estrelas, em Recife. A participação da equipe da USP se deu na avaliação de aceitabilidade dos serviços pelos os consumidores.

Foram desenvolvidos questionários e foram realizadas visitas à comunidade. Foram desenvolvidas as matrizes do QFD demonstrando como avaliar cada serviço quando comparado com fatores mais conhecidos ou próximos do dia a dia das pessoas que estavam efetivamente experimentando os serviços. Entregues os questionários, o projetonão teve continuidade.

Nesse momento houve uma oportunidade ainda maior. A equipe foi envolvida em um projeto internacional chamado INSTINCT. A experiência é descrita a seguir. 


\subsection{Projeto INSTINCT}

Este item apresenta um estudo de caso importante para o desenvolvimento e validação do modelo proposto. A equipe da USP participou de um projeto internacional chamado INSTINCT - IP-based Networks, Services and Terminals for Converging sysTems - patrocinado pelo IST - Information Society Technology - da Comunidade Européia [INSTINCT,2007].

Uma das missões da equipe da USP estava relacionada com a definição de produtos e serviços que seriam de interesse da população brasileira. Outra equipe brasileira estava com a mesma missão e os relatórios finais seriam confrontados.

Foram criados, durante o projeto, dois cenários europeus e um terceiro cenário brasileiro.

A equipe decidiu utilizar os cenários europeus nos testes em São Paulo pois esses poderiam avaliar serviços direcionados a uma sociedade de consumo mais próximos à sociedade que vive na cidade de São Paulo e que tem hábitos de consumo que incluem os produtos e serviços que eram propostos nos cenários europeus. A outra equipe brasileira iria aplicar o modelo brasileiro em Florianópolis.

As figuras 29 e 30 são amostras dos cenários europeus Helga Schmidt, para o ambiente de TV Digital, e John Doe, para o ambiente de telefonia móvel.

\footnotetext{
${ }^{3}$ Aplicação do QFD no desenvolvimento de Produtos: levantamento sobre seu uso e perspectivas para pesquisas futuras.
} 


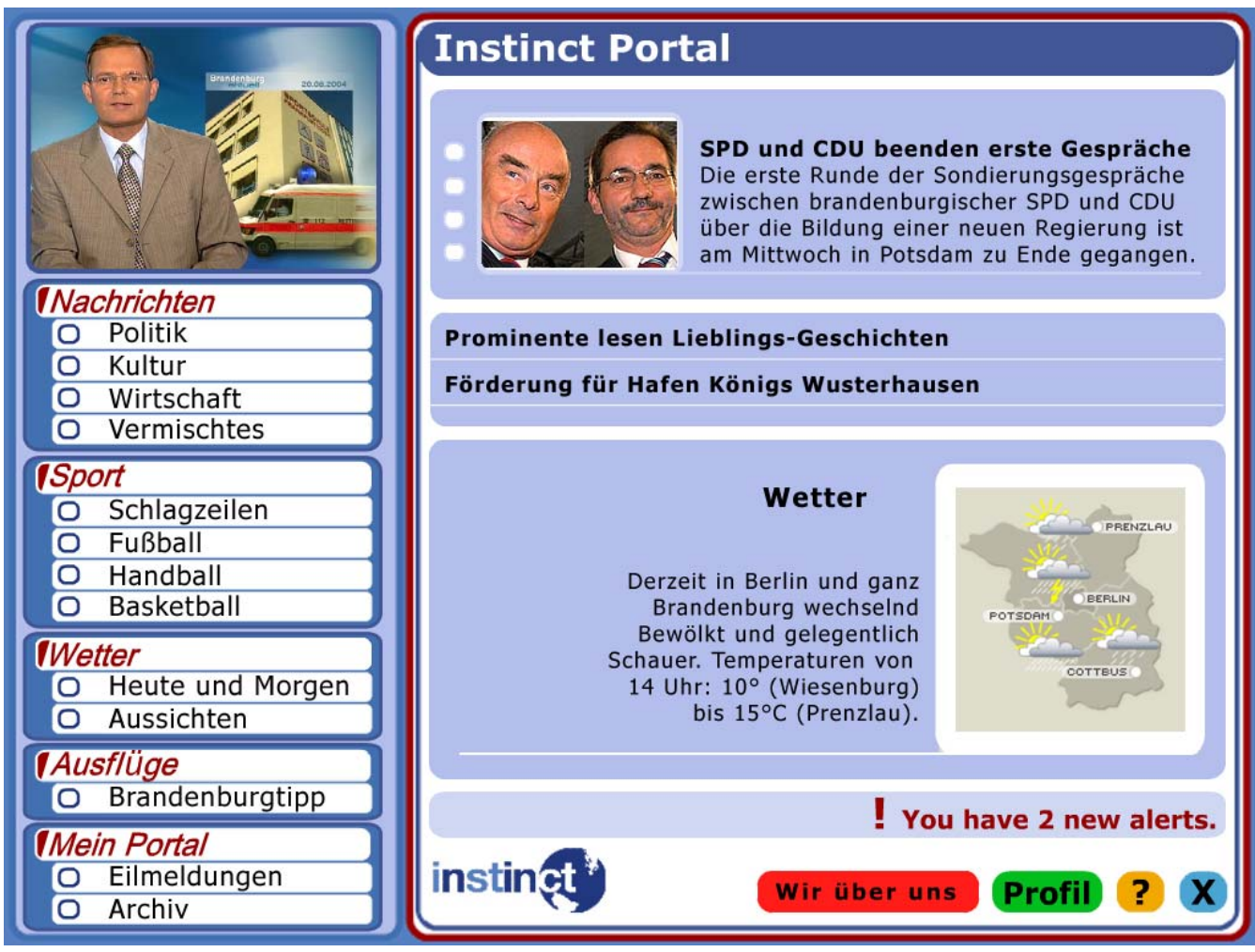

Figura 29 - Cenário Helga Schmidt

Fonte INSTINCT at Villagein IBC 2005 BY John Cosmas, Brunel University

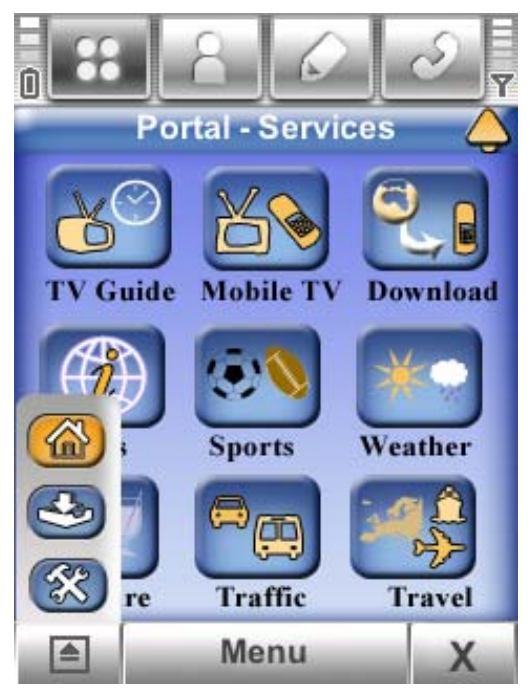

Figura 30 - Cenário John Doe

Fonte: INSTINCT at Villagein IBC 2005 BY John Cosmas, Brunel University

A partir dos cenários europeus, pode-se gerar versões brasileiras de cenários equivalentes, uma localização dos cenários para a realidade brasleira. $\mathrm{O}$ resultado desse no cenário John Doe pode ser avaliado nas figuras 31 e 32 . Uma tela de apresentação do cenário Helga Schmidt adaptado para o Brasil pode ser vista na figura 33. 

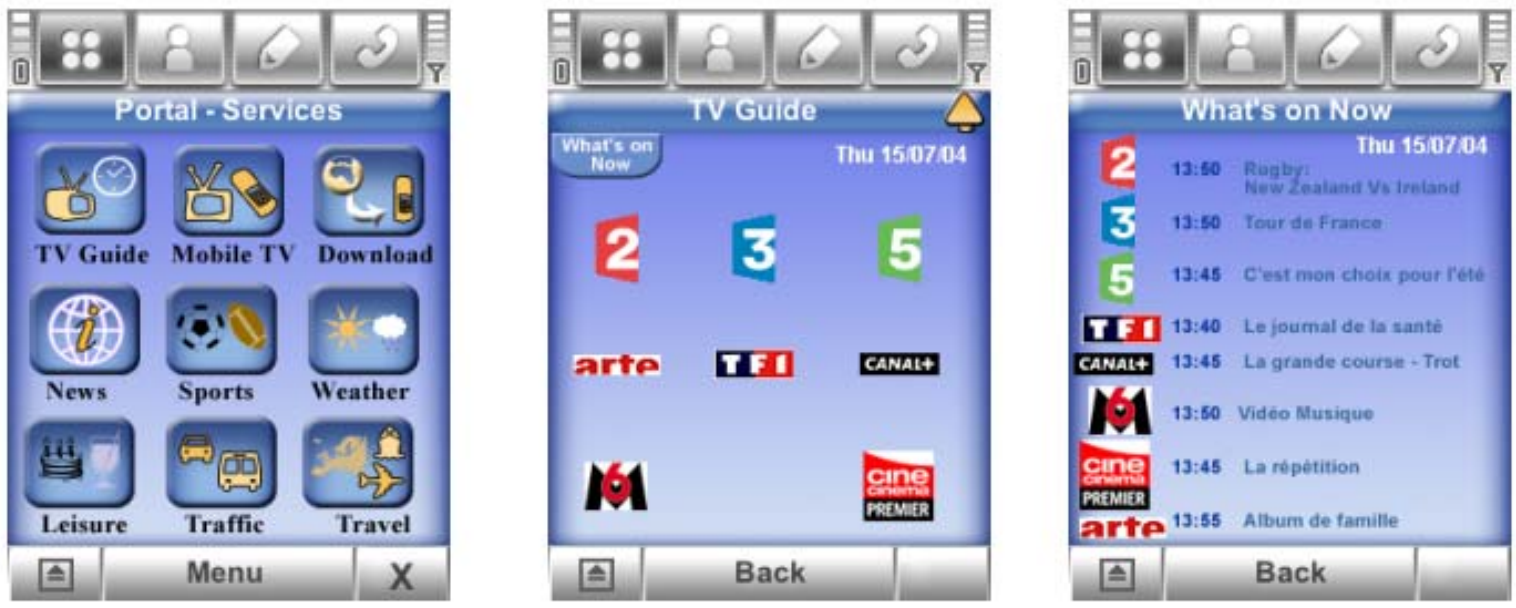

Figura 31 llustração de uma das tarefas do cenário John - original Fonte: Navarro, 2003.
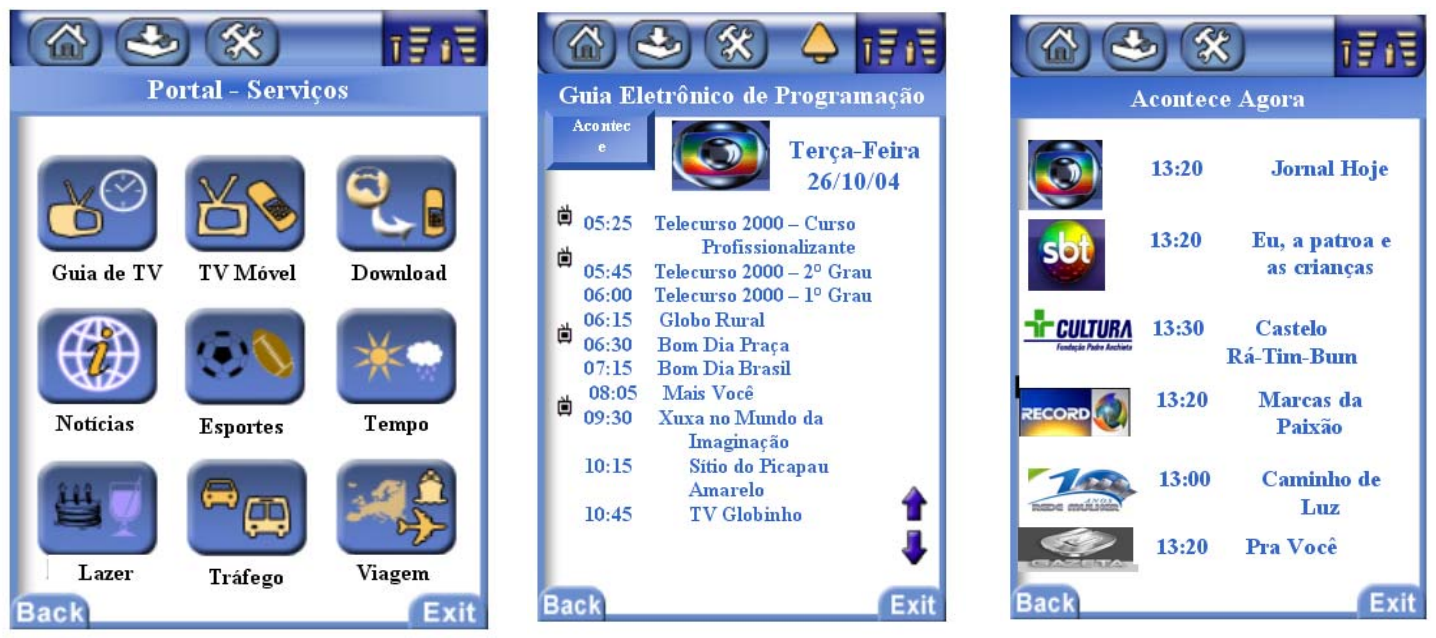

Figura 32-llustração de uma das tarefas do cenário John - adaptado para o contexto brasileiro 


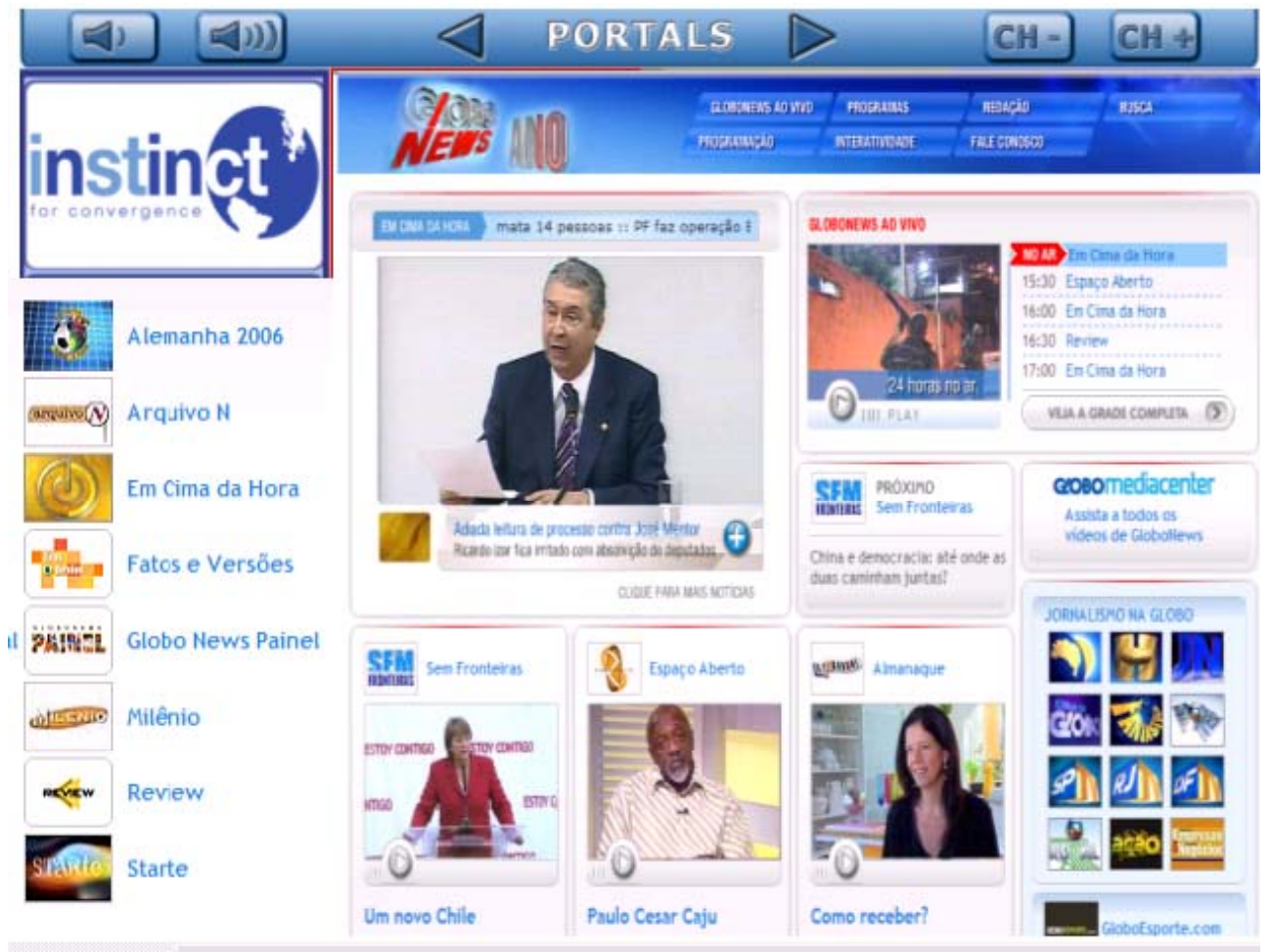

Figura 33 - Cenário Helga Schmidt adaptado para o contexto brasileiro

Conforme Carrol a utilização de cenários vem sendo utilizada como um meio eficaz de descrição dos serviços pois são narrativas textuais sob o ponto de vista do usuário. Por serem representados em linguagem natural, os cenários permitem a exploração de idéias através da interação do desenvolvedor e os usuários, sobre as possíveis situações de uso do sistema ou avaliação de serviços. Em geral, essas narrativas "identificam a pessoa como tendo certas motivações em relação ao sistema, descrevem as ações executadas e algumas razões pelas quais essas ações foram tomadas, e caracterizam os resultados em termos das motivações e expectativas dos usuários". [ Carrol, 1989,1992,1994,1995,1995,2000,2002 ].

\subsubsection{Testes no Brasil}

Considerando que os brasileiros que vivem nos grandes centros urbanos podem ser economicamente comparáveis aos europeus, buscou-se selecionar participantes que se adequassem aos critérios europeus, porém levando em conta a especificidade da realidade e contextos brasileiros. O pré-questionário foi utilizado para a seleção de 
amostras comparáveis com as obtidas com os entrevistados na Espanha e Inglaterra, conforme tabela 4:

Tabela 4 - Descrição dos entrevistados e critério de escolha

\begin{tabular}{|c|c|}
\hline Descrição dos entrevistados & Critério para a escolha dos participantes \\
\hline Jovens, com independência financeira. & $25-40$ anos \\
\hline $\begin{array}{l}\text { Profissionais de áreas administrativas e } \\
\text { técnicas, alunos de cursos de pós- } \\
\text { graduação da Universidade de São Paulo, } \\
\text { engenheiros e consultores de negócios }\end{array}$ & $\begin{array}{l}\text { Fazem uso da tecnologia no trabalho e na vida } \\
\text { pessoal. }\end{array}$ \\
\hline $\begin{array}{l}\text { Passam a maior parte do tempo no } \\
\text { transito: trens, carros aeroportos, etc. }\end{array}$ & Viajar \\
\hline $\begin{array}{l}\text { Têm muita experiência com e-mail, uso da } \\
\text { Web (chat, noticias, clips, downloads de } \\
\text { vídeo entre outros). }\end{array}$ & $\begin{array}{l}\text { Fazem uso do e-mail para negócios e assuntos } \\
\text { pessoais. Todos os dias utilizam o e-mail. Fazem } \\
\text { download de vídeos e software pela Internet pelo } \\
\text { menos } 2 \text { vezes ao mês. }\end{array}$ \\
\hline $\begin{array}{l}\text { Muita experiência no uso de multimídia } \\
\text { (TV, vídeo e sistemas de áudio) }\end{array}$ & $\begin{array}{l}\text { Assistem TV e filmes pelo menos } 2 \text { vezes por } \\
\text { semana. Assistem streaming vídeo e musicas da } \\
\text { Internet pelo menos } 2 \text { vezes ao mês. }\end{array}$ \\
\hline Fazem uso de tecnologia móvel & $\begin{array}{l}\text { Em média faz mais de um ano que utilizam o telefone } \\
\text { móvel.Utilizam PDA entre outras tecnologias como } \\
\text { iPod etc.. }\end{array}$ \\
\hline
\end{tabular}

As entrevistas foram realizadas na cidade de São Paulo com uma amostragem de 20 selecionados, escolhidos a partir de um grupo diversificado que incluiu: profissionais de áreas administrativas e técnicas e alunos de cursos de pósgraduação da Universidade de São Paulo além de engenheiros e consultores de negócios. Em relação ao gênero dos participantes da pesquisa, foi garantida a representatividade de ambos os sexos, sendo que a amostra foi composta por $46 \%$ de participantes do sexo feminino e $54 \%$ do sexo masculino.

Todos os escolhidos são usuários da Internet há mais de dois anos e a utilizam na maior parte do dia, seja a trabalho, seja por motivos pessoais; fazem uso da tecnologia de informação para executar várias tarefas do cotidiano; têm experiência em utilização de e-mail e outros usos da web (jogos, downloads de música, clips, vídeos e vários tipos de arquivos). Todos afirmaram assistir TV várias vezes por semana; possuem celular há mais de dois anos e fazem uso dele várias vezes ao dia e, por fim, gastam muito tempo no trânsito para realizarem suas atividades.

A idade média dos participantes foi de 36 anos: a menor idade foi 25 anos e a maior 47 anos, sendo que a maior parte dos entrevistados (62\%) estavam na faixa entre 30 e 35 anos. Essa diferença da média de idade, em relação ao padrão da amostra européia (20 a 35 anos), pode ser explicada por questões sociais, específicas da 
realidade brasileira. Considerando a realidade do mercado de trabalho e sistema de remuneração no Brasil, pode-se constatar que o perfil econômico dos entrevistados que atendem aos critérios colocados(uso de PC, internet para e-mail, jogos, downloads de arquivos, multimídia complexa, celular, TV e independência financeira) e que têm condições de consumir os serviços oferecidos, corresponde a profissionais mais bem remunerados, com maior formação acadêmica, maior estabilidade financeira e, conseqüentemente, pertencentes a uma faixa etária um pouco mais avançada que a européia. Os cenários foram apresentados a grupos distintos, a saber: 11 viram o cenario John e 10 viram o cenário Helga. Os próximos itens mostram como isso foi realizado.

\subsubsection{Cenário Jonh Doe}

A tabela 5 mostra o original das questões feitas em todas as amostras, e para exemplificar, a figura 34 ilustra o serviço "Portal de Acesso, correspondente ao primeiro slide apresentado. A tabela descreve as questões em seu item J01..

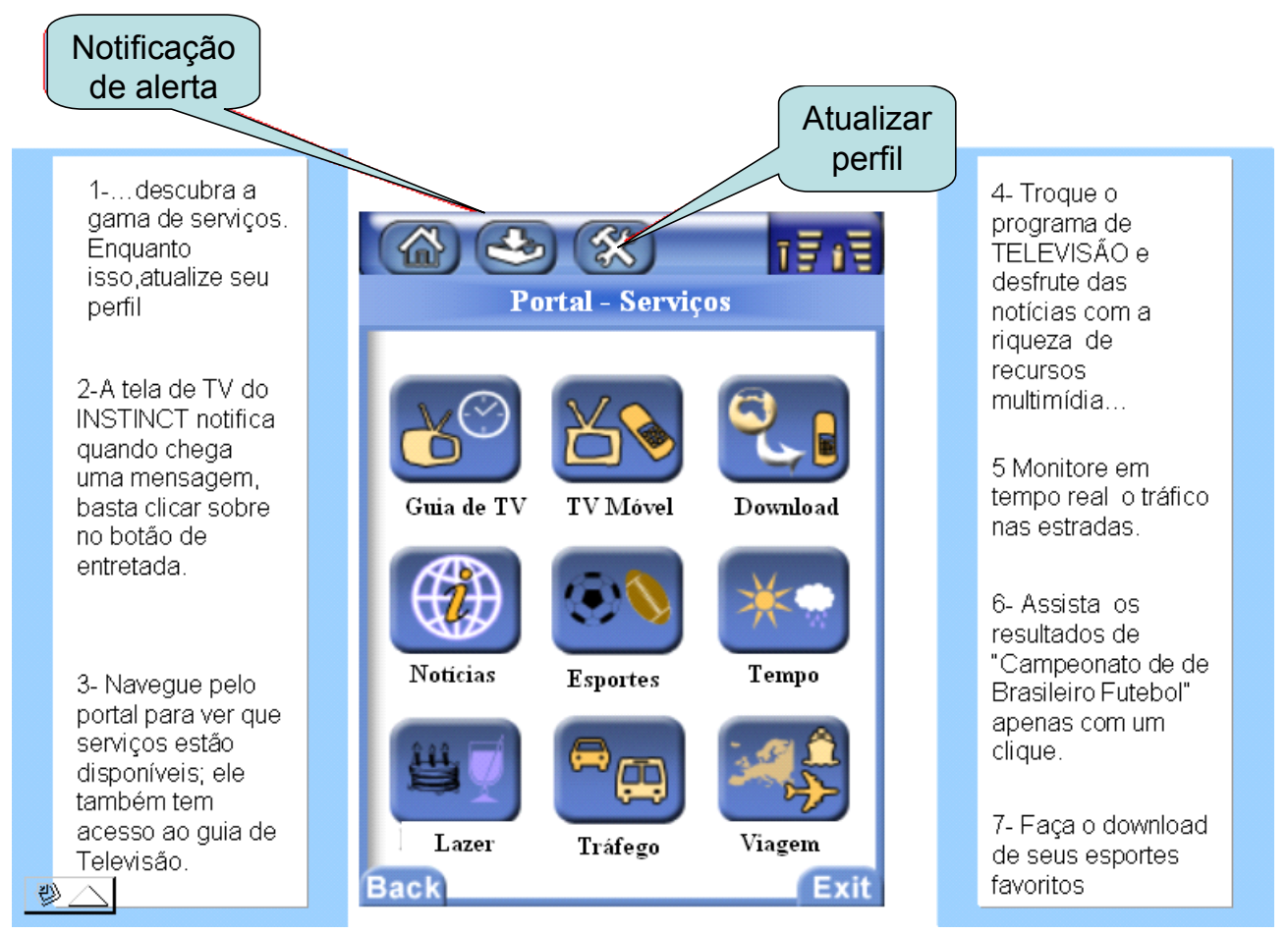

Figura 34 - Portal INSTINC - cenário John Doe 
Tabela 5 - Estrutura do questionário aplicado no cenário John Doe(original)

\begin{tabular}{|c|c|c|c|c|}
\hline $\begin{array}{l}\text { Task } \\
\text { Number }\end{array}$ & Service & $\begin{array}{l}\text { Reception } \\
\text { situation }\end{array}$ & Scenario component & Questions \\
\hline$J 01$ & Portal access & At home & $\begin{array}{l}\text { John connects to the } \\
\text { portal to discover the } \\
\text { whole range of provided } \\
\text { services. }\end{array}$ & $\begin{array}{l}\text { Can you give us an } \\
\text { example of a situation } \\
\text { when you would like to } \\
\text { receive this service? } \\
\text { Frequency? } \\
\text { Can you give us an } \\
\text { example of the content that } \\
\text { you would like to see in this } \\
\text { kind of service? }\end{array}$ \\
\hline J02 & $\begin{array}{l}\text { Authentification } \\
\text { and } \\
\text { Profile }\end{array}$ & At home & $\begin{array}{l}\text { After authenticating, he } \\
\text { can update his profile and } \\
\text { subscribe to additional } \\
\text { options }\end{array}$ & $\begin{array}{l}\text { Woulda be asked a gereral } \\
\text { question. I agree }\end{array}$ \\
\hline $\begin{array}{l}J 03, \\
J 04, \\
J 18\end{array}$ & $\begin{array}{l}\text { Multimedia alert } \\
\text { (notification): }\end{array}$ & $\begin{array}{l}\text { At home } \\
\text { On the } \\
\text { move }\end{array}$ & $\begin{array}{l}\text { The INSTINCT TV screen } \\
\text { gave him the list of alert } \\
\text { messages he received } \\
\text { during the night } \\
\text { Important messages start } \\
\text { a major alert ringing while } \\
\text { the terminal is in idle } \\
\text { mode } \\
\text { He will appreciate the } \\
\text { notifications and enjoy } \\
\text { watching the Tour de } \\
\text { France arrivals }\end{array}$ & $\begin{array}{l}\text { General question: } \\
\text { Can you give us an } \\
\text { example of a situation } \\
\text { when you would like to } \\
\text { receive this service? } \\
\text { Frequency? } \\
\text { Can you give us an } \\
\text { example of the content that } \\
\text { you would like to see in this } \\
\text { kind of service? } \\
\text { what do you want to } \\
\text { happened (??)when the } \\
\text { system is in idle mode } \\
\text { would you like to inhibit } \\
\text { them ? In which } \\
\text { circumstances? }\end{array}$ \\
\hline$J 05$ & SMS & At home & $\begin{array}{l}\text { The INSTINCT TV screen } \\
\text { gave him the list of the } \\
\text { SMS he received during } \\
\text { the night }\end{array}$ & $\begin{array}{l}\text { What is your actual usage } \\
\text { of SMS? } \\
\text { What is your actual } \\
\text { problems of SMS? } \\
\text { Not in "general cross- } \\
\text { scenario question"? }\end{array}$ \\
\hline
\end{tabular}

\subsubsection{Cenário Helga Schmidt}

A tabela abaixo representa todas as questões que foram feitas aos participantes através do slide (primeira coluna) e pelo ambiente do cenário (terceira coluna ). 
Tabela 6- Parte das questões relacionadas ao cenário Helga Schidt

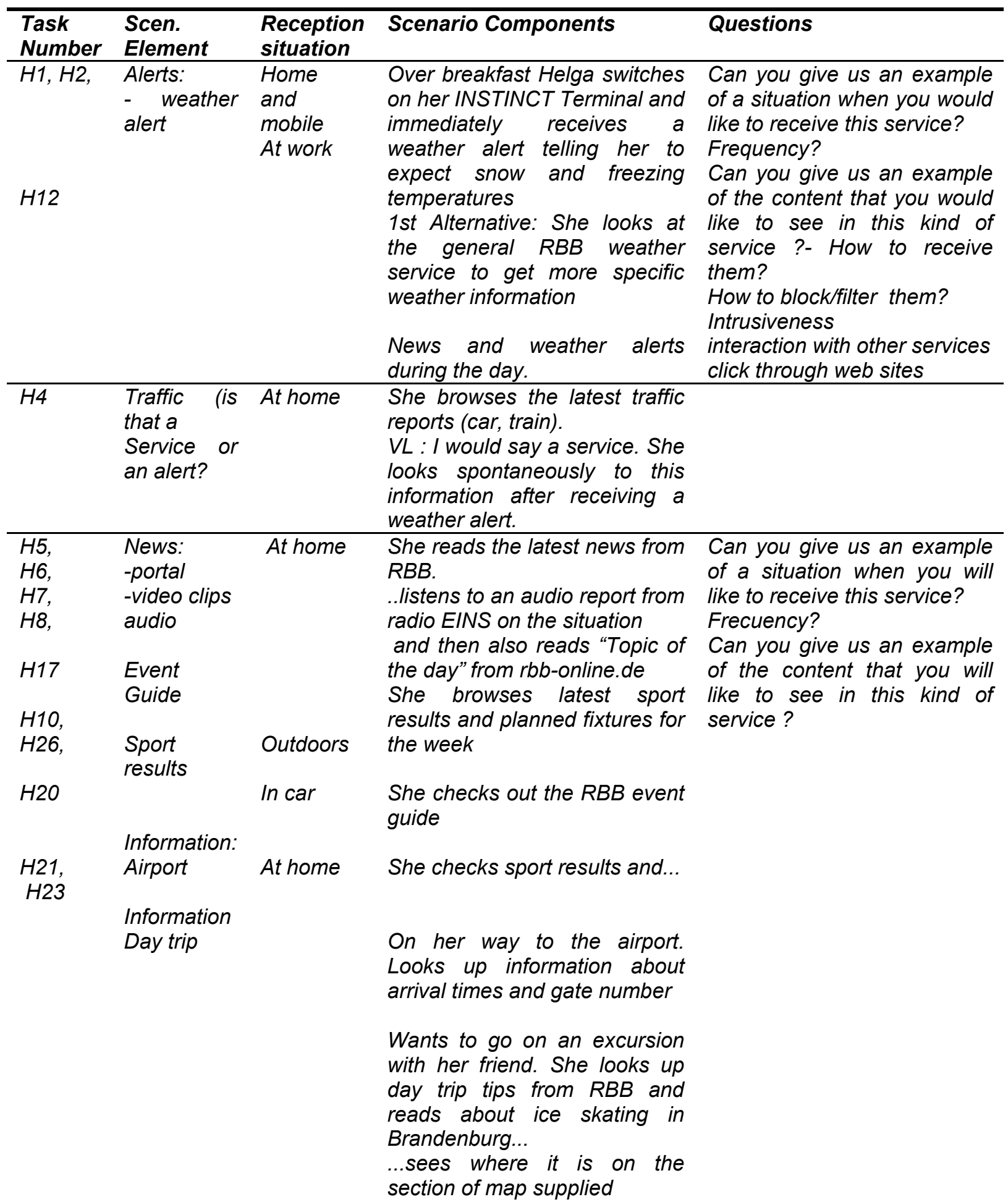

\begin{tabular}{ccl}
\hline$H 28$ & Sport $\quad$ Outdoors & $\begin{array}{l}\text { Looks up more information } \\
\text { about sport on the sport } \\
\text { programme's website }\end{array}$
\end{tabular}

Usage of Web in INSTINCT services (interaction with the rest of the services and portals):

What are your expectation abou the usage of web in several enviromments? How do you expect the interaction to be between the 


\begin{tabular}{|c|c|c|c|c|}
\hline & & & & $\begin{array}{l}\text { usage of web and the other } \\
\text { ways of presenting } \\
\text { information illustrated in the } \\
\text { scenario? }\end{array}$ \\
\hline$H 9$ & $\begin{array}{l}\text { News: } \\
\text { Voting } \\
\text { Event } \\
\text { Guide: } \\
\text { competition }\end{array}$ & At home & $\begin{array}{l}\text { She takes part in the vote: Are } \\
\text { the students right to continue } \\
\text { their strike action? } \\
\text { She enters a competition to } \\
\text { win tickets for the concert. }\end{array}$ & $\begin{array}{l}\text { Can you give us an example } \\
\text { of a situation when you will } \\
\text { like to receive this service? } \\
\text { Frecuency? } \\
\text { Can you give us an example } \\
\text { of the content that you will } \\
\text { like to see in this kind of } \\
\text { service? }\end{array}$ \\
\hline
\end{tabular}

\subsubsection{Análise dos resultados das entrevistas}

Os testes no Brasil ocorreram em São Paulo e nos próximos itens são apresentados os resultados obtidos diretamente nas entrevistas a partir das análises das respostas e anotações do psicologo, divididos nos diversos serviços.

Todos os entrevistados acharam útil e interessante poder ter acesso a um portal que integre diferentes possibilidades de serviços e que pode ser acessado a partir de diferentes meios: celular, PC, Lap-top, TV ou Palm. Além disso, a possibilidade de acesso a esses meios em qualquer lugar (trabalho, casa ou em movimento) agradou a todos os entrevistados. O diferencial, na opinião dos entrevistados, foi a possibilidade de poder acessar serviços semelhantes aos já conhecidos na Web, com a comodidade de acesso simples e rápido ao portal mesmo no trânsito.

Entre os entrevistados, houve uma certa preferência de utilizarem a TV para acessar o portal em casa utilizando o celular apenas quando em movimento. Durante o trabalho, apenas cerca de $15 \%$ dos entrevistados disseram que usariam o portal, esses entrevistaram disseram que permanecem conectados quase 8 horas por dia. Para eles, acessar a Web através do PC para obter serviços similares aos do portal é tarefa usual. Já serviços voltados ao lazer e entretenimento e aqueles que possibilitariam contato com outras pessoas para passar informações e organizar estratégias durante viagens, deveriam ser mais usados no acesso pelo celular, na opinião de $60 \%$ dos entrevistados. Outras observações foram:

Quanto à freqüência de uso do portal: $100 \%$ dos entrevistados alegaram que provavelmente o acessariam diariamente - alguns serviços tais como notícias e informações sobre o tráfego poderiam ser utilizados diariamente, enquanto os 
referentes a lazer, cultura, tempo e tv, entre outros, seriam acessados conforme a necessidade e interesse;

Quanto à forma de apresentação do portal: todos os entrevistados acreditam que a organização das informações e serviços disponibilizados é muito importante para que o portal seja eficiente. Quarenta por cento dos entrevistados que foram submetidos ao cenário Helga (sessão tipo A), opinaram que o portal é "visualmente poluído", muito carregado de informações, impedindo a localização rápida dos conteúdos específicos nos quais os usuários teriam interesse. Esses entrevistados sugerem que a tela seja mais "limpa", apenas com chamadas para conteúdos mais importantes ou usados com maior freqüência e com sub-menus para acessar conteúdos mais supérfluos. Sugeriram também que poderia haver a possibilidade de configuração da tela conforme o interesse ou a necessidade dos usuários. $O$ cenário John foi aprovado por $90 \%$ dos entrevistados que o discutiram (sessão tipo B) e apenas $10 \%$ deles sugeriram que o portal poderia ser esteticamente mais atraente (com design mais interessante), embora acreditem que o cenário seja adequado em termos de organização das informações.

Quanto aos conteúdos/serviços disponibilizados no portal: os entrevistados alegaram que muitos são interessantes e atendem às suas necessidades, e sugeriram alguns serviços e/ou conteúdos que consideram mais úteis ou que poderiam ser acrescentados ao sistema:

- Condições de tráfego: $90 \%$;

- Informações sobre o tempo: 86\%;

- Notícias gerais/política e economia: 60\%;

- $\quad$ Programação cultural (teatros, cinemas, museus): 60\%;

- Mapas: $30 \%$;

- $\quad$ Serviço de rotas: $30 \%$;

- Informações sobre turismo/ pacotes de viagens/hotéis: 25\%;

- Informações sobre linhas de ônibus: $25 \%$;

- Download de músicas e/ou outros arquivos: 25\%;

- S Serviço do tipo "Páginas Amarelas": 15\%;

- $\quad$ Guia de TV: $15 \%$;

- Culinária: $13 \%$;

- $\quad$ Acesso a serviços bancários: 10\%; 
- Dicionário: $10 \%$.

Quanto à necessidade de autenticação para o acesso ao portal e aos serviços disponibilizados: todos os entrevistados concordam com a importância de realização de algum meio para a identificação, parecido com a realizada no PC, com o objetivo de garantir a segurança dos dados. Observou-se que $80 \%$ dos entrevistados acreditam que a autenticação deveria ser realizada ao entrar no portal, não havendo necessidade de autenticar novamente ao acessar os diferentes serviços, a não ser as operações que envolvam informações confidenciais, como, por exemplo, compras on-line, em que é necessário o número de cartão de crédito etc. Cerca de $10 \%$ dos usuários responderam que não haveria necessidade de autenticar em nenhum momento e outros $10 \%$ acharam necessário autenticar a cada serviço acessado. Em relação à forma de autenticação, os entrevistados sugeriram que poderiam ser utilizadas senhas (letras e/ou números).

\subsubsection{Perfil}

Todos os entrevistados expressaram claramente suas expectativas em relação à necessidade do estabelecimento de perfis específicos, conforme as necessidades, interesses e características dos usuários dos serviços.

Cerca de $60 \%$ sugeriu que o sistema poderia oferecer duas possibilidades de perfil: um básico, com poucas opções, e um perfil complexo, com maior possibilidade de itens para personalização. A sugestão mais expressiva sugerida, com um percentual de $40 \%$, foi a de um "sistema inteligente" que se adaptasse e aprendesse a partir da rotina dos usuários. As opções mais citadas estavam relacionadas à definição do perfil, dentre elas:

- $\quad$ Os serviços a que gostariam de ter acesso;

- Escolha de conteúdos sobre os quais gostariam de receber alertas com informações;

- Configurar forma de recebimento dos alertas: tipos de alertas - sonoro ou visual - e em que momentos recebê-los.. 


\subsubsection{Possibilidade de recebimento de informações através de alertas}

Todos os entrevistados expressaram desejo de poder contar, no portal, com um serviço que lhes possibilitasse o recebimento de informações referentes a conteúdos específicos, sob a forma de alertas. Alegam que seria uma comodidade adicional poder receber as informações relevantes automaticamente, desde que o recebimento se restringisse apenas àqueles conteúdos considerados muito úteis e importantes para sua rotina, ou a notícias de eventos realmente excepcionais ou de grandes proporções; um exemplo citado foi um ataque terrorista. Para isso, esperam que o sistema possibilite alguma espécie de configuração para a definição de prioridade e do tipo exato de informação que deverá ser enviada. Suas expectativas foram de poder ter um lugar específico no portal em que essas informações fossem depositadas em tempo real e que pudessem ser acessadas a partir de algum tipo de ícone na tela, quando forem notificados de seu recebimento. Os entrevistados gostariam que as informações fossem resumidas e objetivas, assim como ocorre no SMS, com possibilidade de obterem informações complementares a partir de links. Houve divergências entre os entrevistados quanto à forma de notificação do recebimento de informações em alertas,. Cerca de 56 \% gostariam de ser notificados através de recursos visuais, por exemplo, algum ícone colorido ou piscando em um local específico da tela, sinalizando que existem mensagens. Outros $34 \%$ dos entrevistados alegam preferir algum tipo de sinal sonoro que os avisasse do recebimento de informações, porém com possibilidade de controle e/ou programação para momentos em que o sinal sonoro seria inconveniente como em reuniões ou cinema, por exemplo, e 10\% dos entrevistados não gostariam de receber notificações de recebimento e acessariam diretamente o local destinado às informações quando tivessem interesse. A partir da divergência de opiniões, ficou claro que o sistema deveria permitir algum tipo de programação em relação à forma de notificação, para que cada usuário pudesse utilizar o recurso da forma mais conveniente.

Todos gostariam que as informações continuassem a ser recebidas mesmo quando o sistema estivesse inativo e que o serviço que estivesse em uso no momento da chegada das informações não fosse afetado. 


\subsubsection{Conteúdos dos Alertas}

Sobre o conteúdo de alertas, houve uma divisão relativa ao assunto dos alertas. Os próximos itens abordam cada um dos assuntos.

\subsection{Notícias}

Cerca de $50 \%$ dos entrevistados disseram que gostariam de receber informações referentes a notícias sob a forma de alertas e que as informações fossem resumidas e objetivas, assim como no SMS, com possibilidade de obterem informações complementares caso o assunto seja de interesse. Sugeriram, ainda, que o acesso poderia ser a partir de links e que houvesse um lugar específico no portal no qual essas informações fossem depositadas em tempo real e que pudessem ser acessadas a partir de algum tipo de ícone na tela, quando recebessem a notificação ou a qualquer tempo.

Grande parte dos entrevistados, cerca de $80 \%$, disse que gostaria de receber informações sobre as principais notícias todos os dias, enquanto $20 \%$ deles preferira recebê-las apenas em casos de eventos excepcionais.

\subsection{Tempo}

Grande parte dos entrevistados, cerca de $80 \%$, achou que seria importante e útil para sua rotina diária poder receber informações referentes ao tempo sob a forma de alertas, para se programar quanto às condições de tráfego e roteiro de atividades, enquanto os $20 \%$ restantes acreditam que esse tipo de informação seria interessante apenas esporadicamente, como, por exemplo, no caso de viagens ou outras atividades fora de sua rotina.

Todos os entrevistados que gostariam de receber os alertas preferiam receber as informações diariamente, logo pela manhã, antes de sair de casa, e, em outros 
momentos do dia, em tempo real, mas apenas no caso de alguma ocorrência excepcional comoenchentes, acidentes ou desastres.

Os conteúdos considerados mais importantes pelos entrevistados foram: temperatura, condições climáticas locais e outras localizações específicas, mudanças bruscas no tempo, tempestades, inundações, entre outros.

\subsection{Tráfego}

A utilidade desse tipo de serviço nos cenários, foi citada por $90 \%$ dos entrevistados que gostariam de poder receber pelo portal informações sob a forma de alertas referentes às condições de tráfego nas principais vias de acesso da cidade ou rodovias.

Cerca de $70 \%$ afirmaram que essas informações seriam importantes para sua rotina e fariam uso delas diariamente, toda manhã antes de sair de casa, para programarem suas rotas para chegarem ao trabalho mais rapidamente e, ao final da tarde, nos horários de rush. Os outros 30\% acharam interessante o recebimento das informações no caso de terem que realizar atividades fora de sua rotina como, por exemplo, chegarem a pontos da cidade onde não estão acostumados a ir ou em viagens.

Os entrevistados manifestaram expectativa de poder receber informações resumidas através de links para terem acesso a imagens vindas de câmaras de rodovias e vias de acesso para visualizar as condições de tráfego. Também houve a expectativa de que o serviço permitisse o recebimento de rotas alternativas, estradas, mapas de acesso e informações sobre transportes coletivos (linhas de ônibus/metrô). Nesse caso, $15 \%$ dos entrevistados sugeriram receber esse tipo de informações a partir de arquivos sonoros, considerando que esse tipo de recurso facilitaria o acesso no caso do usuário estar em movimento, se locomovendo por pontos da cidade ou estradas e precisar de alguma informação. Cerca de 10\% sugeriu a possibilidade de interação do sistema com o GPS. 


\subsection{Esportes}

Cerca de $90 \%$ dos entrevistados declarou não ter nenhum interesse ou necessidade de receber informações sobre esportes no formato de alerta. Apenas 10\% dos entrevistados manifestaram interesse em receber alertas de esportes, mas, mesmo assim em situações muito específicas e esporádicas, como, por exemplo, finais de campeonatos expressivos.

\subsubsection{TV móvel}

Dentre os entrevistados, $70 \%$ declarou que não teria interesse em utilizar os serviços de TV móvel quando em movimento.

Cerca de $30 \%$ dos entrevistados demonstrou interesse em assistir TV enquanto estão em movimento, sendo que $18 \%$ deles apenas em ocasiões específicas como, por exemplo, durante viagens, no transporte para o trabalho, enquanto estão aguardando algum serviço específico ou ainda em função de alguma programação muito especial (final de campeonato, por exemplo). Apenas 12\% dos entrevistados demonstraram interesse em utilizaros os serviços de TV móvel de forma mais constante e em variadas situações.

Em geral, os usuários expressaram suas expectativas em relação à possibilidade de programar, de forma simples, os tipos de programas que normalmente gostariam de assistir e, quanto à qualidade da recepção, disseram que gostariam que fosse muito boa para possibilitar realmente a visualização na tela do celular.

Quanto ao tipo de programas que apreciariam assistir, a preferência foi por programas curtos, tais como noticiários, variedades, capítulos de séries, jogos, vídeoclips, enfim, programas cujo formato não exija muita concentração para seu acompanhamento. Filmes, por exemplo, todos preferem assistir em TV normal, sem interrupções. 


\subsubsection{Guias de programas de TV}

Parte dos entrevistados, $20 \%$, não expressou interesse em fazer uso desse tipo de serviço no portal, uma vez que, normalmente, em seu cotidiano, não necessitam regularmente desse tipo de informação, preferindo navegar entre os canais para ver a programação disponível. Afirmaram ainda ter o hábito de assistir a vários programas ao mesmo tempo, indo de um canal para outro através do controle remoto. Quando, ocasionalmente, querem programação específica, preferem obtê-la através do próprio serviço de tv a cabo ou através do PC.

O restante da amostra, $80 \%$, demonstrou interesse em poder realizar consultas à guias de programação de TV em diversas situações em movimento, seja para escolher com antecedência os programas que gostariam de assistir, seja para ficarem atualizados com o que existe de disponível na TV, ou ainda, para se programar para gravar algum programa interessante que não possam assistir no horário previsto em virtude de algum outro compromisso.

As sugestões sobre a forma de apresentação do conteúdo dos guias foram através da escolha por categorias de programas ou a partir da grade toda da programação das emissoras, com possibilidade de links com informações mais detalhadas, como resumo dos filmes, atores ou outros comentários.

\subsubsection{Interativos: quizzes, pop charts ,votting}

A maior parte dos participantes da pesquisa, cerca de $80 \%$, informou que normalmente não têm o hábito de participar desse tipo de atividade interativa, proposta na TV ou sites da internet, por não perceber muita utilidade ou retorno nelas. Assim sendo, não haveria interesse por parte deles em participar desse tipo de interatividade.

Os outros participantes (20\%), por sua vez, disseram que, embora não tenham o hábito de participar, poderiam vir a participar de propostas interativas sérias, emenquetes ou votações, sobre temas referentes à política, sorteios e pesquisas, cujo acesso e forma de participação fossem fáceis e rápidos. 


\subsubsection{Fóruns}

Embora uma pequena parte dos entrevistados, 25\%, não tenha demonstrado interesse em participar desse tipo de atividade interativa, a maioria dos entrevistados, $65 \%$, se manifestou de forma favorável quanto à possibilidade de participação em fóruns, por acreditar ser essa uma forma interessante de discutir um assunto ou temas específicos, tais como: saber a opinião de outras pessoas, obter mais conhecimentos/informações a respeito de algum assunto de interesse. Os entrevistados apresentaram sugestões sobre a utilidade e interesse em participar de fóruns, por exemplo, depois de entrevistas dadas em talk shows por especialistas, para obter mais informações, ou ainda, discutir algum aspecto abordado, como lugares para viajar, lançamento de produtos novos, entre outros. Os $10 \%$ restantes não souberam responder.

\subsubsection{Comunicação pessoal on-line com troca de mensagens}

Embora a grande parte dos participantes tenha dito, durante a entrevista, que não haveria interesse em entrar em chats com desconhecidos para participar de batepapos ou fazer novos amigos, alguns participantes, cerca de $35 \%$, revelaram fazer uso de comunicação pessoal on-line com bastante freqüência em suas horas de lazer para conversar com amigos, ou mesmo em atividades profissionais como, por exemplo, durante viagens para coordenar equipes de trabalho.

\subsubsection{Gravação de programas}

Cerca de $40 \%$ dos entrevistados declarou ter interesse em gravar programas em vídeo, mas apenas em situações esporádicas e muito específicas em que gostariam de assistir a um determinado programa em especial, mas não teriam condições devido a outros compromissos. Nesse caso, gravariam para assistir em outro momento mais conveniente. 
Alguns entrevistados, cerca de $30 \%$, disseram que, se o sistema de TV digital vier a oferecer um tipo de serviço que disponibilize os programas e filmes para assistir no horário em que lhes fosse conveniente, não haveria necessidade de gravar, pois os programas sempre estariam acessíveis.

\subsubsection{Compras on-line}

Todos os entrevistados avaliaram como positiva a possibilidade de poder realizar compras através do portal enquanto estão em casa ou em movimento, comprovando a utilidade do serviço oferecido em uma variedade de situações.

Alguns produtos que não foram apresentados especificamente nos cenários foram sugeridos pelos entrevistados, tais como: aparelhos eletro-eletrônicos, utensílios de cozinha, livros, CDs, ingressos para cinema /teatro/shows, entre outros.

\subsubsection{Assinatura de jornais/revistas}

A maior parte dos entrevistados, cerca de $60 \%$, demonstrou interesse em adquirir assinaturas de jornais ou revistas, referentes a conteúdos específicos para serem acessados através dos portais. Porém, houve a preocupação com o eventual custo adicional que esse recurso traria.

\subsubsection{Guia de eventos e locais de interesse}

Os entrevistados, em geral, acharam útil e interessante a possibilidade de ter acesso ao portal de informações históricas e culturais a respeito de locais específicos e serviços oferecidos, como: táxis, hotéis, restaurantes, pontos turísticos, cinemas, entre outros. Segundo suas opiniões, esses serviços poderiam ser utilizados por eles diariamente para obter informações a respeito da própria cidade ou, em ocasiões mais esporádicas, como em viagens em que necessitem saber o que existe de serviços disponíveis em outra cidade. 


\subsubsection{Análise dos resultados do Pós-Questionário}

A tabela 7 descreve, de forma resumida, os resultados obtidos a partir do pósquestionário. Como mencionado anteriormente, o objetivo desse questionário foi o de complementar os dados obtidos nas entrevistas e conferir maior consistência às informações coletadas.

Questões do teste do pós questionário Respostas dadas pelos entrevistados conforme o ambiente. Número de participantes que responderam às questões. (Brasil) 
Tabela 7- Resultados do Pós questionário

\begin{tabular}{ll}
\hline Onde você iria usar/consumir os serviços de TV digital? & \\
\hline Em casa & 14 \\
Outdoors & 12 \\
Trem / Ônibus & 6 \\
Todas anteriores & 4 \\
Nenhuma & 0 \\
\hline Que tipo de serviços você gostaria de consumir? & 18 \\
\hline Filmes & 17 \\
Controle do trafego & 13 \\
Shopping on-line & 11 \\
Informação sobre o tempo & 11 \\
Geral/Jornal local & 11 \\
Documentarios & 10 \\
Música /radio & 9 \\
Temas relacionados a cultura & 9 \\
Informações baseadas na Localização & 8 \\
Informação sobre viagens & 6 \\
Fotos & 5 \\
Chamadas de grupos & 4 \\
Jornais sobre esportes e destaques & 4 \\
Serviço de SMS & 3 \\
Canal de Filmes & 2 \\
Chat & 2 \\
Votos & 0 \\
Quiz shows & 0 \\
Jornal Financeiro & \\
\hline
\end{tabular}

Em que ambiente você gostaria de ter acesso a aos serviços oferecidos pela TV digital?

$\begin{array}{ll}\text { PC Tablet PC } & 3 \\ \text { Mobile Phone (3G) } & 14 \\ \text { PDA/Palmtop } & 7 \\ \text { Laptop } & 12 \\ \text { Nenhum } & 0 \\ \text { Outros } & 1\end{array}$

Você se interessaria em consultar seus serviços em vários terminais (seu terminal Instinct enquanto você esta na rua, em casa, etc....)

Sim 20

Conforme se pode observar na tabela 7 , os lugares mais escolhidos para o uso dos serviços foram, em primeiro lugar, a própria casa, seguido pela possibilidade de acesso quando em movimento. Esses resultados confirmam as informações obtidas durante a validação dos cenários.

Em relação ao tipo de serviços que gostariam de consumir, os 3 serviços preferidos foram filmes, compras online, e informações sobre o tráfego; todos com altos escores. No segundo grupo em ordem de importância estão os serviços de notícias, informações do tempo e documentários com resultados similares. Música e rádio, informação baseada na localização, informações culturais e turísticas são os 
próximos escolhidos pelos participantes. Todos esses serviços se referem também aos cenários que foram validados durante as entrevistas.

Por outro lado, serviços como trailers de filmes, notícias financeiras, notícias esportivas, chats, interativos, serviços de votos foram escolhidos por um número muito reduzido de participantes da amostra. Esses dados também confirmam as informações obtidas nas entrevistas, em que poucos entrevistados se mostraram interessados nesses serviços.

Foi ainda investigado o tipo de ferramenta que os participantes gostariam de usar nesse tipo de serviço. O celular, seguido pelo Lap Top, foram os equipamentos preferidos, seguidos pelo Palm e PC.

Quando questionados se teriam interesse consultar esses serviços a partir de vários tipos de terminais, todos os entrevistados demonstraram seu interesse, validando, portanto, tanto a entrevista quanto o próprio propósito do projeto INSTINCT.

\subsubsection{Análise dos dados obtidos a partir da amostragem brasileira}

Após análise do Pós-Teste, os dados confirmaram que os tipos de serviços oferecidos pelo portal foram, em sua maioria, considerados úteis e atraentes pelos entrevistados, que expressaram claramente seu interesse e disponibilidade para fazer uso deles em diferentes situações.

Os participantes acharam útil e interessante poder ter acesso a um portal que integrasse diferentes possibilidades de serviços que pudessem ser acessados a partir de diferentes ferramentas (celular, pc, lap top, TV ou Palm), conforme o contexto ou circunstâncias em que se encontrem (trabalho, casa ou em movimento). Concordam, ainda, que as informações precisam ser muito bem organizadas e fáceis de usar, e consideram atraente a possibilidade de receber informações importantes sobre conteúdos de seu interesse e necessidade sob o formato de alertas, especialmente em relação aos conteúdos de tráfego, condições do tempo e notícias em geral. A exceção foi em relação aos alertas e notícias sobre esportes. A análise dos resultados deixou clara a influência dos fatores socioeconômicos e culturais. A utilização de informações diárias sob o formato de alerta, referentes às condições do trânsito nas principais rodovias e vias de acesso se justificam, uma vez 
que os entrevistados vivem em uma grande metrópole, o teste foi realizado em São Paulo, que possui uma grande frota de veículos diariamente nas ruas e sofre com problemas de congestionamentos e inexistência de uma rede de transportes públicos e/ou coletivos que seja adequada à demanda. Observou-se, nas respostas, a preocupação com o tempo, ligada á possibilidade de complicações ainda maiores no trânsito em virtude de tempestades e alagamentos que são muito freqüentes na cidade, impedindo a locomoção das pessoas. Em momento algum, as respostas estavam relacionadas à programação de atividades ou viagens. Nesse sentido, a expectativa de um serviço que possibilite o acesso às rotas alternativas e mapas foi mencionado. Concluiu-se que usuários de outras capitais do Brasil, ou mesmo de outras grandes cidades dentro do próprio Estado de São Paulo, com potencial econômico compatível, não apresentariam os mesmos resultados, devido às divergências regionais e sua relação às preferências e utilidade de serviços.

Apenas $30 \%$ dos participantes do estudo validaram a relevância de assistirem TV enquanto em movimento, e, ainda assim, em circunstâncias bem específicas, como no caso de viagens longas ou longa espera de serviços em locais específicos. Para que esse serviço seja atrativo, os usuários apontaram a necessidade de que ele seja de boa qualidade e fácil de usar, bem como a seleção de programas. Imagina-se que a validação parcial desse tipo de serviço nas situações propostas pelos cenários possa ser justificada em função de características da própria amostra, constituída de pessoas que possuem jornadas de trabalho longas, com pouco tempo para o lazer, e também devido a características do próprio contexto cultural da cidade, que tem altos índices de criminalidade e furtos, principalmente de aparelhos mais sofisticados. Talvez, dados coletados em grandes cidades com outras características, pudessem oferecer outro resultado quanto ao uso desse tipo de serviço.

Outros serviços que foram considerados úteis e atrativos pelos participantes foram: a definição de perfis, a autenticação antes do uso dos serviços, compras on line, fóruns, informações turísticas e culturais. Em relação a serviços com possibilidade de pagamentos extras como, por exemplo, assinaturas para download de jornais e revistas, apesar de eles serem validados como relevantes e interessantes para diversas situações, parte dos entrevistados não revelou qualquer interesse em fazer uso deles em virtude de existir uma tendência cultural de se evitar esse tipo de serviço devido ao custo, que é bastante alto em relação a outros países. 
Os chats, serviços interativos e gravação de vídeos, também foram parcialmente validados nesse estudo. Poucos usuários usam chats, o que pode ser um efeito da amostra escolhida. Talvez usuários mais jovens oferecessem resultados diferentes. A relevância da possibilidade de gravar programas em vídeo está relacionada com a oportunidade de poder ter acesso a programas posteriormente.

Além de permitir a validação dos cenários, as entrevistas realizadas possibilitaram também o levantamento de algumas necessidades e expectativas mais específicas dos usuários, bem como a sugestão de outros serviços e possibilidades como, por exemplo, os recebimentos de alguns tipos de informações através de arquivos sonoros, ou a interface com o sistema GPS, para permitir o envio de informações mais específicas ao local em que o indivíduo se encontra.

Considerando a enorme diversidade física e cultural da realidade brasileira, chegouse à conclusão de que, para se ter uma mostra mais representativa desse tipo de trabalho em relação aos serviços e conteúdos apresentados em ambientes convergentes heterogêneos, seria interessante expandir a coleta de dados a outras cidades dentro do próprio Estado de São Paulo e a outras capitais com características diferentes. Esses testes teriam um maior custo pelas locomoções da equipe e tempo de aplicação.

\subsubsection{Comparação com os resultados europeus}

A tabela 8 apresenta, de forma sucinta, os resultados obtidos do trabalho realizado no Brasil, comparados com os resultados do trabalho feito na Espanha, relatados por Navarro. 
Tabela 8 - Comparação dos resultados brasileiro com o europeu

\begin{tabular}{|c|c|c|}
\hline & Amostra Espanha & Amostra Brasil \\
\hline $\begin{array}{l}\text { Local onde prefere } \\
\text { consumir os } \\
\text { serviços digitais }\end{array}$ & $\begin{array}{l}\text { Casa } \\
\text { Ônibus/trem } \\
\text { Trabalho } \\
\text { Em movimento }\end{array}$ & $\begin{array}{l}\text { Casa } \\
\text { Em movimento } \\
\text { Ônibus/trem } \\
\text { Trabalho } \\
\end{array}$ \\
\hline $\begin{array}{l}\text { Tipo de serviços } \\
\text { que gostaria de } \\
\text { consumir }\end{array}$ & $\begin{array}{l}\text { Noticias } \\
\text { Compras on line } \\
\text { Filmes } \\
\text { Informações do tempo } \\
\text { Trafego } \\
\text { SMS } \\
\text { Information storage } \\
\text { Fotos } \\
\text { documentários } \\
\text { Música } \\
\text { Localização à base da informação } \\
\text { Informações culturais } \\
\text { Informações sobre viagens } \\
\text { Esportes } \\
\text { Interativos (chats, quizz, votting) }\end{array}$ & $\begin{array}{l}\text { Filmes } \\
\text { Tráfego } \\
\text { Compras on line } \\
\text { Informações do tempo } \\
\text { Notícias } \\
\text { Documentários } \\
\text { Música } \\
\text { Informações Culturais } \\
\text { Localização à base da informação } \\
\text { Informações de viagem } \\
\text { Fotos } \\
\text { Group call } \\
\text { Esportes } \\
\text { Canal de traillers } \\
\text { Interativos }\end{array}$ \\
\hline $\begin{array}{l}\text { Cenários } \\
\text { totalmente } \\
\text { validados pelos } \\
\text { entrevistados, } \\
\text { cujos serviços } \\
\text { retratados foram } \\
\text { considerados úteis } \\
\text { e atrativos para } \\
\text { serem utilizados } \\
\text { em variadas } \\
\text { situações }\end{array}$ & $\begin{array}{l}\text { Portal de acesso aos serviços } \\
\text { Recebimento de informações sob o } \\
\text { formato de alertas } \\
\text { Possibilidade de configuração das } \\
\text { notificações de alerta } \\
\text { Alerta de notícias } \\
\text { Alerta de tempo } \\
\text { Alerta de tráfego } \\
\text { Possibilidade de configuração de perfil } \\
\text { Autentificação antes do uso } \\
\text { Compras on line } \\
\text { Fóruns } \\
\text { Informações culturais e turísticas } \\
\text { Uso de TV móvel } \\
\text { Atividades interativas/Votting services } \\
\text { Assinaturas de jornais/revistas e/ou } \\
\text { download de arquivos }\end{array}$ & $\begin{array}{l}\text { Portal de acesso aos serviços } \\
\text { Recebimento de informações sob o } \\
\text { formato de alertas } \\
\text { Possibilidade de configuração das } \\
\text { notificações de alerta } \\
\text { Alerta de tráfego } \\
\text { Alerta de tempo } \\
\text { Alerta de notícias } \\
\text { Possibilidade de configuração de } \\
\text { perfil } \\
\text { Autentificação antes do uso } \\
\text { Compras on line } \\
\text { Fóruns } \\
\text { Informações culturais e turísticas }\end{array}$ \\
\hline $\begin{array}{l}\text { Cenários } \\
\text { totalmente } \\
\text { validados pelos } \\
\text { entrevistados, } \\
\text { cujos serviços } \\
\text { retratados foram } \\
\text { considerados úteis } \\
\text { e atrativos para } \\
\text { serem utilizados } \\
\text { em variadas } \\
\text { situações }\end{array}$ & $\begin{array}{l}\text { Portal de acesso aos serviços } \\
\text { Recebimento de informações sob o } \\
\text { formato de alertas } \\
\text { Possibilidade de configuração das } \\
\text { notificações de alerta } \\
\text { Alerta de notícias } \\
\text { Alerta de tempo } \\
\text { Alerta de tráfego } \\
\text { Possibilidade de configuração de perfil } \\
\text { Autentificação antes do uso } \\
\text { Compras on line } \\
\text { Fóruns } \\
\text { Informações culturais e turísticas } \\
\text { Uso de TV móvel } \\
\text { Atividades interativas/Votting services } \\
\text { Assinaturas de jornais/revistas e/ou } \\
\text { download de arquivos }\end{array}$ & $\begin{array}{l}\text { Portal de acesso aos serviços } \\
\text { Recebimento de informações sob o } \\
\text { formato de alertas } \\
\text { Possibilidade de configuração das } \\
\text { notificações de alerta } \\
\text { Alerta de tráfego } \\
\text { Alerta de tempo } \\
\text { Alerta de notícias } \\
\text { Possibilidade de configuração de } \\
\text { perfil } \\
\text { Autentificação antes do uso } \\
\text { Compras on line } \\
\text { Fóruns } \\
\text { Informações culturais e turísticas }\end{array}$ \\
\hline Cenários & & Assinaturas \\
\hline
\end{tabular}


continuação

\begin{tabular}{|c|c|c|}
\hline $\begin{array}{ll}\text { validados } & \text { com } \\
\text { restrições } & \\
\end{array}$ & & $\begin{array}{l}\text { e/ou download de arquivos } \\
\text { Custos }\end{array}$ \\
\hline $\begin{array}{l}\text { Cenários } \\
\text { validados por } \\
\text { apenas parte dos } \\
\text { entrevistados }\end{array}$ & $\begin{array}{l}\text { Gravação em vídeos } \\
\text { Chats }\end{array}$ & $\begin{array}{l}\text { TV móvel } \\
\text { Gravação em vídeos } \\
\text { Chats }\end{array}$ \\
\hline $\begin{array}{l}\text { Cenários não } \\
\text { validados pelos } \\
\text { entrevistados, } \\
\text { cujos serviços } \\
\text { retratados não } \\
\text { foram } \\
\text { considerados } \\
\text { atrativos ou úteis }\end{array}$ & Alertas de esportes & $\begin{array}{l}\text { Alertas e notícias de esportes } \\
\text { Atividades interativas (quizzes, pop } \\
\text { charts, votting) }\end{array}$ \\
\hline
\end{tabular}

Observou-se que, apesar da amostra brasileira atender aos critérios que determinaram a escolha da amostra européia, ficaram evidenciadas algumas diferenças em termos qualitativos em relação aos resultados das duas amostras.

Existem variações em relação à preferência por determinados serviços que se mostram mais úteis em cada realidade estudada, e em relação à validação da utilidade de alguns serviços propostos nos cenários (TV móvel, atividades interativas/votting services, assinaturas e downloads de jornais, revistas) que provavelmente podem ser explicadas em função das variações das condições sociais e culturais de cada um dos países, que devem ser levadas em conta e que poderiam ser mais bem investigadas.

\subsubsection{Avaliação dos Resultados do trabalho}

Pôde-se verificar, através desse estudo, que, de forma geral, as opções de serviços oferecidos pelo Instinct, retratados nas diferentes situações propostas nos cenários que foram trabalhados com os sujeitos, foram, em sua maioria, considerados úteis e atraentes pelos entrevistados, que expressaram claramente seu interesse e disponibilidade para fazer uso deles em diferentes situações, permitindo, assim, a validação da maior parte dos cenários, uma vez que apenas alguns serviços apresentados não foram totalmente validados pela amostra de participantes.

Deve-se ressaltar, porém, que os fatores que provavelmente definirão realmente as possibilidades de escolha do portal estão relacionados ao custo, qualidade do serviço, cobertura e facilidade de acesso. 
As entrevistas realizadas permitiram a obtenção de importantes informações do ponto de vista qualitativo que, além de possibilitarem a validação da utilidade e atratividade dos vários tipos de serviços retratados nos cenários construídos para essa pesquisa, permitiram, ainda, o levantamento de algumas necessidades e expectativas mais específicas dos usuários, bem como a sugestão de alguns outros serviços e possibilidades considerados interessantes.

Ao serem comparados os dados obtidos junto à amostra brasileira com os dados obtidos junto à amostra da Espanha, relatados por Navarro, pôde-se verificar que, apesar de os sujeitos de ambas as amostras terem basicamente perfis muito semelhantes e viverem em grandes cidades economicamente comparáveis, e do processo de coleta de dados ter sido o mesmo, ficaram evidenciadas algumas diferenças entre seus resultados em relação à validação da utilidade de alguns serviços propostos nos cenários, destacando a preferência por determinados serviços, que se mostraram mais úteis e atrativos em uma das realidades estudadas. Tal diferença de resultados reforça a idéia de que os fatores sociais e culturais próprios de cada um dos países exercem influência sobre as preferências, necessidades e expectativas dos sujeitos em relação aos serviços oferecidos.

Ao serem analisados, em tópico anterior desse documento, os dados obtidos a partir da amostra brasileira, também se sugeriu que fatores físicos e culturais, relacionados às características próprias do contexto da cidade de São Paulo onde foram realizadas as entrevistas, possam ter determinado as necessidades dos usuários e conseqüentemente o tipo de serviço que foi considerado por eles útil ou relevante dentro dessa realidade específica.

Se for considerada a enorme diversidade física e cultural da realidade brasileira e analisados os dados obtidos, tanto sob o ponto de vista qualitativo quanto quantitativo, pensa-se que as informações obtidas a partir dessa amostra restrita de possíveis usuários podem não ser tão representativas do contexto brasileiro como um todo.

Tais reflexões apontam para a importância de ser investigada melhor essa questão a partir da ampliação e expansão do processo de coleta de dados, buscando captar as necessidades e expectativas de um maior número de possíveis usuários dos serviços oferecidos pelo INSTINCT, oriundos de grandes cidades de diferentes regiões brasileiras, permitindo assim o levantamento de uma perspectiva mais abrangente e realmente representativa do consumidor da América Latina, para se 
verificar a consistência dos serviços validados e possibilitar realmente a adoção em massa dos novos meios de acesso a conteúdos e serviços.

Assim sendo, recomenda-se o estudo das possibilidades de viabilização de uma continuidade no processo de coleta de dados. Considera-se que a Web se apresenta como um recurso bastante útil e interessante, capaz de permitir o acesso a amostras geograficamente e culturalmente distantes. O próximo item descreve uma proposta de trabalho nesse sentido.

\subsubsection{Avaliação de produtos e serviços através da Web}

Conforme discutido anteriormente, pode-se verificar, através dos estudos realizados com a amostragem de participantes brasileiros, que as opções de serviços oferecidos foram, em sua maioria, considerados úteis e atraentes pelos entrevistados, permitindo, assim, a validação da maior parte dos serviços oferecidos nos cenários, uma vez que, apenas alguns serviços apresentados não foram aceitos por todos os entrevistados.

As entrevistas realizadas permitiram a obtenção de importantes informações do ponto de vista qualitativo que, além de possibilitarem a comprovação da utilidade e atratividade dos vários tipos de serviços retratados nos cenários, permitiram, ainda, - levantamento de algumas necessidades e expectativas mais específicas, bem como uma coleta de sugestões de alguns outros serviços e possibilidades considerados interessantes dentro da realidade vivida pelos usuários.

Ao serem comparados os resultados da amostra brasileira com os resultados da amostra européia, percebe-se a existência de variações em relação à preferência por determinados serviços, que se mostraram mais úteis e atrativos em cada uma dessas realidades, em função da própria diversidade geográfica, social e cultural entre os contextos específicos pesquisados em São Paulo e na Espanha.

Ao ser considerada a enorme diversidade física e cultural existente entre as diferentes regiões de nosso país ou mesmo entre as grandes cidades de um mesmo Estado, foi levantada a dúvida de se os resultados obtidos a partir da amostra de usuários da cidade de São Paulo poderiam, do ponto de vista quantitativo ou qualitativo, ser considerados representativos da realidade brasileira como um todo, 
ou também se poderiam estar sujeitos a variações em relação à validação dos cenários, em função dessa diversidade.

Tais observações apontam para a importância da ampliação do processo de coleta de dados, buscando avaliar os serviços com uma amostragem maior de consumidores oriundos de grandes cidades de diferentes regiões brasileiras. $\mathrm{O}$ objetivo dessa ampliação foi possibilitar o levantamento de uma perspectiva mais abrangente e mais significativa para se verificar a consistência da avaliação de serviços e viabilizar a adoção do método

\subsubsection{Motivação para a ampliação da amostragem}

O Brasil é um país de dimensões continentais com mais de oito milhoes de $\mathrm{Km} 2$, composto por 27 Unidades da Federação e mais de cinco mil municípios existentes, abrangendo mais de 50 milhões de domicílios [IBGE,2005]. Essa dimensão territorial e a grande diversidade sócio-cultural impulsionaram a realização deste trabalho. Por motivos econômicos e facilidade de operação, foram escolhidas duas capitais brasileiras para a pesquisa aqui relatada, São Paulo e Manaus, geograficamente muito distantes e com características muito diversas.

São Paulo conta com uma população estimada em mais de 10 milhões de habitantes, 18 milhões na região metropolitana, ostenta o maior Produto Interno Bruto (PIB) do país e abriga o 1 milhão de habitantes que detêm metade da riqueza nacional [IBGE,2005].São Paulo é o centro econômico e industrial mais importante da América do Sul, abrangendo uma área de $250 \mathrm{mil} \mathrm{km}^{2}$. Manaus tem cerca de dois milhões de habitantes e é o centro comercial da Amazônia Brasileira que abrange uma superfície de cerca de 5 milhões de km2 [IBGE,2005] e que abriga a maioria da população indígena brasileira: cerca de 250 mil pessoas que falam quase duzentas línguas. Em 2005, as indústrias do Pólo Industrial de Manaus bateram todos os recordes; o faturamento conjunto das empresas incentivadas, que foi de US\$13,9 bilhões em fins de 2004, encerrou 2005 próximo dos US\$ 18 bilhões, um crescimento de ordem de $29 \%$. Esses dados refletem a diversidade socioeconômica do Brasil [IBGE,2005]. 
Avaliando a demanda de tempo e de trabalho de especialistas necessários para a realização de um número expressivo de entrevistas com os entrevistados em diferentes cidades e regiões do país, considerou-se que seria viável e mais interessante a possibilidade de ampliação do processo de coleta de dados a partir da utilização da Web, quer seja pela facilidade de implementação quer seja pela abrangência geográfica.

Os resultados obtidos deixaram evidente sua eficiência quanto a permitir que os consumidores expressassem suas necessidades e expectativas, e com base nesse diferencial a proposta Web teve como objetivo a continuidade do processo de avaliação de serviços dos mesmos cenários utilizados nas entrevistas. Desenvolvido por um psicólogo, o questionário projetado para Web foi desenvolvido de forma interativa e composta com questões específicas visando captar a opinião dos usuários em relação à utilidade e atratividade dos serviços retratados. A idéia proposta deveria complementar os dados obtidos nas entrevistas anteriores e verificar a consistência dos dados partir de uma amostra mais diversificada em termos de procedência regional e mais expressiva em termos numéricos.

Além disso, o objetivo da implementação do questionário foi comprovar a eficiência e adequação desse tipo de abordagem metodológica, o que pode vir a baratear esse tipo de avaliação em futuras aplicações.

\subsubsection{Avaliação pelo questionário Web}

A primeira fase do projeto deixou visível a impossibilidade de atender a uma gama maior de consumidores através de entrevistas pessoais devido às grandes distâncias entre os centros urbanos brasileiros e devido à discrepância regional, fatores evidentes nas características do país. O uso da WEB veio colaborar na descentralização do processo e diminuição dos custos de avaliação. Seguindo a mesma linha metodologia da versão anterior e utilizando os mesmos cenários, definiu-se uma maneira de questionar opiniões do consumidor através de navegação web sobre um conjunto de páginas adequadamente construído e com questões de múltipla escolha de forma a propiciar uma análise quantitativa sobre os dados de avaliação. As páginas foram planejadas de forma a simular o funcionamento de um 
equipamento, que foi definido para o cenário em questão, e com questões elaboradas com auxílio de um psicólogo que, idealmente, traria a mesma qualidade de informação obtenível nas entrevistas e com a facilidade adicional de poder ser respondida por muitos usuários potenciais de grupos previamente escolhidos e convidados.

O primeiro objetivo da avaliação assim definida era obter a validação dos cenários, reunindo diretamente as opiniões dos usuários sobre as situações e serviços retratados nas telas.

Dentro dessa interação, foram apresentados trechos dos cenários, telas do equipamento foram utilizadas na navegação juntando-se a elas as questões compostas de cinco alternativas seguindo o padrão sugerido por Navarro[Navarro,2003] referentes ao tema da tela e que indagam a opinião do usuário. Esse questionário foi elaborado pelo psicólogo na análise das respostas obtidas através das entrevistas pessoais realizadas na primeira fase deste trabalho.

\subsection{Cenário WEB: Portal INSTINCT}

A figura 35 mostra uma tela do questionário WEB. O entrevistado, assim chamado por conveniência na comparação com os demais testes, recebe um convite e algum incentivo para participar do teste. Ao acessar o portal, cujo link recebe na fase de negociação da sua participação, é recebido por uma tela de boas vindas e começa a navegação pela demonstração respondendo às perguntas concomitantemente. 
A tela inicial do portal INSTINCT é:

Bastante agradável e atrativa

Agradável, com informações adequadas

Adequada, mas poderia ser mais atrativa visualmente

Agradável, mas poderia conter mais informações Inadequada e pouco atrativa

Os serviços que à princípio são mostrados,em sua opinião são interessantes de serem acessados a partir de que tipo de equipamento?

celular.

TV.

Lap top

PC

Palm top

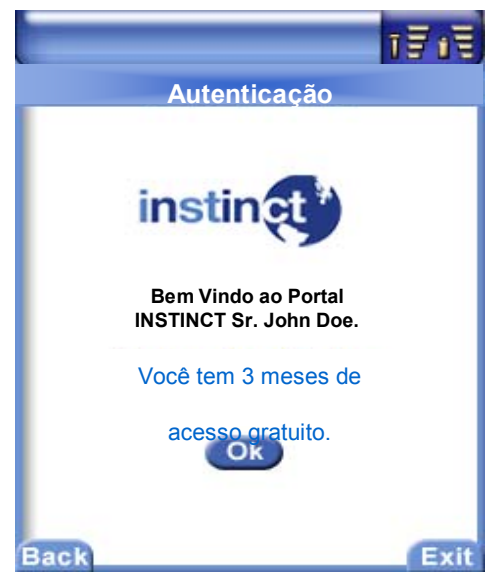

Figura 35 - Cenário do questionário Web

O teste de validação da proposta web não foi implementado pela web. Foi realizado através de navegação em papel por simulação e com um número reduzido de participantes para que as críticas pudessem ser recuperadas facilmente. Nenhum participante da primeira fase foi convidado, pois era importante que esse fosse 0 primeiro contato dos entrevistados com o portal e o teste.

A implementação da proposta Web foi realizada primeiramente em São Paulo com uma amostragem composta oito alunos da pós-graduação da Universidade de São Paulo, tendo em sua maioria profissionais envolvidos na área da informática. A faixa etária desse grupo estava na faixa de 24 a 43, e composta somente de homens. Em Manaus, a amostragem contou com 26 pessoas, sendo 24 homens e 2 mulheres sendo constituído de profissionais relacionados à área de informática e ensino. As idades desse grupo variaram de 23 a 52 anos. 
Os resultados obtidos, a dispeito da pequena amostragem, confirmam as hipóteses referentes à distância, à diversidade cultural e ao regionalismo são fatores relevantes nos produtos apresentados. Alguns dos serviços que foram considerados importantes para os entrevistados na região de São Paulo, como, por exemplo, informações sobre o transito, foram praticamente ignorados em Manaus. A inclusão de uma área para registros mais livres permitiu que os usuários opinassem mais livremente sobre os cenários e sugerissem novos serviços, bem como deu abertura para críticas sobre a maneira de apresentação dos cenários.

Os resultados confirmaram as expectativas abrindo novos rumos para a continuidade do trabalho, com o aperfeiçoamento do método baseado nas criticas e opiniões dadas pelos usuários de São Paulo e Manaus.

\subsubsection{Opinião dos entrevistados}

A primeira etapa do trabalho realizada por comparação entre São Paulo e Espanha conduziu à idéia da implementação do questionário via Web. Os resultados da segunda fase confirmaram a importância da ampliação do método bem como validaram os resultados anteriores.

As criticas e opiniões dos usuários de ambas amostras alertaram para um problema de grande importância: a interface humano-máquina e design para web.

De acordo com as criticas e opiniões recebidas, foram verificados os seguintes problemas:

- A navegação na implementação não foi amigável e a interatividade estava confusa;

- O cenário da Helga (Broadcasting) estava muito poluído. Os usuários consideraram abusiva a quantidade de informação para um ambiente de TV;

- $\quad$ O cenário John apresentou alguns trechos confusos para navegação;

- $\quad$ Os usuários afirmaram querer personalizar o ambiente de acordo com suas necessidades e interesses pessoais;

- $\quad$ Os usuários questionaram a falta de interatividade com outros usuários;

- $\quad$ O desing estava muito pobre. 
Diante destes resultados acredita-se que será necessário um cuidado especial nos conceitos referentes aos atributos de sistemas e aplicações baseados na Web. Portanto, a primeira sugestão para uma próxima etapa é montar um plano de trabalho referente à estrutura da avaliação através da WEB. 


\section{CONSIDERAÇÕES FINAIS}

Foi proposto um modelo de trabalho para avaliar a aceitabilidade de produtos, incluindo serviços, softwares, equipamentos e modelos de negócio cuja eficácia ficou comprovada através de estudos de caso e experimentos em projetos. Foi também proposta uma alteração nesse modelo que se demonstrou eficiente e eficaz, pois trouxe resultados equivalentes com um custo muito inferior.

O trabalho foi nitidamente multidisciplinar, pois teve que buscar respaldo técnico em áreas não antes assistidas pela engenharia de sistemas. Utilizaram-se conhecimentos da engenharia de computação, da engenharia de sistemas e da psicologia, estando ainda abertos os campos para trabalhos em economia, marketing e etc. $O$ ser humano não é entendido numa determinada área de conhecimento pela sua complexidade. As reações aos estímulos são sempre complexas e se devem a influências de toda ordem, principalmente das experiências anteriores do próprio indivíuo analisado.

Avaliando-se os objetivos originais do trabalho pode-se dizer que:

- Definição de um modelo de avaliação de aceitabilidade de produtos: Considerase que o modelo que foi proposto atende plenamente às necessidades de avaliação de aceitabilidade de um produto ou serviço, sendo extremamente interessante do ponto de vista da apresentação nas fases iniciais de um novo desenvolvimento devendo garantir uma boa margem de acerto nos experimentos realizados, como demonstrado nos estudos de caso;

- Definir o uso de técnicas e ferramentas multidisciplinares: Considera-se que o trabalho atende plenamente esses objetivos, pois buscou técnicas da engenharia da qualidade, da engenharia de produção, da engenharia de sistemas e da engenharia da computação, além de se basear nos conhecimentos da psicologia. Todos esses conhecimentos estão se tornando parte integrante necessária e não suficiente da área do conhecimento que se delineia como Fatores Humanos no Projeto de Sistemas;

- Definir o uso de técnicas e ferramentas de áreas diversas do conhecimento: Como já observado no item anterior, esse objetivo foi plenamente atendido, 
deixando ainda aberturas para outras áreas que compões a multidisciplinaridade necessária para o entendimento do comportamento de grupos de pessoas. Essa característica tende a convergir uma area de conhecimento ainda mais interessante que deve vir a ser um novo paradigma nos projetos, a transdisciplinaridade, ainda não definida no uso da engenharia;

- Avaliar a aceitabilidade de produtos: Esse objetivo particular não somente foi atendido como resultou em um trabalho muito interessante relatado sucintamente nos estudos de caso apresentados no capítulo cinco, gerando conhecimento da área e trabalho para profissionais brasileiros que trabalharam nas avaliações e definições de novos serviços convergentes em redes e ambientes heterogêneas envolvendo TV Digital, Telefonia móvel e fixa e Internet através dos Projetos Voices In Your Hands, patrocinado pela Philips e INSTINCT patrocinado através do IST - Information Society Technology pela Comunidade Européia;

- Fazer uso da Tecnologia WEB: O objetivo de fazer uso da WEB para facilitar o processo de aquisição de dados de aceitabilidade de produtos, diminuindo os custos de implantação dos testes foi alcançado plenamente com o modelo modificado para essa finalidade. O modelo WEB foi testado e trouxe resultados muito próximos àqueles conseguidos com a aplicação do modelo original presencialmente;

- Verificar fatores externos que influenciam os resultados obtidos: Esse objetivo foi atendido como pode ser verificado pelas diferenças obtidas nas aplicações da avaliação em diferentes populações demonstrando a diferença dos interesses entre diferentes comunidades. Populações semelhantes do ponto de vista socio-econômico demonstraram interesses comuns muito próximos enquanto populações de diferentes áreas geográficas ou culturas demonstraram essas diferenças na aceitação dos serviços propostos na avaliação. O modelo demonstrou semelhanças e diversidades com boa precisão, como pode ser avaliado no capítulo cinco.

Para finalizar o trabalho resultou em um artigo intitulado Consumer Information Gathering for Convergent Systems - Human Centered Design [MENDES,2006]. 


\subsection{Contribuições}

A principal contribuição deste trabalho foi a elaboração de um modelo e de procedimentos para sua aplicação que podem ser utilizados como apresentados, a baixos custos, para a avaliação da aceitabilidade de novos produtos ou serviços a diferentes grupos potenciais de consumidores.

A modificação desse modelo de avaliação para uso através da Internet é uma outra contribuição importante. O modelo WEB, como foi chamado, foi também testado e demonstrou suas qualidades como equivalentes ao modelo presencial.

\subsection{Trabalhos futuros}

Como já mencionado, os estudos de caso comprovaram a eficácia no modelo de avaliação de serviços em todos os requisitos abordados nos objetivos.

Como comentado nos estudos de caso, houve reclamações dos entrevistados com respeito à navegação no modelo desenvolvido. Isso leva a uma dúvida no design de interação que precisa de novos testes e, provavelmente, um estudo específico.

A avaliação dos serviços ficou comprometida pela velocidade da conexão e dificuldades de navegação diminuindo o número de respostas completas ou utilizáveis, comprometendo, ate certo ponto os resultados encontrados. Fleming (1998) descreve como um melhor design de interação poderia ter ajudado na avaliação do mockup do modelo WEB.

Esta crítica surgiu depois da avaliação. Como descrito em Hix e Hartson (1993), o designer interativo é responsável por desenvolver o conteúdo, contexto e aparência. Um trabalho mais elaborado na usabilidade do mockup possivelmente teria modificado significativamente as respostas obtidas, pois mais pessoas teriam respondido e respondido melhor às questões que foram propostas.

O trabalho pode ser muito enriquecido através de novos estudos em usabilidade na navegação e com uma ainda maior interação com os profissionais das áreas humanas do conhecimento. 


\section{REFERÊNCIAS BIBLIOGRÁFICAS}

AKAO, Y. Introdução ao desdobramento da qualidade. Belo Horizonte: Fundação Christiano Ottoni, 1996. 187 p.

ALBRECHT, K. Revolução nos serviços. 2. ed. São Paulo: Pioneira, 1992.

Serviços com qualidade: vantagem competitiva. São Paulo: Makron Books, 1992.

. O pensamento gerencial precisa descobri o usuário e o serviço. Folha Management. São Paulo, n.4, 4 set., 1995a. p.1-4.

Programando o futuro: o trem da linha norte. São Paulo: Makron, 1995b.

Revolução nos serviços: como as organizações podem revolucionar a maneira de tratar os seus usuários. São Paulo: Pioneira, 1998.

BARANAUSKAS, M. C. C.; ROCHA, H. V. Design e Avaliação de Interface Homem-Computador. São Paulo: UME-USP, 2000.

BARBÊDO, Simone Angélica Del-Ducca. Sistema de gestão da qualidade em serviços: estudo de caso em uma biblioteca universitária. 2004, $134 \mathrm{f}$. Dissertação (Mestrado em Engenharia de Produção) - UNIFEI, Itajubá, 2004. Disponível em: <http://www.ppg.efei.br/cpgp/Dissertacao/2004/89.pdf>. Acesso em: 26 nov. 2004.

BARTH, Fabrício Jailson; MINDLIN, P.A.; SPINA, Edison; GABOS, Denis. CONE convergent heterogeneous netwoks QOS evaluation tool. In: IBC 2005., Amsterdam, Netherlands, 200. Conference Publication. Amsterdam. p. 381-388

BEVAN ,NIGEL. Quality in Use: Meeting User Needs for Quality. Journal of System and Software, 1999.

BLACKWEEL , ROGER. HSM Management 37. março-abril, 2003. Campus, 1999. 
BORGES, A.T. Como Evoluem os Modelos Mentais. Ensaio. Pesq.Educ.Ciênc., v. 1, n.1, p. $85-125$, set. 1999.

BROOKE, J. SUS: a ‘quick and dirty’ usability scale. 1996 In JORDAN, P. W.; THOMAS, B; WEERDMEESTER, B. A.; MCCLELLAND, I. L. (Eds.) Usability evaluation in industry. London: Taylor \& Francis. p. 189 -194.

CAÑAS, J.J; WAERS, Y. Ergonomia Cognitiva: Aspectos Psicológicos de la Interacción de las Personas con la Tecnologia de la Información. Ed. Medica Panamericana, 2001.

CARNEVALLI, José Antonio; SASSI, Andreza Celi; MIGUEL, Paulo A. Cauchick. Aplicação do QFD no desenvolvimento de Produtos: levantamento sobre seu uso e perspectivas para pesquisas futuras. Gestão \& Produção, v.11, n.1, p.3349, jan.-abr. 2004.

CHENG, L . C; SCAPIN, C. A; OLIVEIRA, C.A.; KRAFETUSKI, E.; DRUMOND, F.B.; BOAN, F.S.; PRATES, L.R.; VILELA, R.M. Planejamento da Qualidade. Belo Horizonte: UFMG, Escola de Engenharia, Fundação Cristiano Ottoni: Ed. Littera Maciel Ltda. 1995. p. 261.

CORTÉS, Dina María Medem; SILVA, Carlos Arthur Barbosa Da Braz. (Rev) Desdobramento da Função Qualidade-QFD - Conceitos e Aplicações na Indústria de Alimentos. J. Food Technol., v.8, n.3, p. 200-209, jul./set. 2005.

CASTELLS, M. A Sociedade em Rede: A era da informação: economia, sociedade e cultura. v. 1. São Paulo: Paz e Terra. 1999.

CASTI, J.L. Paradigms lost: images of man in the mirrar of science. New York: William Morrow,1989.

CARROLL J., M.; ROSSON M., B. Getting Around the Task-Artifact Cycle: How to Make Claims and Design by Scenario. ACM Transactions on Information Systems, v. 10, n. 2, 1992. p. 181-212.

Making use A Design of the ACM. v. 37, n. 12, 1994.

. (ed). Scenario-based design: envisioning work and technology in system development. New York, Wiley. 1995. 
Five reasons for scenario-based design Interacting with Computers

13. 2000. p. 43-60.

Making use: Scenario-based design Lawrence Erlbaum Associates. 2002, p. $1032-1050$.

.; ROSSON M., B. Scenario-Based Design, The Human-Computer Interaction Handbook: Fundamentals, CHI 2005, April 2-7, 2005, Portland, Oregon, USA. Evolving Technologies and Emerging Applications. Lawrence Erlbaum Associates, 2002, p. 1032-1050. Computer Interaction", Addison-Wesley.

CARD, S.; MORAN,T.; NEWELL A. The Psychology of Human-Computer Interaction. Hillsdale, NJ: Lawrence Erlbaum Associates. 1983.

CHIAVENATO, I. Teoria Geral da Administração 6. ed. Rio de Janeiro: Campus, 1985.

COBRA, Marcos. Marketing Básico: Uma Abordagem Brasileira. 4. ed., São Paulo: Atlas 1997.

CRUZ, C; RIBEIRO, U. Metodologia Científica: Teoria e Pratica $1^{\circ}$ Ed. Rio de Janeiro. Axcel Books do Brasil, 2003. p 218.

CYBIS, Walter De Abreu. Engenharia de Usabilidade: uma abordagem Ergonômica - LABiutil. Prof. Walter de Abreu Cybis. Engineering - RE97, p. 44-53. IEEE Computer Society Press, jan, 1997. Disponivel em:

<http://www.labiutil.inf.ufsc.br/Apostila_nvVersao.pdf>.

CHIN, J. P., DIEHL, V. A.; NORMAN, K. L. Development of an Instrument Measuring User Satisfaction of the Human-Computer Interface. In: ACM CHI'88 Conference. Proceedings. Washington, DC, 1988. p. 213-218.

DEORA, V.; SHAO, J.; GRAY, W. A. FIDDIAN, N. J. A Quality of Service Management Framework Based on User Expectations. ICSOC 2003. LNCS 2910, p. 104-114, 2003.

DILLINGER, K; MADANI, N. Alonistioti. (Ed.) Software Defined Radio: Architectures, Systems and Functions. John Wiley \& Sons. p 27- 45. 
ENGEL, J. F.; BLACKWELL, R. D.; MINIARD, P. W. Comportamento do

Consumidor. 8. ed. Rio de Janeiro: LTC, 2000.

EUREKA, William E.; RYAN, Nancy E. QFD Qualitymark, 1993.

EYSENCK, Michael W.; KEANE, Mark T. Psicologia cognitiva: manual introdutório. Porto Alegre: Artes Médicas, 1994.

FLEMING, J. Web Navigation: Designing the User Experience. O'Reilly, Beijing, 1998.

GADE, C. Psicologia do consumidor. São Paulo: EPU, 1980.

GALLIANO, A. G. Introdução à sociologia. São Paulo: Harper \& Row do Brasil, 1981.

GARVIN, David A. Gerenciando a Qualidade: A Visão Estratégica e Competitiva. Rio de Janeiro: Qualitymark, 2002.

GIANESI, I. G.N.; CORRÊA, H.L. Administração estratégica de serviços. São Paulo: Atlas, 1996.

GRONROOS, C. Marketing: gerenciamento e serviços - a competição por serviços na hora da verdade. Rio de Janeiro: Campus, 1993

GUINTA, LAWRENCE R / PRAIZLER, NANCY C Manual de Qfd LTC, 1993.

GUMMESSON, E.; GRONROOS, C. Quality of services: lessons from de product sector. Chicago, III.: American Marketing Association, 1988.

Marketing, gerenciamento de serviços: a competição por serviços na hora da verdade. Rio de Janeiro: Campus, 1995.

. Service quality: the six criteria of good service quality. Review of Business, Nova York, n.3, p. 12, 1988. 
HERNON, P.; ALTMAN, E. Assessing service quality: satisfying the expectations of library customers. Chicago: American Library Association, 1998. p. 243.

HIX, D.; HARTSON, H. Developing User Interfaces: Ensuring Usability Through Product \& Process. John Wisley \& Sons, 1993.

HOLLNAGEL, E. Cognitive Ergonomics: It's all in the Mind. Ergonomics, n. 40, v. 10. 1997. p. 1170-1182.

IBGE -INSTITUTO BRASILEIRA DE GEOGRAFIA E ESTATÍSTICA - IBGE. Disponível em: http://www.ibge.gov.br. Acesso em:Jan. 2006.

\section{INSTINCT IP-BASED NETWORKS, SERVICES AND TERMINALS FOR} CONVERGING SYSTEMS - INSTINCT. Disponível em: http://www.ist-instinct.org.

ISO 13407. Human-centred design processes for interactivesystems. 1999. Disponível em: http://www.usabilitynet.org/tools/13407stds.htm>. Acesso em: Jan. 2006.

ISO/IEC, 13407 Human-Centered Design Processes for Interactive Systems. 1999: In: M. ISO/IEC 13407:1999. User Requirements for SDR Terminals. 2003.

JACOBSON, I.; BOOCH, G.; OVERGAARD, G. Object Oriented Software Engineering: A Use Case Driven Approach. Ed. Addison-Wesley, 1992.

JOHNSON-LAIRD, P. Mental models. Cambridge, MA: Harvard University Press, 1983.

The computer and the mind: an intraduction to cognitive science. Cambridge, MA: Harvard University Press, 1988.

JOHNSTON, R.; CLARK, G. Administração de Operações de Serviços. São Paulo: Atlas, 2002.

JORDAN, P.W. An Introduction to Usability. London, UK: Taylor \& Francis, 1998. 
JEFFRIES, R.; MILLER, J. R.; WHARTON, C.; UYEDA, K. M. User interface evaluation in the real world: A comparison of four techniques. Procedings of CHI91, 119-124. New York, NY: 1991.

KARAM JUNIOR, DIB, Modelo de negócio para mobilidade e interatividade em ambientes convergentes heterogêneos. 2006. Tese (Doutorado em Sistemas Digitais) - Escola Politécnica, Universidade de São Paulo, 2006.

KARSAKLIAN, Eliane. Comportamento do Consumidor. São Paulo: Atlas, 2000.

KARWOWSKI, W. IEA Facts and Background. Louisville: IEA Press, Jan., 1996. p. 43.

KOLASA, B. J. Ciência do comportamento na administração. Rio de Janeiro: Livros Técnicos e Científicos, 1978.

KOTHLER, Philip; ARMSTRONG, Gray. Princípios de marketing. Rio de Janeiro: Prentice-Hall do Brasil, 1993. Brasil, 1993. p. 477 . Princípios de marketing. 5. ed. São Paulo: Prentice-Hall do Administração de marketing. São Paulo: Atlas, 1996.

Administração de marketing: análise, planejamento, implementação e controle. 5. ed. São Paulo: Atlas, 1998.

Administração de marketing. São Paulo: Novo Milênio, 2000.

Marketing para o século XXI: como criar, conquistar e dominar mercados. São Paulo: Futura, 2003.

LAS CASAS, A.L. Qualidade total em serviços: conceitos, exercícios, casos práticos. São Paulo: Atlas, 1995.

Qualidade total em serviços: conceitos, exercícios, casos práticos. 3. ed. São Paulo: Atlas, 1999. 
LEITE, J. C. S. P., et al. Enhancing a Requirements Baseline with Scenarios. Third IEEE International Symposium on Requirements Engineering - IEEE Computer Society Press. Los Alamitos, Ca, USA. 1997.

LEITE, J.C.S.P; ROSSI, G.; BALAGUER, F.; MAIORANA, V., Enhancing a requirements baseline with scenarios. In Proceedings of the Third IEEE International Symposium on Requirements Engineering - RE97, p. 44-53. IEEE Computer Society Press, London: Springer-Verlag. Jan, 1997.

LIMA, Gercina A. Borém. Interfaces entre ciência da informação e ciência cognitiva. Ciência da Informação, v. 32, n. 1, p.77-87. jan./abr. 2003. Disponível em: <http://www.ibict.br/cienciadainformacao/ viewarticle.php?id=166\&layout=abstract>. Acesso em: 2006.

LLOPOIS, P.A et al. An Approach on Integrated WDM and IP Network Management: The Winman Project. Comunicaciones de Telefónica I+D. n23, 2001.

LOJKINE, JEAN. A revolução informacional. São Paulo: Cortez, 1999.

LOVELOCK, Christopher; WRIGHT, Lauren. Serviços: marketing e gestão. São Paulo: Saraiva, 2001.

São Paulo: Saraiva. 2003, p. 416.

Serviços: marketing e gestão Tradução de Cid Knipel Moreira.

MAIA, R. F. et al. A framework to Mobility to Mobility and Interactivity for Convergent Technologies. 2005.

MARCONI, M, LAKATOS; E. Metodologia Cientifica, 4º ed. São Paulo; Atlas, 2004. p. 305.

MARMARAS, N.; KONTOGIANIS, T. Cognitive Task. In: SALVENDY, G. 2001.

MARTUCCI, $M$ et al Mobilidade e Interatividade em um ambiente de convergência tecnológica. SUCESU, may, 2005. 
Mediadas por Aparato Tecnológico. (Dissertação não publicada) Instituto de Psicologia da Universidade de Brasília. UnB, Brasília.

MENDES, Joyce Martins; PRIETO, Raquel Navarro ; SPINA, E. . Consumer Information Gathering for Convergent Systems - Human Centered Design. The 2006 International Conference on Information \& Knowledge Engineering - IKE'06, 2006, Las Vegas - USA. Proceedings of The 2006 International Conference on Information \& Knowledge Engineering - IKE'06. Georgia - USA : C.S.R.E.A. Press Computer Sciences Research, Education and Applications, 2006. p. 375-382

MILLER, P. H.; MILLER, S. A. Desenvolvimento cognitivo. 3. ed. Porto Alegre: Artmed, 1999.

MORAES, Anamaria de. O projeto ergonômico de espaços de trabalho: Exemplos de estações de trabalhos informatizados. In: LAMBRETS, R.; GONTIJO, Gerges, S.; PHILIPPI, P.; PEREIRA, F. (org) Anais do $2^{\circ}$ encontro Conforto no ambiente. Florianópolis: ANTAC:ABERGO:SOBRAC, 1993, p. 363-372.

NAVARRO-PRIETO, R., CONATY, G. (2003) User Requirements for SDR Terminals. In: DILLINGER, M.; MADANI, K.; ALONISTIOTI, N. (Ed) Software Defined Radio: Architectures, Systems and Functions. John Wiley \& Sons. p. 27- 45.

NEVES, Dulce Amélia. Ciência da informação e cognição humana: uma abordagem do processamento da informação; Ci. Inf., Brasília, v. 35, n. 1, p. 39-44, jan./abr. 2006.

NIELSEN, Jakob, Usabilty Engineering. San Francisco: Morgan Kaufmann, Inc, 1993.

. Heuristic Evaluatin. In: (ed.) Usability Inspection Methods. New York: John Wiley, 1994.

Heuristic Evaluation. In: .; MACK, R (Eds.) Usability Inspection Methods. New York: John Wiley \& Sons, INC. 1994-1998. Disponível Em: $<$ Http://Www.Useit.Com/Papers/Heuristic/>.

Ten Usability Heuristic. In .; MACK, R. (eds) Usability Inspection Methods. New York: John Winley \& Sons. 1999. Disponível em: $<$ http://www.useit.com/papers/heuristic/heuristic.html>. 
NORMAN, Donald A. Things That Make Us Smart: Defending Human Attributes in the Age of the Machine. New York, Addison-Wesley Publishing. 1993.

\section{. Emotional Design: Why We Love (Or Hate) Everyday Things}

(Hardcover). Basic Books, 2003.

OLLNAGEL, E. Cognitive Ergonomics: It's all in the Mind. Ergonomics, n. 40, v. 10, 1997. p. 1170-1182.

PAIVA, C. C. S. Nível de qualidade dos serviços bancários no ambiente digital. 2001. 215 f. Dissertação (Mestrado em Engenharia de Produção) - Programa de Pós- Graduação em Engenharia de Produção, UFSC, Florianópolis. 2001.

PAIVA, Caroline Liboreiro. A implantação do processo de desenvolvimento de Novos produtos em uma pequena empresa de Massas alimentícias, utilizando o método de Desdobramento da função qualidade (QFD).

PARASURAMAN, A.; ZEITHAML, V. V.; BERRY, L. L. A Conceptual Model of Service Quality and Its Implications for Future Research. Jornal of Marketing, v. 49, 1985.

PATERNÒ, F. Model-Based Design and Evaluation of Interactive Applications, 2000.

PEREIRA, Marly T. Disponível em:

<http://www.esalq.usp.br/svcex/op_amazonia_2006_1.pdf>. Acesso em: Jan. 2006

PEQUINI, S. M. C. M. A evolução tecnológica da bicicleta e suas implicações ergonômicas para a máquina humana: Problemas na coluna vertebral $x$ bicicletas dos tipos `speed' e 'mountain bike`. 2000. Dissertação (Mestrado em Arquitetura e Urbanismo) - Universidade de São Paulo. 2000.

PETERSON, Robert A. Eletronic Marketing and The Consumer. California: SAGE Publications, 1997.

PIAGET, Jean. A epistemologia genética: sabedoria e ilusões da filosofia, problemas de psicologia genética. (Os pensadores). 2. ed. São Paulo: Abril Cultural, 1983. 
PORTER, M. E. Competição: estratégias competitivas essenciais. Rio de Janeiro.

PREECE, ROGERS, SHARP. Design De Interação: Além Da Interação HomemComputador. Ed. Bookman, 2005.

PROGRAMA DAS NAÇÕES UNIDAS PARA O DESENVOLVIMENTO - PNUD. SP: Reduto de ricos é $35^{\circ}$ em padrão de vida. Disponível em:

$<$ http://www.pnud.org.br/pobreza_desigualdade/reportagens/index.php?id01=1426\&l ay=pde>. Acesso em: Jan. 2006.

QUEIROZ, J. E. R. Abordagem Híbrida para a Avaliação da Usabilidade de Interfaces com o Usuário. 2001. Tese de Doutorado COPELE/CCT/UFPB. Campina Grande, Junho.

ROSENBAUM, S. A; ROHN, J. A; J. HUMBURG. A Toolkit for Strategic Usability: Results from Workshops,Panels and Serveys. In CHI 2000 Conference Procedings. New York: The Hangue:ACM. 2000.

ROSNAY, Joel de. La revolución informacional. In: RAMONET, Ignácio. Internet, el mundo que llega. Madrid: Alianza Editorial, 1998.

ROSSON, M., B; CARROLL, J. M; RODI, Con M. Case Studies for Teaching Usability Engineering SIGCSE'04. Norfolk, Virginia, USA, 2004. p. 3-7.

SADOM, Carl; HARVEY, Roger S. Human Factors for Engineers. Institution of Electrical Engineers. 2004.

SANTOS, A. R. Metodologia científica: a construção do conhecimento. 3. ed. Rio de Janeiro: DP\&A, 2000.

SABATINNI, Renato. Televisão interativa ou computador? Correio Popular, Campinas, 25 fev. 2000. Disponível em: <http://www.epub.org.br/correio/cp000225. html>. Acesso em: 09 dez 2002.

SARMET, M.M. Análise Ergonômica de Tarefas Cognitivas Complexas. 2003.

SAURO, J.; KINDLUND E. How long Should a Task Take? Identifying Specification Limits for Task Times in Usability Tests in Proceeding of the Human Computer Interaction International Conference (HCII 2005), Las Vegas, USA., 2005. 
$\therefore$

A method to standardize usability metrics into a single score Conference on Human Factors in Computing Systems archive Proceedings of the SIGCHI conference on Human factors in computing systems table of contents. Portland, Oregon, USA Session: Methods \& usability table of contents. p. $401-409,2005$.

SCHIFFMANN, Leon; KANUK, Leslie Lazar. Comportamento do Consumidor. $6^{a}$ ed. Rio de Janeiro: LTC, 2000.

SHACKEL, B. Usability: context, framework, design and evaluation. In RICHARDSON, S. (eds.). Human Factors for Informatics Usability. Cambridge University Press, Cambridge, 1991. p. 21-38.

SHNEIDERMAN, Ben. Designing the user interface: Strategies for effective Human-Computer Interaction. 3rd edition. Berkeley, California: Addison Wesley Longman, Inc., 1998.

SPINA, Edison. Tópicos de Engenharia da Confiabilidade. Disponível em: <http://www.pcs.usp.br/ pcs5751/>.

STERNBERG, R.J. A component process in analogical reasoning. Psychological Review, n. 84, p. 353-378, 1977.

Psicologia cognitiva. Porto Alegre: Artmed, 2000.

STONER, James A.; FREEMAN, R. Edward. Administração. $5^{\mathrm{a}}$ ed. Rio de Janeiro.

SUFRAMA. Disponível em: <http://www.suframa.gov.br/mzfm_industria.cfm>. Acesso em: Jan. 2006.

T INTERNATIONAL TELECOMMUNICATION UNION (ITU) Y 2011. General Principles and General Reference Model for Next Generation Networks. 2004.

TARSITANO, Paulo R. Disponível em:

<http://www.eca.usp.br/alaic/Livro\%20GTP/empatia.htm>. 
TERNINKO, John. Step-By-Step Qfd CRC Press,1997.

TURNER, J. H. Sociologia: conceitos e aplicações. São Paulo: Makron Books, 1999.

VASCONCELLOS FILHO, P. Planejamento estratégico para a retomada do desenvolvimento. Rio de Janeiro: Livros Técnicos e Científicos, 1985.

VYGOTSKI, Lev S.; LURIA, Alexander R.; LEONTIEV, Alexis N. Linguagem, desenvolvimento e aprendizagem. São Paulo: Ícone, 1998.

WAGNER III, J. A.; HOLLENBECK, J. R. Comportamento Organizacional-criando vantagem competitiva. São Paulo: 1999.

WILDMAN, D. Getting the Most from Palred-User Testing, Interections, july 1995.

WINCKLER, M. A. A. Proposta de uma Metodologia para Avaliação de Interfaces WWW. 1999. Dissertação (Mestrado em Ciência da Computação) - Programa de Pós-Graduação em Ciência da Computação, UFRGS, Porto Alegre.

ZEITHAML, V.; PARASURAMAN, A.; BERRY, L.L. A conceptual model and synthesis of research. Journal of marketing, v. 49, Fall, p. 41-50, 1985.

ZUNIGA, M. K. H.; URDAN, A. T. Satisfação do cliente com serviços de assistência técnica automobilística e lealdade dele ao fabricante. Encontro anual da associação brasileira dos programas de pós-graduação em administração. Rio de Janeiro, ANPAD, 2000. CD-ROM. 


\section{ANEXO A - Pres-test Questionnaire}

Name :

e-mail :

Age:

Profession:

Gender:

Nationality:

\section{QUESTIONS:}

How often do you use a computer?

$\{\quad$ Never
$\{\quad$ Once a month
$\{\quad$ Once a week
$\{\quad$ Every day

How long have you been using the World Wide Web (Internet)?

\{\} Never

$\{<<$ months (beginner)

\{\}$>6$ months (mediocre user)

\{\}$>$ experienced

How often do you use the World Wide Web?

$\{$ Never

$\{\quad$ Less than once a month

$\{$ Once a month

$\{$ Several times a month

$\{$ Once a week

$\{\quad$ Several times a week

$\{$ Every day

$\{\quad\}$ Several times a day or most of the day

What is the speed of your connection to the Internet?

$\{\quad$ Less than $56 \mathrm{~Kb}$
$\{\quad 36 \mathrm{~Kb}$
$\{\quad\}$ ISDN $(64 \mathrm{~Kb})$
$\{\quad$ SSL or cable modem $(144 \mathrm{~Kb}-1.5 \mathrm{Mb})$ 
$\left\{\begin{array}{l}\text { More than 1Mbps }\{\quad\} \text { Other } \\ \{\quad \text { Don't Know }\end{array}\right.$

Is the connection a permanent connection?

$\left\{\begin{array}{l}\{\text { Yes } \\ \{\quad \text { No }\end{array}\right.$

Additionally to your basic subscription, do you pay for extra services?

\{\} Yes

\{\} No

If yes, which one?

How often do you watch television?

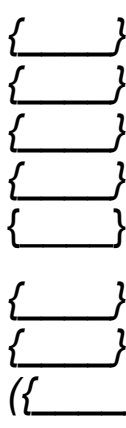

Never

Less than once a month

Once a month

Several times a month

Once a week

Several times a week

Every day: how many hours per day:

\} Several times a day or most of the day)

What type of programmes do you like/usually watch on TV? (Please tick 1 or more)

$\begin{array}{ll}\{\quad & \text { News } \\ \{\quad & \text { Documentaries } \\ \{ & \text { Sports } \\ \{ & \text { Soaps } \\ \{ & \text { Music } \\ \{\quad & \text { Reality Shows } \\ \{\quad & \text { Films } \\ \{\quad & \text { TV Games/Quiz }\end{array}$

Do you pay for a subscription channel (Canal+, satellite, cable, etc.) ?

$\{\quad\}$ Pay per month (subscription)

$\{$ Pay per view

\{_ Don't know

$\{$ Son't have

Do you have a mobile phone? (if yes please answer the following questions 11 to 15) \{\} Yes, I have

$\{$ No, I don't have

Since when do you have a mobile phone?

\{\} more than 2 years

$\{\quad 2$ to less than 1 year ago 
How often do you use your mobile phone?

$\{$ Less than once a month

$\{$ Once a month

$\{$ Several times a month

$\{$ Once a week

$\{$ Several times a week

$\{$ Every day

$\{$ Several times a day or most of the day

How long is your subscription contract for?

$\{$ More than 10 hours

$\{$ Between 5 and 10

$\{$ Between 2 and 5

$\{$ Less than two hours

\{\} Prepaid cards

What do you use your mobile phone for? (Please tick 1 or more)

$\{$ Making a phone call

$\{$ SMS

$\{$ MMS

$\{$ GPRS services, e.g. maps and distributed games

$\{$ Taking pictures

\} Games

$\{$ Listening to radio

What factors will you look for when purchasing a mobile phone? (Please tick one or more)

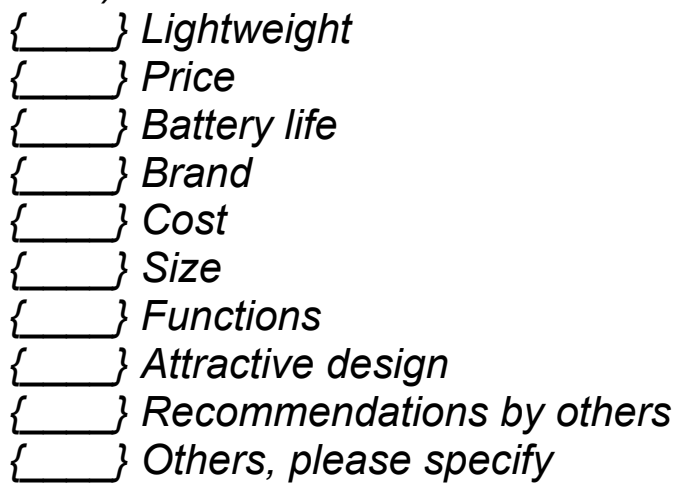




\section{ANEXO B - Pós Questionário}

\section{Service/terminal usage}

Where are you going to use/consume these digital TV services? (Multiple answers)

\{ $\}$ At home

\{\} Outdoors

\{\} At work

\{\} On train/bus

\{\} All the above

\{\} None

\{\} Other (Please specify)

What type of services would you like to consume? (Multiple answers)

\{\} Films

\{ \} Quizz shows

\{ \} General/regional news

\{\} Sports news and highlights

\{\} Documentatry/Comedy channel

\{\} TVOD

\{\} Film trailer channel

\{\} Weather information

\{\} Traffic control

\{\} Music/Radio

\{\} Online shopping/booking/reservations

\{\} Web related content

\{\} Location based information

\{ \} Cultural related (e.g. Museums, Theatres)

\{\} Travel information (airport, historic tour, ...)

\{\} Event update with/without purchase

\{\} Financial news

\{\} SMS service

\{ $\}$ Chat

\{\} Phoning All of the above

\{\} Vote

\{\} Information storage (PVR)

\{\} Photo

\{ $\}$ None

\{\} Other (Please specify)

In what type of portable device would you like to view digital TV/consume the services?
\{ \} Laptop PC
\{\} Tablet PC
\{\} PDA/Palmtop
\{ \} Mobile Phone (3G)
\{\} None
\{\} Other (Please specify) 
Are you interested in consulting your services on several terminals (your Instinct terminal while you are on the move, your PC at home, ...)

Would you want to pay your extra services from your INSTINCT terminal ?

\{ \} Yes, I would

\{ $\}$ No, I would not 


\section{ANEXO C - GENERAL CROSS-SCENARIO QUESTIONS}

\begin{tabular}{|l|l|l|}
\hline $\begin{array}{c}\text { Research goal (the users will not } \\
\text { see them) }\end{array}$ & Question for the user \\
\hline $\begin{array}{l}\text { The first questions that we ask users } \\
\text { should be "Warming up questions " } \\
\text { where the users start to appropriate } \\
\text { themselves the scenarios, for instance: }\end{array}$ & & $\begin{array}{l}\text { When do you expect that this....(service or scenario) } \\
\text { would be useful for you? }\end{array}$ \\
\hline
\end{tabular}

\section{GENERAL SERVICES ACROSS SCENARIOS:}

\section{Network :}

Can the user understand the differences between the broadcast telco networks?

What are the expectations about the differences?

How should these differences be reflected in the way the services are provided. i.e. which information would be provided to the user to change between services with different networks underlying $\mathrm{VL}$ : I don't understand the second part

Relationship between networks: p.e.

(??) launch the INSTINCT service:

When there is a MHP based service, is ther any IP based service consumed because or all the related media is delivered over carousel ?

Or can there be an MHP based service that is announced over IP and related media delivered over IP?

\section{Authentification and security}

When does the user get authenticated ?

Does he want some of his exchanges to be made secure ?

\section{Service}

How to start the portal: for Helga scenario, (without starting the TV sevice, for instance a click on the INSTINCT symbol?)
1. Differences in networks:

What are your expectation about the different networks like the one used in your mobile phone and the digital TV (broadcaster) network? Do you expect any differences in the way they work? In the price?

2. In which network is a service available:

Do you expect any differences in the type of services that would be available in each type of network?

Which relationship do you expect between all these services in different networks?

Which information do you need to know to change between a service in one network and another service in another network?
1. When to you expect that you will have to authenticate for this type of services and networks ?

2. If you wanted to choose extra services, how would you want to pay for them ? ie, would you pay them directly with your credit card ?

1. Selection of services

When do you expect to be presented with the options of the services available for you? (PUSH)

Which information would you need to make the selection of the services that are of most interest for you at a particular time?

How do you want to access to the services available for you at a particular time? (PULL)

2. Simultaneos services

Would you like to be able to receive several services simultaneously? Give as an example

Selection of a program :
1. Which information would you expect to receive to select a particular program from a list of available programs?

(How do you expect this information to be displayed?)

I would put this question in the service section. Isn't it to large as a question? the services are so 
Continuação

\begin{tabular}{|c|c|c|}
\hline & & $\begin{array}{l}\text { numerous that the presentation will be different for } \\
\text { each, no? }\end{array}$ \\
\hline $\begin{array}{l}\text { Profiles } \\
\text { (impact on the terminal/user for } \\
\text { dimensioning) } \\
\text { - Personalisation of services ? } \\
\text { - Personalisation of notifications? }\end{array}$ & $2^{J}$ & $\begin{array}{l}\text { 1. Which type of profile/s would you like to have ? } \\
\text { Would you like to have several profils (for exemple } \\
\text { depending on the place you would use your } \\
\text { terminal (at home, in the train, ;...))? } \\
\text { 2. How do you expect your profile to change the type } \\
\text { of services, notifications, and programs that would } \\
\text { be available for you? VL: Do we give examples to } \\
\text { illustrate our question? }\end{array}$ \\
\hline $\begin{array}{l}\text { Subscription } \\
\text { Which services has the end-user pre- } \\
\text { subscribed to and which has (s)he } \\
\text { subscribed on-demand? } \\
\text { User's expectations about the creation } \\
\text { of a contract vs the user subscribing to a } \\
\text { new service. }\end{array}$ & & $\begin{array}{l}\text { 1. Could you give us examples about the moment } \\
\text { when you would like to subscribe to different kind of } \\
\text { services? } \\
\text { 2. What are you expectations about the services that } \\
\text { would be covered in a contract and the services } \\
\text { paid on demand? }\end{array}$ \\
\hline $\begin{array}{l}\text { Alerts, Service Announcents, and } \\
\text { Notifications } \\
\text { Is there any difference from the user } \\
\text { point of view between: } \\
\text { - } \quad \text { Alerts } \\
\text { - } \quad \text { Service Announcement Service } \\
\text { - } \quad \text { Alert Service } \\
\text { - } \quad \text { Service Category Service } \\
\text { - } \quad \text { Service Announcement Pushed } \\
\text { - Broadcast portal } \\
\quad \text { Service Announcement Pushed } \\
\text { - } \quad \text { Portal }\end{array}$ & & $\begin{array}{l}\text { 1. When do you expect the system to inform you? } \\
\text { 2. Which types of information do you expect to } \\
\text { receive ? } \\
\text { 3. How much information do you expect to receive? } \\
\text { 4. Would you find userful to be able to have access to } \\
\text { more information about the alerts, announcents, } \\
\text { and notifications? Examples. } \\
\text { 5. Which information do you expect to be presented } \\
\text { with a hyperlink to access further information? } \\
\text { VL: do user know what an hyperlink is ?? }\end{array}$ \\
\hline SMS usage: & 5 & $\begin{array}{l}\text { 1. Could you give us an example on when SMS } \\
\text { message would be useful for the kind of situation } \\
\text { and services described in the scenario? }\end{array}$ \\
\hline Access to web & $\begin{array}{l}\mathrm{j} \\
1 \\
0\end{array}$ & $\begin{array}{l}\text { 1. Could you give us an example on when and how } \\
\text { accesing the web would be useful for the kind of } \\
\text { situation ans services described in the scenario? }\end{array}$ \\
\hline WRAP UP QUESTIONS: & & $\begin{array}{l}\text { 1. Do you have any questions about the way the } \\
\text { services presented or the scenario should be } \\
\text { used? } \\
\text { 2. Do you see advantages or disadvantages } \\
\text { compared with your current way } \\
\text { - of getting and receiving information } \\
\text { - to communicate } \\
\text { - to get and use multimedia information (e.g. } \\
\text { video, TV programas, etc) } \\
\text { 3. Do you have any problems in getting and receiving } \\
\text { information that have not been contemplated either } \\
\text { in the scenario presented to you or in the } \\
\text { conversation about it that we have had? }\end{array}$ \\
\hline
\end{tabular}


List of questions concerning John's scenario

\begin{tabular}{|c|c|c|c|c|}
\hline $\begin{array}{l}\text { Task } \\
\text { Number }\end{array}$ & Service & $\begin{array}{l}\text { Receptio } \\
n \\
\text { situation }\end{array}$ & Scenraio component & Questions \\
\hline J01 & $\begin{array}{l}\text { Portal } \\
\text { access }\end{array}$ & At home & $\begin{array}{l}\text { John connects to the } \\
\text { portal to discover the } \\
\text { whole range of provided } \\
\text { services. }\end{array}$ & $\begin{array}{l}\text { - Can you give us an example } \\
\text { of a situation when you would } \\
\text { like to receive this service? } \\
\text { - Frequency? } \\
\text { - Can you give us an example } \\
\text { of the content that you would } \\
\text { like to see in this kind of } \\
\text { service? }\end{array}$ \\
\hline J02 & $\begin{array}{l}\text { Authentific } \\
\text { ation and } \\
\text { Profile }\end{array}$ & At home & $\begin{array}{l}\text { After authenticating, he } \\
\text { can update his profile } \\
\text { and subscribe to } \\
\text { additional options }\end{array}$ & $\begin{array}{l}\text { Woulda be asked a gereral } \\
\text { question. I agree }\end{array}$ \\
\hline $\begin{array}{l}03, \\
J 04, \\
J 18\end{array}$ & $\begin{array}{l}\text { Multimedia } \\
\text { alert } \\
\text { (notification } \\
\text { ): }\end{array}$ & $\begin{array}{l}\text { At home } \\
\text { On the } \\
\text { move }\end{array}$ & $\begin{array}{l}\text { - The INSTINCT TV } \\
\text { screen gave him the } \\
\text { list of alert } \\
\text { messages he } \\
\text { received during the } \\
\text { night } \\
\text { Important } \\
\text { messages start a } \\
\text { major alert ringing } \\
\text { while the terminal is } \\
\text { in idle mode } \\
\text { He will appreciate } \\
\text { the notifications and } \\
\text { enjoy watching the } \\
\text { Tour de France } \\
\text { arrivals }\end{array}$ & $\begin{array}{l}\text { General question: } \\
\text { - Can you give us an example } \\
\text { of a situation when you would } \\
\text { like to receive this service? } \\
\text { - } \quad \text { Frequency? } \\
\text { - Can you give us an example } \\
\text { of the content that you would } \\
\text { like to see in this kind of } \\
\text { service? } \\
\text { what do you want to } \\
\text { happened (??)when the } \\
\text { system is in idle mode } \\
\text { would you like to inhibit them } \\
\text { ? In which circumstances? }\end{array}$ \\
\hline J05 & SMS & At home & $\begin{array}{l}\text { The INSTINCT TV } \\
\text { screen gave him the list } \\
\text { of the SMS he received } \\
\text { during the night }\end{array}$ & $\begin{array}{l}\text { - What is your actual usage of } \\
\text { SMS? } \\
\text { - What is your actual problems } \\
\text { of SMS? } \\
\text { Not in "general cross-scenario } \\
\text { question"? }\end{array}$ \\
\hline $\begin{array}{l}J 06, \\
\text { J13, }\end{array}$ & $\begin{array}{l}\text { Digital TV } \\
\text { on mobile } \\
\text { terminal }\end{array}$ & $\begin{array}{l}\text { At home } \\
\text { On movile }\end{array}$ & $\begin{array}{l}\text { - Thanks to the } \\
\text { provided URL in the } \\
\text { pushed alert, he has } \\
\text { access to the } \\
\text { Instinct.com rugby } \\
\text { video streaming } \\
\text { service } \\
\text { John enjoys the } \\
\text { news with } \\
\text { multimedia } \\
\text { enrichment: an } \\
\text { URL linking to } \\
\text { additional Web } \\
\text { pages related to the } \\
\text { ongoing news (not } \\
\text { sure if Multimedia } \\
\text { "multimedia }\end{array}$ & $\begin{array}{l}\text { - could you give us examples } \\
\text { on when you would like to } \\
\text { watch digital TV in a mobile } \\
\text { terminal? } \\
\text { Which programs would be } \\
\text { more interesting for you? }\end{array}$ \\
\hline
\end{tabular}




\begin{tabular}{|c|c|c|c|c|}
\hline & & & $\begin{array}{l}\text { enrichment" means } \\
\text { video. } \\
\text {-.. enjoy watching } \\
\text { the Tour de France } \\
\text { arrivals }\end{array}$ & \\
\hline J08 & $\begin{array}{ll}\text { - } & \begin{array}{l}\text { Prepaid } \\
\text { movie }\end{array}\end{array}$ & $\begin{array}{l}\text { On the } \\
\text { move }\end{array}$ & $\begin{array}{l}\text { - John connects to } \\
\text { the INSTINCT portal } \\
\text { and, after } \\
\text { authenticating, } \\
\text { orders a movie for } \\
\text { the evening }\end{array}$ & $\begin{array}{l}\text { - Can you give us an example } \\
\text { of a situation when you would } \\
\text { like to receive this service? } \\
\text { - } \quad \text { Frequency? } \\
\text { - Can you give us an example } \\
\text { of the content that you will like } \\
\text { to see in this kind of service } \\
\text { (The authentification aspect } \\
\text { would be asked in other step) }\end{array}$ \\
\hline J07, & $\begin{array}{l}\text { Broadcast } \\
\text { portal } \\
\text { Program } \\
\text { guide } \\
\text { Service } \\
\text { announcem } \\
\text { ent }\end{array}$ & $\begin{array}{l}\text { On the } \\
\text { move }\end{array}$ & $\begin{array}{l}\text { John browses the } \\
\text { broadcast portal to see } \\
\text { what services are } \\
\text { available; he has also } \\
\text { access to the TV } \\
\text { programme guide } \\
\text { He lets himself get } \\
\text { caught in the game by } \\
\text { the Orange services } \\
\text { announcement } \\
\text { broadcast on INSTINCT }\end{array}$ & $\begin{array}{l}\text { - } \quad \text { Can you give us an example } \\
\text { of a situation when you would } \\
\text { like to receive this service? } \\
\text { - } \quad \text { Frequency? } \\
\text { - } \quad \text { Can you give us an example } \\
\text { of the content that you would } \\
\text { like to see in this kind of } \\
\text { service? } \\
\text { - How to receive them? } \\
\text { - } \quad \text { How to block/filter them? } \\
\text { - } \quad \text { interaction with other services } \\
\text { - } \quad \text { click through web sites } \\
\end{array}$ \\
\hline $\begin{array}{l}J 09, J 10 \\
J 11\end{array}$ & $\begin{array}{l}\text { Weather } \\
\text { alert }\end{array}$ & $\begin{array}{l}\text { On the } \\
\text { move }\end{array}$ & $\begin{array}{l}\text { - John receives a } \\
\text { weather alert } \\
\text { - John clicks on the } \\
\text { URL provided within } \\
\text { the alert to get more } \\
\text { specific information } \\
\text { - John clicks on the } \\
\text { associated service } \\
\text { hosted by the } \\
\text { INSTINCT portal }\end{array}$ & $\begin{array}{l}\text { Examples of one content, } \\
\text { when and how it would be } \\
\text { useful }\end{array}$ \\
\hline J17 & $\begin{array}{l}\text { Traffic } \\
\text { monitoring }\end{array}$ & $\begin{array}{l}\text { On the } \\
\text { road }\end{array}$ & $\begin{array}{l}\text { Monitor on real-time the } \\
\text { traffic conditions on the } \\
\text { roads }\end{array}$ & $\begin{array}{l}\text { Examples of one content, } \\
\text { when and how it would be } \\
\text { useful }\end{array}$ \\
\hline$J 14$ & $\begin{array}{l}\text { Quizzes } \\
\text { and } \\
\text { interactive } \\
\text { pop-charts }\end{array}$ & $\begin{array}{l}\text { On the } \\
\text { move }\end{array}$ & $\begin{array}{l}\text { People participate in } \\
\text { quizzes and other } \\
\text { interactive pop-charts }\end{array}$ & $\begin{array}{l}\text { - Can you give us an example } \\
\text { of a situation when you would } \\
\text { like to receive this service? } \\
\text { - Frequency? } \\
\text { - Can you give us an example } \\
\text { of the content that you would } \\
\text { like to see in this kind of } \\
\text { service? }\end{array}$ \\
\hline J16 & Chat & $\begin{array}{l}\text { On the } \\
\text { move }\end{array}$ & & $\begin{array}{l}\text { - Can you give us an example } \\
\text { of a situation when you would } \\
\text { like to receive this service? } \\
\text { - } \quad \text { Frequency? } \\
\text { - Can you give us an example } \\
\text { of the content that you would } \\
\text { like to see in this kind of } \\
\text { service? }\end{array}$ \\
\hline
\end{tabular}


Continuação

\begin{tabular}{|c|c|c|c|c|}
\hline $\begin{array}{l}\text { J19, } \\
\text { J20 }\end{array}$ & $\begin{array}{l}\text { Download } \\
\text { of the news } \\
\text { paper } \\
\text { subscribe } \\
\text { Vs } \\
\text { Download } \\
\text { of a } \\
\text { magazine } \\
\text { on- demand }\end{array}$ & $\begin{array}{l}\text { At the } \\
\text { camp site }\end{array}$ & $\begin{array}{l}\text { - He will also be } \\
\text { happy to download } \\
\text { his favourite sports } \\
\text { daily paper every } \\
\text { morning } \\
\text { - Not to mention his } \\
\text { clever idea to } \\
\text { download on- } \\
\text { demand a "people" } \\
\text { magazine }\end{array}$ & $\begin{array}{l}\text { - Can you give us an example } \\
\text { of a situation when you would } \\
\text { like to receive this service? In } \\
\text { which circumstances they } \\
\text { expect to download on } \\
\text { demand or to subscribe? } \\
\text { - Frequency? } \\
\text { - Can you give us an example } \\
\text { of the content that you would } \\
\text { like to see in this kind of } \\
\text { service? } \\
\text { - How do you expect the } \\
\text { process for downloading a } \\
\text { newspaper to be? } \\
\text { (do the users understand } \\
\text { the process of downloading vs } \\
\text { streaming? }\end{array}$ \\
\hline
\end{tabular}


List of questions concerning Helga' scenario

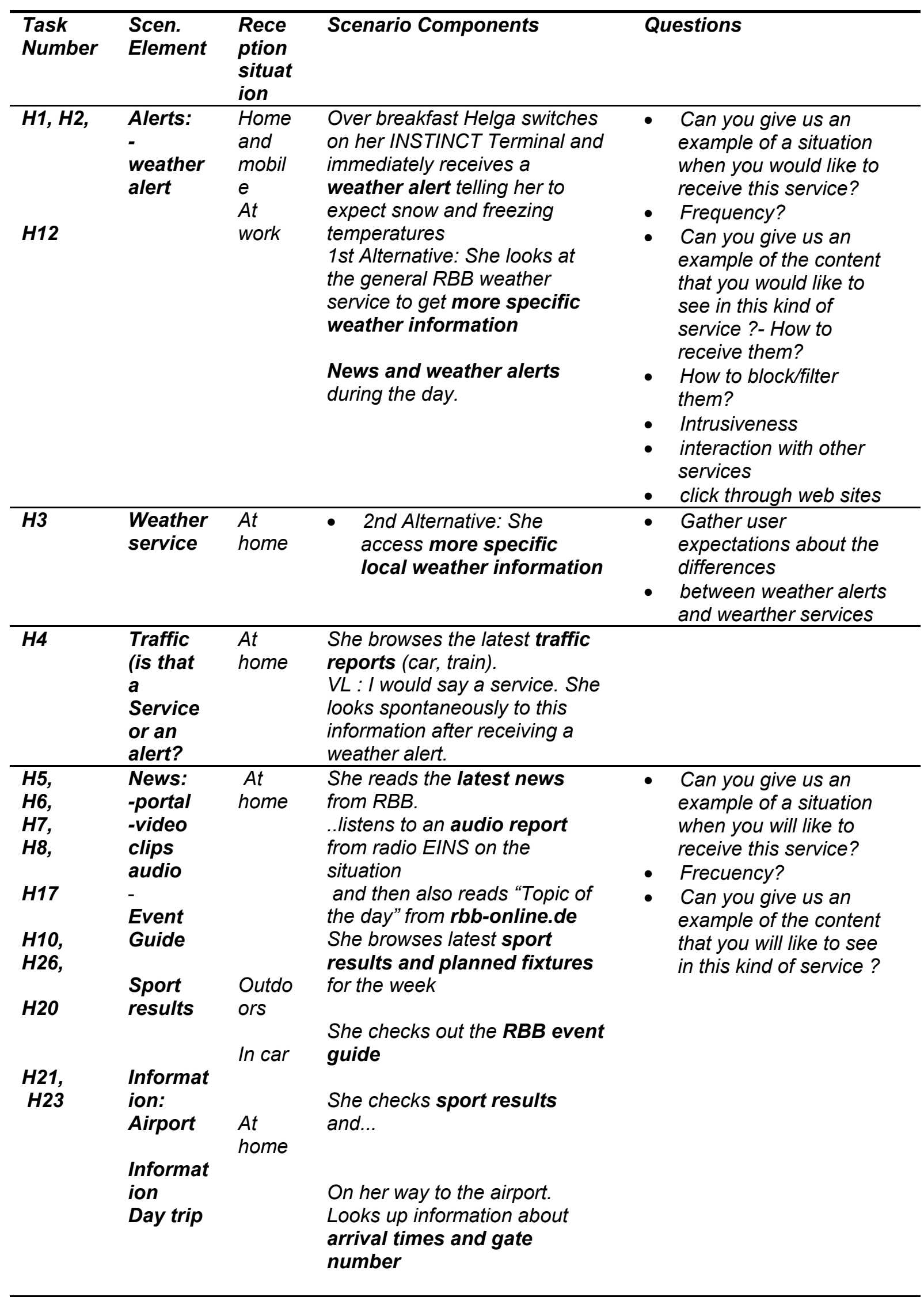


Continuação

\begin{tabular}{|c|c|c|c|c|}
\hline & & & $\begin{array}{l}\text { Wants to go on an excursion } \\
\text { with her friend. She looks up } \\
\text { day trip tips from RBB and } \\
\text { reads about ice skating in } \\
\text { Brandenburg... } \\
\text {... sees where it is on the } \\
\text { section of map supplied }\end{array}$ & \\
\hline $\mathrm{H} 28$ & Sport & $\begin{array}{l}\text { Outdo } \\
\text { ors }\end{array}$ & \multicolumn{2}{|c|}{$\begin{array}{l}\text { Looks up more information about sport on the sport } \\
\text { programme's website }\end{array}$} \\
\hline$H 9$ & $\begin{array}{l}\text { News: } \\
\text { Voting } \\
\text { Event } \\
\text { Guide: } \\
\text { competi } \\
\text { tion }\end{array}$ & $\begin{array}{l}\text { At } \\
\text { home }\end{array}$ & $\begin{array}{l}\text { She takes part in the vote: Are } \\
\text { the students right to continue } \\
\text { their strike action? } \\
\text { She enters a competition to } \\
\text { win tickets for the concert. }\end{array}$ & $\begin{array}{l}\text { - Can you give us an } \\
\text { example of a situation } \\
\text { when you will like to } \\
\text { receive this service? } \\
\text { - Frecuency? } \\
\text { - Can you give us an } \\
\text { example of the content } \\
\text { that you will like to see } \\
\text { in this kind of service? }\end{array}$ \\
\hline$H 11$ & $\begin{array}{l}\text { News } \\
\text { Sport: } \\
\text { partici- } \\
\text { in fan } \\
\text { forum }\end{array}$ & $\begin{array}{l}\text { At } \\
\text { home }\end{array}$ & $\begin{array}{l}\text { She comments on Saturday's } \\
\text { match in the fan forum. }\end{array}$ & $\begin{array}{l}\text { Can you give us an } \\
\text { example of a situation } \\
\text { when you will like to } \\
\text { receive this service? } \\
\text { - } \quad \text { Frecuency? } \\
\text { - Can you give us an } \\
\text { example of the content } \\
\text { that you will like to see } \\
\text { in this kind of service? }\end{array}$ \\
\hline H13 & $\begin{array}{l}\text { TV: } \\
\text { selectio } \\
n \text { of } \\
\text { progra } \\
\text { ms }\end{array}$ & $\begin{array}{l}\text { On } \\
\text { train }\end{array}$ & $\begin{array}{l}\text { Back on the train. After } \\
\text { browsing the TV EPG... }\end{array}$ & $\begin{array}{l}\text { Can you give us an } \\
\text { example of a situation } \\
\text { when you will like to } \\
\text { receive this service? } \\
\text { - Frecuency? } \\
\text { - Can you give us an } \\
\text { example of the content } \\
\text { that you will like to see } \\
\text { in this kind of service? }\end{array}$ \\
\hline $\begin{array}{l}H 22, \\
H 27\end{array}$ & $\begin{array}{l}\text { Video } \\
\text { clip } \\
\text { watchin } \\
\text { g } \\
\text { Day trip, } \\
\text { sport, } \\
\text { news } \\
\text { Vs. } \\
\text { TV: } \\
\text { watchin } \\
\text { g }\end{array}$ & $\begin{array}{l}\text { On } \\
\text { train } \\
\text { At } \\
\text { home }\end{array}$ & $\begin{array}{l}\text { She watches some video } \\
\text { footage of the latest strike } \\
\text { action... } \\
\text {...and watches a video of the } \\
\text { highlights } \\
\text { watches a video about it (day } \\
\text { trip) } \\
\text { vs. } \\
\text {..she watches a soap on her } \\
\text { terminal on the way home. }\end{array}$ & $\begin{array}{l}\text { - Can you give us an } \\
\text { example of a situation } \\
\text { when you would like to } \\
\text { watch tv and/or watch a } \\
\text { video clip? } \\
\text { - Are the sitions for one or } \\
\text { another different? ??? } \\
\text { - Frequency? } \\
\text { - Can you give us an } \\
\text { example of the content } \\
\text { that you would like to } \\
\text { see in this kind of } \\
\text { service? }\end{array}$ \\
\hline H15 & $\begin{array}{l}\text { TV: } \\
\text { recordin } \\
g\end{array}$ & $\begin{array}{l}\text { On } \\
\text { train }\end{array}$ & $\begin{array}{l}\text { She watches a soap on her } \\
\text { terminal on the way home. She } \\
\text { uses } \\
\text { PVR (personal video recorder) } \\
\text { functionality. }\end{array}$ & $\begin{array}{l}\text { - Can you give us an } \\
\text { example of a situation } \\
\text { when you will like to to } \\
\text { record program? }\end{array}$ \\
\hline H16 & Phone & $\begin{array}{l}\text { At } \\
\text { home }\end{array}$ & $\begin{array}{l}\text { She phones her friend and } \\
\text { arranges to meet her later in } \\
\text { the week }\end{array}$ & $\begin{array}{l}\text { - Question about the } \\
\text { intrusiveness and } \\
\text { relationship between the }\end{array}$ \\
\hline
\end{tabular}




\begin{tabular}{|c|c|c|c|c|}
\hline & & & & $\begin{array}{l}\text { services and the "phone } \\
\text { basic" usage } \\
\text { - What do you expect to } \\
\text { happen when making a } \\
\text { phone in your Instinct } \\
\text { terminal? What about } \\
\text { the other services that } \\
\text { you may be using? }\end{array}$ \\
\hline $\begin{array}{l}\text { H19, } \\
\text { H25 }\end{array}$ & $\begin{array}{l}\text { Event } \\
\text { Guide: } \\
\text { buying, } \\
\text { Ecomm } \\
\text { erce } \\
\text { Restaur } \\
\text { ant } \\
\text { Guide: } \\
\text { booking }\end{array}$ & $\begin{array}{l}\text { At } \\
\text { home }\end{array}$ & $\begin{array}{l}\text { She orders tickets for the } \\
\text { cinema } \\
\text { then makes reservation for a } \\
\text { restaurant by phone call }\end{array}$ & $\begin{array}{l}\text { Can you give us an } \\
\text { example of a situation } \\
\text { when you would like to } \\
\text { receive this service? } \\
\text { - } \quad \text { Frequency? } \\
\text { Can you give us an } \\
\text { example of the content } \\
\text { that you will like to see } \\
\text { in this kind of service }\end{array}$ \\
\hline $\begin{array}{l}H 24, \\
H 29, \\
H 30\end{array}$ & $\begin{array}{l}\text { Context } \\
\text { based } \\
\text { informat } \\
\text { ion: } \\
\text { Restaur } \\
\text { ant } \\
\text { Guide } \\
\text { Historic } \\
\text { Tour }\end{array}$ & $\begin{array}{l}\text { Outdo } \\
\text { ors }\end{array}$ & $\begin{array}{l}\text { She checks restaurant } \\
\text { recommendations for the } \\
\text { area... } \\
\text { Walking along route of the } \\
\text { Berlin Wall. They receive } \\
\text { location based text } \\
\text { information about the history } \\
\text { of the wall... } \\
\text {...and links to more in-depth } \\
\text { information. }\end{array}$ & $\begin{array}{l}\text { - Can you give us an } \\
\text { example of a situation } \\
\text { when you would like to } \\
\text { receive this service? } \\
\text { - Frequency? } \\
\text { - Can you give us an } \\
\text { example of the content } \\
\text { that you will like to see } \\
\text { in this kind of service } \\
\text { Would you like to be } \\
\text { able to receive } \\
\text { specialised local } \\
\text { information related to } \\
\text { your location? }\end{array}$ \\
\hline
\end{tabular}




\section{ANEXO D - QUESTIONÁRIO WEB}

A seguir, tem-se um exemplo das duas versões do questionário: na FIGURA 36 temos o questionário em sua primeira versão, e na FIGURA 37 a versão modificada, que já incorpora o feedback dos entrevistados.

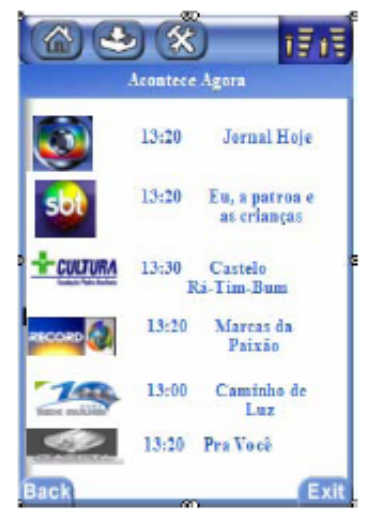
Ao acessar a opção 'Acontece Agora', o usuário visualiza a programação das diversas emissoras naquele momento, a tela que aparece é a mostrada ao lado. Esta possibilidade de serviço para você seria :
- Muito útil e interessante, usaria sempre
u Útil, usaria com regularidade
a Razoavelmente útil
- Eventualmente útil para ser usada esporadicamente
- Irrelevante, não usaria esse tipo de serviço.

Figura 36 - Versão original do Questionário Web
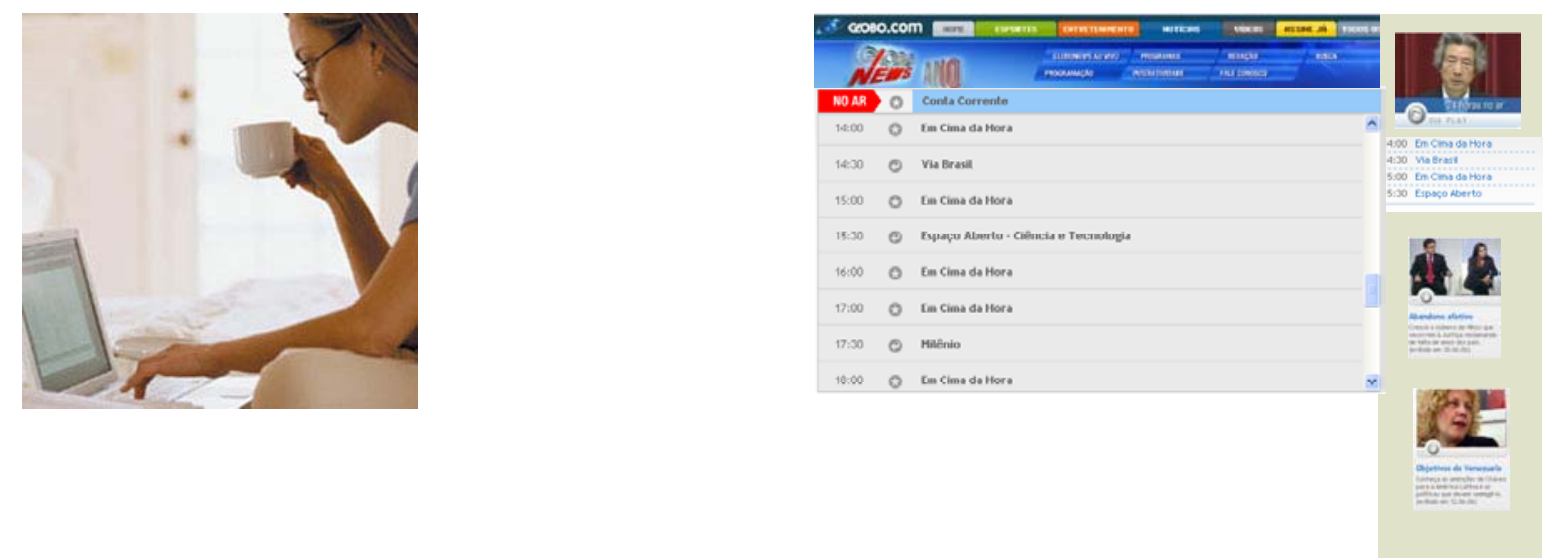

Figura 37- Acesso à programação de Noticias $^{4}$ guia de TV

Figura - Versão modificada do Questionário Web , incorporando feedback dos usuários

Qual o grau de importância o Guia de TV tem para você?

$\square$ Muito útil e interessante, usaria sempre.

$\square$ Útil , usaria com regularidade.

Razoavelmente útil.

$\square$ Eventualmente útil para ser usada esporadicamente.

$\square$ Irrelevante, não usaria esse tipo de serviço.

${ }^{4}$ Fonte: http://www.medical.siemens.com/ 
Outros? Quais?

- (...) "Seria interessante se fosse possível escolher mais de uma opção"

Esta sugestão se refere a questões com múltiplas respostas possíveis, como no exemplo da figura a seguir (extraído do questionário original):

Que tipo de informação você acha que seria interessante receber nessa opção de serviço:

$\square$ condições das principais rodovias e vias de acesso.

$\square$ pontos de congestionamento.

$\square$ mapas

$\square$ rotas alternativas

$\square$ indicações de serviços nas mediações (hospitais, postos, restaurantes)

$\square$ Outros, especificar

Figura 38- Questão com múltiplas respostas possíveis

- (...) "Achei as telas desorganizas, figuras sem clareza”

Esta sugestão se refere a páginas como a representada na Figura 39, a seguir.

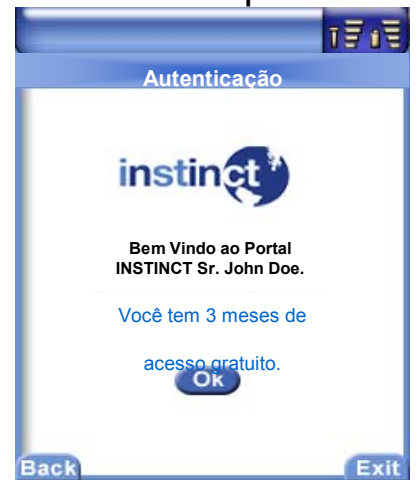

Figura 39- Tela inicial do portal Instinct

- (...) "Muita navegação para pouco conteúdo"

- $\quad$ (...) "Os alertas devem ser configuráveis e seu uso restrito, caso contrário, criará antipatia por parte do usuário"

- (...) "O questionário é bom, mas poderia ter mais espaços para sugestões" 
Estas sugestões se referem a questões no formato representado na Figura a seguir.

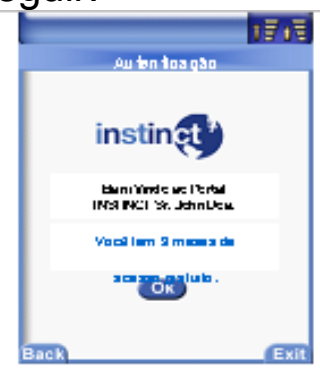

A tela inicial do portal INSTINCT é:

$\square \quad$ Bastante agradável e atrativa

- Agradável, com informações adequadas

ㅁ Adequada, mas poderia ser mais atrativa visualmente

- Agradável, mas poderia conter mais informações

$\square \quad$ Inadequada e pouco atrativa

Os serviços que à prinć́pio são mostrados,em sua opinião são interessantes de serem acessados a partir de que tipo de equipamento?
$\square \quad$ celular.
$\square \quad \mathrm{TV}$,
L Lap top
․ $\mathrm{PC}$
ㅁ Palm top

Figura 40- Questionário via Web

Outras sugestões relevantes:

- (...) "Não visualizei nenhuma tela de "entrada" de dados para os serviços, temos somente telas de resultados"

- (...) "Outro ponto importante é que há mais de uma questão por página isso acaba se tornando muito cansativo de ler"

- (...) "Acho muito importante existir em todas as perguntas a opção "Outros? Quais?" Porque particularmente, eu sou exigente na minha resposta e quero representá-la de maneira fiel"

- (..) "A navegação deveria ser mais amigável e a maneira como os serviços estão disponíveis também. Isso faz com que perdemos a vontade de preenchermos o questionário... Faltam ilustrações mais criativas" 